\title{
Diversity of gobioid fishes in the late middle Miocene of northern Moldova, Eastern Paratethys - part I: an extinct clade of Lesueurigobius look-alikes
}

\author{
Bettina Reichenbacher ${ }^{1,2}(\mathbb{0})$. Alexander F. Bannikov ${ }^{3}$
}

Received: 18 March 2021 / Accepted: 15 June 2021 / Published online: 26 August 2021

(c) The Author(s) 2021

\begin{abstract}
Studies of otoliths suggest that Gobioidei, which are among the most species-rich groups of modern-day vertebrates, were prominent elements of late middle Miocene (early Sarmatian sensu lato) fish faunas in Europe and Western Asia. However, few complete skeletons have come to light. Here, we report an assemblage of six marine gobiid species, based on skeletons preserved with otoliths in situ, from the lower Volhynian (lower Sarmatian s.1.) of Karpov Yar, Naslavcea, northern Moldova (Eastern Paratethys). Previously only one of these species had been reported from the Central Paratethys, based on its otoliths alone. Five new species representing four new genera are described: $†$ Katyagobius prikryli gen. et sp. nov., Pseudolesueurigobius manfredi gen. et sp. nov., †Sarmatigobius compactus gen. et sp. nov., $†$ Yarigobius decoratus gen. et sp. nov., and $\dagger Y$. naslavcensis gen. et sp. nov. All six species share the following set of characters, suggesting that they represent a monophyletic clade: $27-29$ vertebrae (of which 10 are abdominal); spines of first dorsal fin distally filamentous; second dorsal fin with spine and 14-16 soft rays; anal fin with spine and 13-15 soft rays; caudal fin longish-to-lanceolate; otoliths (sagittae) with rounded, trapezoid-to-squarish shape. Their skeletal features suggest that they are closely related to Lesueurigobius Whitley, 1950, but the otoliths preserved in situ do not support such a classification. The new fossils most likely represent a stem lineage of the European Aphia lineage, and indicate that the diversity of gobiid lineages 12 million years ago differed clearly from that observed today.
\end{abstract}

Keywords Gobiidae $\cdot$ Aphia-lineage $\cdot$ Fish fossils $\cdot$ New taxa $\cdot$ Otoliths in situ $\cdot$ Eastern Paratethys $\cdot$ Moldova $\cdot$ Serravallian

\section{Introduction}

The middle Miocene of Europe and Asia was a time of palaeogeographic reorganizations and fluctuating environments, due to the orogeny and uplift of the

Handling Editor: Mike Reich.

Bettina Reichenbacher

b.reichenbacher@lmu.de

Alexander F. Bannikov

aban@paleo.ru

1 Department of Earth and Environmental Sciences, LudwigMaximilians-Universität München, Richard-Wagner Straße 10, 80333 Munich, Germany

2 GeoBio-Center, Ludwig-Maximilians-Universität München, Munich, Germany

3 Borissiak Paleontological Institute, Russian Academy of Sciences, Profsoyuznaya ul. 123, Moscow 117647, Russia
Alpine-Himalayan mountain chains and global climate change (Zachos et al. 2001). These changes also affected the marine environments of the large inland seas that covered Central and Eastern Europe and Western Asia at that time, i.e., the Central Paratethys (Pannonian Basin) and the Eastern Paratethys (Black Sea or Euxinian Basin) (Popov et al. 2004; Harzhauser and Piller 2007; Kováč et al. 2017). The late middle Miocene (middle to late Serravallian) is a particularly interesting time span. Time-equivalent chronostratigraphic stages in the Central Paratethys are the late Badenian and the Sarmatian (sensu stricto), and in the Eastern Paratethys the Konkian and the early Sarmatian sensu lato, i.e., the Volhynian (Fig. 1). During the latest Badenian (c. 12.6 Ma), the Central Paratethys became isolated due to a global fall in sea level and the final stage of the Carpathian orogeny (Piller and Harzhauser 2005; Kováč et al. 2017; Fig. 2). In both the Central and Eastern Paratethys, the beginning of the Sarmatian (s.s.) and Volhynian stages, respectively, was characterized by a transgression, during 


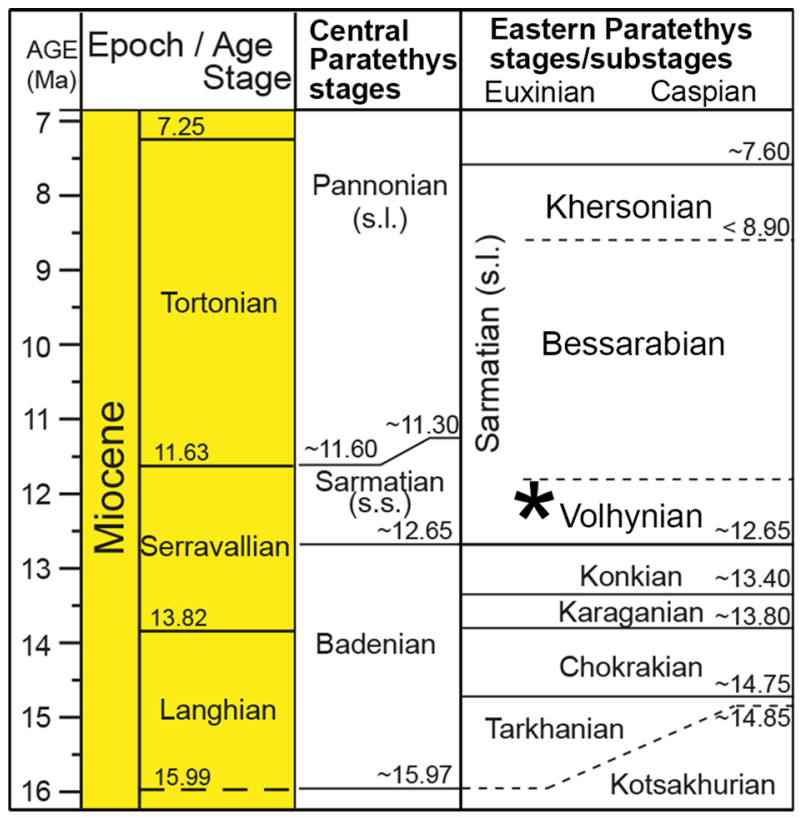

Fig. 1 Late Miocene chronostratigraphic framework in the Central and Eastern Paratethys and correlation to the Global Time Scale. The stratigraphic age of the study site Karpov Yar in Naslavcea, Moldova, is indicated with a star. Modified from Raffi et al. (2020)

which continental lowland regions were flooded and transformed into marginal marine and eventually fully marine areas (Pisera 1996; Piller and Harzhauser 2005).

Fossil remains of teleost fishes are relatively common in the Sarmatian (s.s.)/Volhynian of the Central/Eastern Paratethys, and have received considerable scholarly attention. In the Central Paratethys, mostly isolated otoliths have been used to reconstruct the Sarmatian (s.s.) fish fauna (Weiler 1943, 1949; Rado 1968; Brzobohatý and Stancu 1974; Strashimirov 1984, 1985a, b; Schwarzhans et al. 2015; Reichenbacher et al. 2019), while relatively few studies have described articulated skeletal material (Baykina 2013; Přikryl et al. 2016; Schwarzhans et al. 2017a, b, c, d, e). In the Eastern Paratethys, articulated skeletal material has been an important source of information on the Volhynian teleost fauna (e.g., Ionko 1954; Bogatshev 1955; Switchenska 1959a, b, 1973; Bannikov 1986, 1989a, b, 1990, 1992, 1998, 2006, 2009; Carnevale et al. 2006; Bannikov et al. 2016), but isolated otoliths have also been studied (Pobedina 1954; Pobedina et al. 1956; Paghida 1962; Paghida-Trelea et al. 1967; Djafarova 2006).

'Gobies' - small, mostly benthic fishes of the suborder Gobioidei of the order Gobiiformes (sensu Thacker et al. 2015) - were an important component of the Central Paratethys fish fauna during the Sarmatian (s.s.), both in terms of species numbers and abundance, and it appears that many endemic species were among them (Schwarzhans et al. 2015, 2017a; Reichenbacher et al. 2019). The time-equivalent
Eastern Paratethys fish fauna also contains gobioid fishes, but very little data are available for them (see Carnevale et al. 2006; Bannikov 2009).

The present study aims to fill this gap on the basis of wellpreserved, articulated skeletons of gobioid fishes, which have been left unidentified or in open nomenclature in previous works (Ionko 1954; Bannikov 2009, 2010, 2017, 2018). These specimens come from the lower Volhynian deposits at Karpov Yar, in the vicinity of the township Naslavcea in northern Moldova (western sector of the Eastern Paratethys; Fig. 3). Because the results of our study reveal an unexpected diversity of goby species, we have chosen to split the presentation of the data into three parts, of which this is the first. Six species, including five new ones, representing four new genera are described. All share the following unique features: large numbers of rays in the second dorsal fin (14-16) and anal fin (13-15) and, where preserved, a caudal fin of longish to lanceolate shape. They resemble the present-day European genus Lesueurigobius Whitley, 1950, but, based on their otoliths preserved in situ, they cannot belong to this genus.

\section{Geological setting}

In the Karpov Yar ravine in northern Moldova (Fig. 3a), the lower Volhynian strata unconformably overlie Upper Cretaceous conglomerates and cherts (Ionko 1954; Yakubovskaya 1955), and the clays at their base contain an abundance of terrestrial plant leaves. Clearly, these are deposits of coastal swamps, as evidenced by the discovery of a spade-footed toad there in 2007 (Skutschas and Bannikov 2009). Above follow diatomites and marls (Fig. 3b) of a lagoonal environment, as indicated by several thin layers with evidence of mass mortality of fishes; the fish finds reported here are limited to these layers. Further up in the outcrop of the Karpov Yar ravine, these layers disappear, and the early Volhynian marine transgression is readily traceable. Karpov Yar has long been known for its well-preserved teleost fish fauna, and many specimens are preserved with otoliths in situ (Ionko 1954; Switchenska 1973; Bannikov 1986, 1989a, b, 1990, 1992, 1998, 2006, 2009; Baykina and Schwarzhans 2017; Popov 2017). Furthermore, mollusc species are widely distributed throughout the sequence. According to Roşca (2008) they include the bivalve Loripes niveus (von Eichwald, 1830) [= Microloripes dentatus Defrance, 1823; see Studencka (1986)] and the gastropods Terebralia lignitarum (von Eichwald, 1830), Clavatula doderleini (M. Hoernes, 1856) and Tritonalia striata (von Eichwald, 1853) [=Ocinebrina striata (von Eichwald, 1853); see Landau et al. 2013]. Some of these species (M. dentatus, $C$. doderleini) are also distributed in the early Sarmatian of the Central Paratethys (Filipescu et al. 2014). 


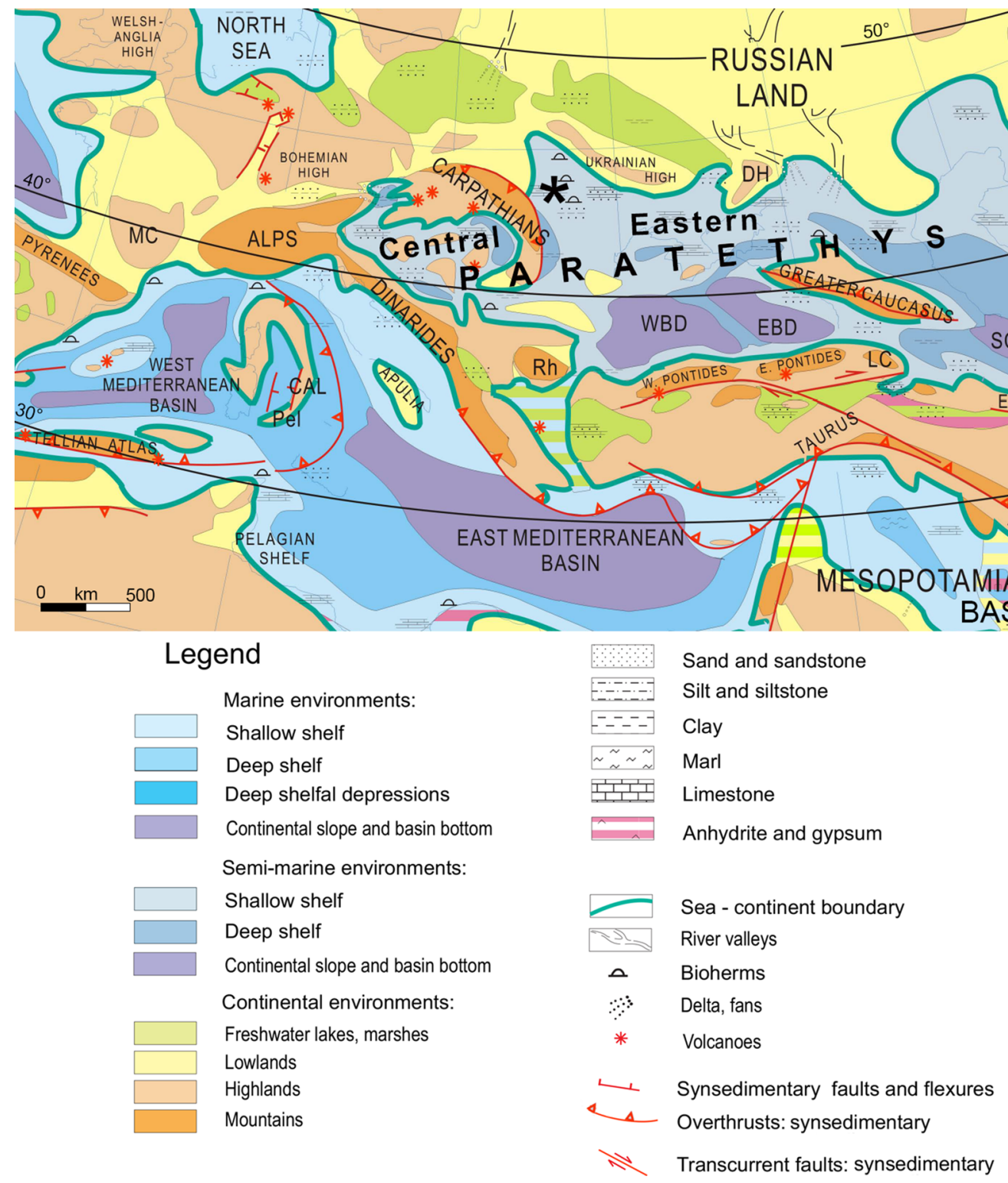

Fig. 2 Palaeogeographic map of Central Europe and Western Asia during the late middle Miocene (12-11 Ma), depicting the open marine Mediterranean Basin and the semi-closed inland sea of the

\section{Previously described fish fauna from Karpov Yar}

A relatively rich and quite distinctive marine fish fauna is known from the lower Volhynian of the Karpov Yar locality, including Moldavichthys switshenskae Baykina and Schwarzhans, 2017 (Clupeidae); 'Prolebias' sp. (Cyprinodontidae); Atherina suchovi Switchenska, 1973 (Atherinidae); Nerophis zapfei Bachmayer, 1980; gen. et sp. indet. (Syngnathidae); 'Scorpaena' sp. (Scorpaenidae); Lates gregarius Bannikov, 1992 (Latidae); Morone ionkoi Bannikov, 1993 (Moronidae); Sparus brusinai (Gorjanović-Kramberger, 1882)

Central and Eastern Paratethys. The location of the study site Karpov Yar in Naslavcea, Moldova, is indicated with a star. Map after Popov et al. (2004: map 7)

(Sparidae); Naslavcea fundata (Bannikov, 1990) (Centracanthidae); Mullus moldavicus Switchenska, 1959a (Mullidae); Polydactylus frivolus Bannikov, 1989b (Polynemidae); Mugil acer Switchenska, 1959b (Mugilidae); Symphodus salvus Bannikov, 1986 (Labridae); Clinitrachoides gratus (Bannikov, 1989a) (Clinidae) and Pleuronectiformes fam., gen. et sp. indet. (e.g., Bannikov 2009, 2019). Unlike many marine ichthyofaunas of different ages, in which clupeids typically predominate strongly, in the Karpov Yar fish fauna the most commonly collected species is the silverside Atherina suchovi. The herring Moldavichthys switshenskae is almost as abundant as the gobioid fishes; and specimens of 


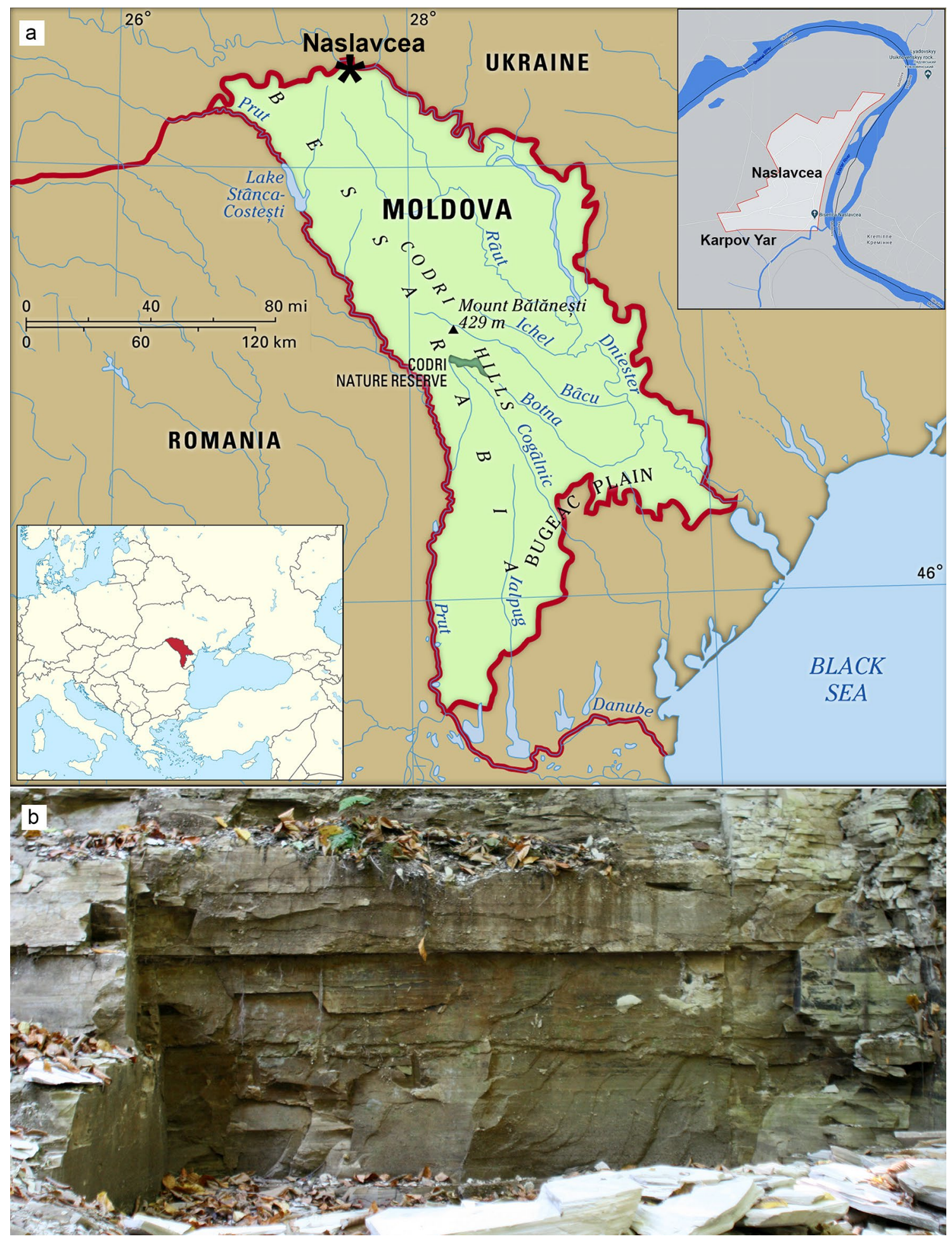

Fig. 3 a Geographic map of Moldova and location of Naslavcea (star); inset at lower left depicts location of Moldova (in red) in relation to Central Europa and Western Asia; inset at upper right is a close-up of the township Naslavcea with the location of the Kar- pov Yar outcrop (sources: https://cdn.britannica.com; Wikipedia). b Photo of the laminated diatomites at the Karpov Yar outcrop (photo by A.F.B.) 
the seabream Sparus brusinai, the mullet species Mugil acer and the wrasse Symphodus salvus are also quite common. The two rarest fish species are a pipefish (Nerophis zapfei) and a scorpionfish ('Scorpaena' sp.), which are represented by a single find each.

Volhynian fishes of the Eastern Paratethys basin have been recorded in various localities in the North Caucasus, the Crimea, Azerbaijan, Moldova and the Ukraine (see Bannikov 2009, 2019). However, only the Tsurevsky assemblage (SW Russia, Pshekha River) (Carnevale et al. 2006; Bannikov 2009, 2019) is nearly as well known as the coeval Karpov Yar assemblage. Although these two fish assemblages belong to the same marine basin, i.e., the Eastern Paratethys, their faunal compositions at the species level are completely different, and very few genera (Mullus, Mugil and perhaps Scorpaena) are shared between them. Bottom-dwellers are far less well represented in the Tsurevsky locality than at Karpov Yar, and the only gobioid fishes identified there to date are two specimens of Pomatoschistus sp. (Carnevale et al. 2006: fig. 12; Bannikov 2009: pl. 10, fig. 3). Apparently, the connection between the North Caucasian and Moldovan basins in the early Volhynian was interrupted, and the two fish localities were formed under different conditions (Bannikov 2009, 2019).

\section{Materials and methods}

\section{Fossil material}

Articulated skeletons of nine fossil specimens are included in this study. One specimen had no otoliths; in all others one or both saccular otoliths (= sagitta, sagittae) were preserved in situ, and in five specimens the utricular otolith(s) (=lapillus, lapilli) were also present. One species is represented by two skeleton-based specimens, all others are represented by one specimen each. With one exception, all specimens were preserved as part (indicated with ' $a$ ', head to the right) and counterpart ('b', head to the left). The skeletal-based material is deposited in the Borissiak Palaeontological Institute of the Russian Academy of Sciences in Moscow, under the inventory numbers PIN 5274/21a-b, PIN 5274/35a-b, PIN 5274/36a-b, PIN 5274/38a-b, PIN 5274/75a-b, PIN 5274/76a-b, PIN 1306/71, PIN 1306/72a-b, PIN 1306/81ab. The corresponding otoliths are kept in the Bavarian State Collection for Palaeontology and Geology (SNSB-BSPG) in Munich, Germany, under the inventory number SNSBBSPG 2021 XI.

\section{Comparative material}

Specimens of two extant species of Lesueurigobius were studied from the collections of the National Museum in
Prague, Czech Republic (NMP) and the Zoological State Collection in Munich, Germany (ZSM-PIS). This material comprises eight specimens of L. friesii (Malm, 1874) (NMP6V 146223-146230) from the Northeast Atlantic off Galicia (Spain), and two specimens of $L$. sanzi (de Buen, 1918) (ZSM-PIS-035529_1,_4) from the Southeast Atlantic off Angola. For study results, see Appendix Table.

\section{Methods}

Morphometric, meristic and osteological characters of the fossil skeletons and the morphology of the otoliths were analysed and photographed under a Leica M165 FC stereomicroscope equipped with a digital camera (Leica DC 200). The comparative material of Lesueurigobius was X-rayed in a Faxitron Ultra Focus cabinet (max. spatial resolution: 100 $\mathrm{lp} / \mathrm{mm}$ ) at the Zoological State Collection in Munich, and the $\mathrm{X}$-ray images served as the basis for measurements, counts and osteological studies. Methods of measurement followed those given in previous publications on extant gobiid fishes (e.g., Miller 2004; Liu et al. 2009; Iglésias et al. 2021) and were applied (as far as possible) to both the fossil specimens and the comparative material; all measurements were recorded to the nearest $0.1 \mathrm{~mm}$ using ImageJ (Schneider et al. 2012) and were standardized based on the standard length of the measured fish. For raw measurements of the fossils, see Supplementary Data 1, and for raw data of the extant comparative material, see Supplementary Data 2.

Counts of vertebrae include the terminal centrum; counts of rays in the second dorsal and anal fins encompass every discernible ray; the pterygiophore formula of the first dorsal fin follows Birdsong et al. (1988). Topographic terms refer to the natural anatomical location of the structure concerned, even if this is rotated or otherwise displaced in the specimen. Figures were prepared using Adobe Photoshop CS6 (13.0.6).

Otoliths were carefully extracted from the fossil specimens and kept separately. Otolith terminologies are shown in Fig. 4 and follow Schwarzhans (2014) and Lombarte et al. (2018) for the sagitta, and Assis $(2000,2005)$ for the lapillus. Otolith measurements were done with ImageJ; the maximum length and height of the sagittae, and the maximum width and height of the lapilli were taken by drawing a rectangle that fully enclosed the outermost elements of the respective sagitta (Fig. 4b) or lapillus (Fig. 4d); the maximum otolith thickness was measured in the same way.

Extinct taxa are marked with a dagger $(\dagger)$ preceding their name.

Abbreviations used in the text. $\alpha$, inclination angle of sulcus; D1, first dorsal fin; D2, second dorsal fin; SL, standard length. 


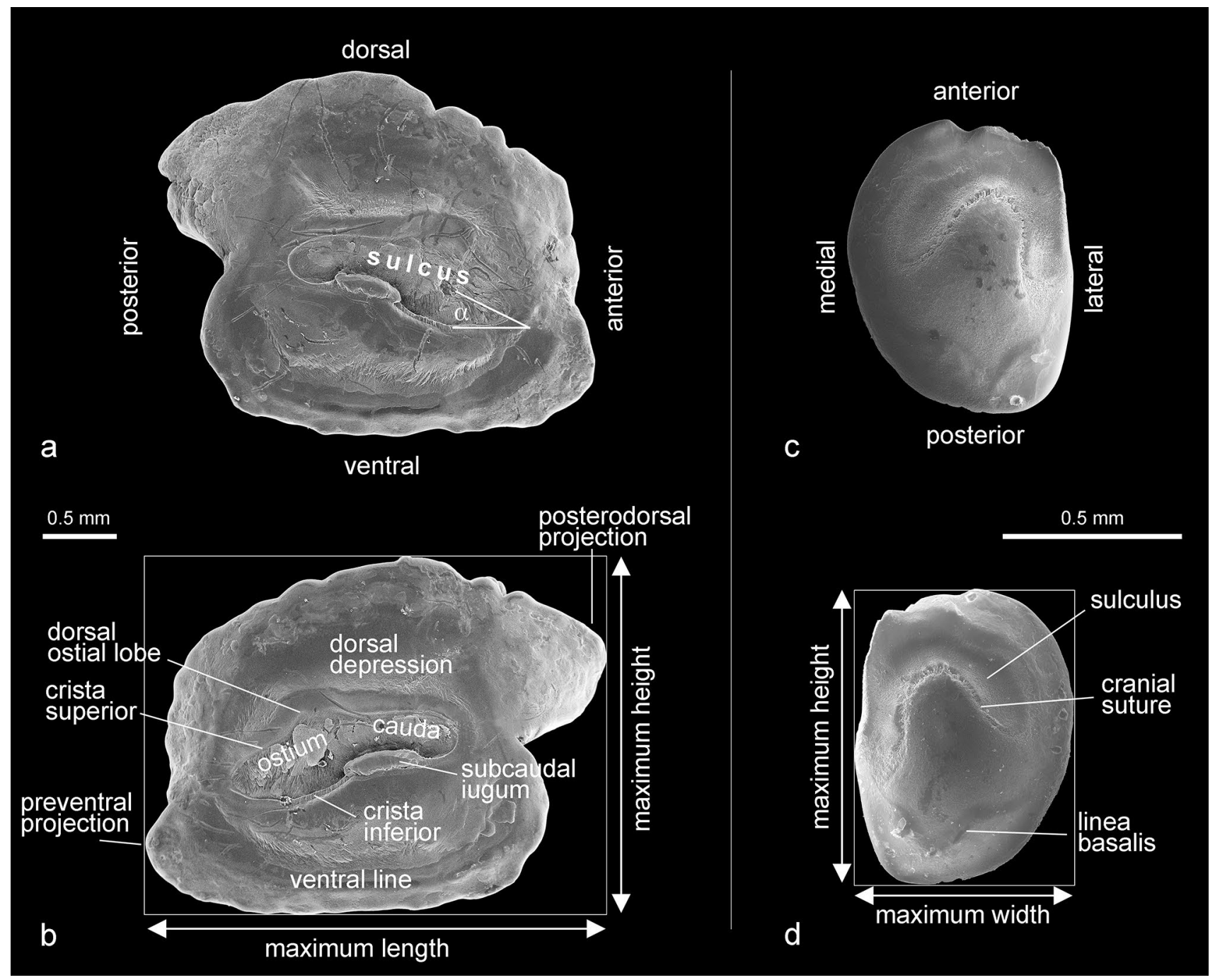

Fig. 4 Left and right sagitta in medial view $(\mathbf{a}, \mathbf{b})$, and left and right lapillus in ventral view (c, d), based on a specimen of Gobius niger (59.3 mm SL; NMP6V 146077). The shown terminology and meas-

Institutional abbreviations. AMS, Australian Museum Sydney, Australia; IRSNB, Royal Institute of Natural Sciences Belgium; NHMW, Natural History Museum, Vienna, Austria; NMP, National Museum Prague, Prague, Czech Republic; PIN, Borissiak Palaeontological Institute of the Russian Academy of Sciences, Moscow, Russia; SMF, Senckenberg Institute, Frankfurt am Main, Germany; SNSB-ZSM, Bavarian State Collection of Zoology, Munich, Germany.

\section{Systematic palaeontology}

Infraclass Teleostei Müller, 1845 sensu Arratia (1999) Order Gobiiformes Günther, 1880 sensu Betancur-R et al. (2017) urements for the sagitta follow Schwarzhans $(2014 ; \alpha$ indicates sulcus inclination angle), Gierl et al. (2018) and Lombarte et al. (2018); those for the lapillus are according to Assis (2000, 2005)

Suborder Gobioidei Jordan and Evermann, 1896 sensu Thacker et al. (2015)

Family Gobiidae Cuvier, 1816 sensu Nelson et al. (2016)

Genus $\uparrow$ Katyagobius gen. nov.

Type species. $\dagger$ Katyagobius prikryli gen. et sp. nov. (Figs. 5a, 6a, 7a, 8a, 9a, 10a).

Other species. $†$ Katyagobius sp. (Figs. $6 \mathrm{~b}, 7 \mathrm{~b}, 9 \mathrm{~b}-\mathrm{d}, 10 \mathrm{~b}, \mathrm{c}$, Supplementary Data 3 ) from the same locality.

Etymology. The generic epithet honours the goby expert Dr. Ekaterina (= Katya) D. Vasil'eva (Zoological Museum, Moscow, Russia) for her important work on the osteology 


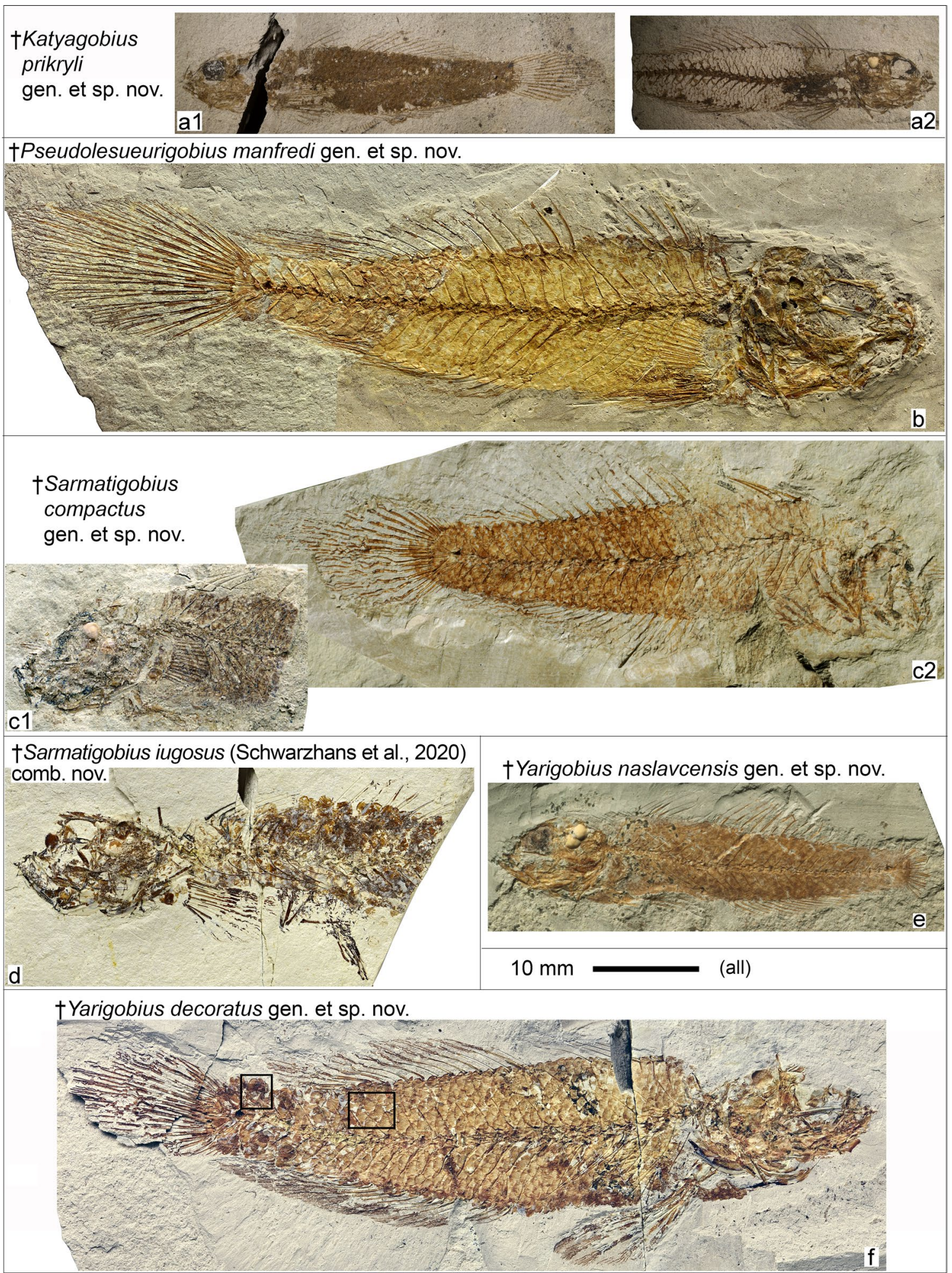

Fig. 5 Holotypes of the five new goby species (a-c, e, f) and skeleton-type of $\dagger$ Sarmatigobius iugosus (Schwarzhans, Brzobohatý and Radwańska, 2020) comb. nov. (d) from Karpov Yar, near Naslavcea, northern Moldova. a PIN 5274/21b (a1), PIN 5274/21a with left sagitta in situ (a2). b PIN 1306/72a-b (composite image based on part and counterpart). c PIN 5274/36b with right and left sagittae and right lapillus in situ (c1), PIN 5274/36a (c2). d PIN 5274/38b with right sagitta in situ. e PIN 1306/71 with right and left sagittae in situ. f PIN 5274/76a, boxes on the caudal peduncle and flank refer to scales shown at a higher magnification in Fig. 11d1, d2 

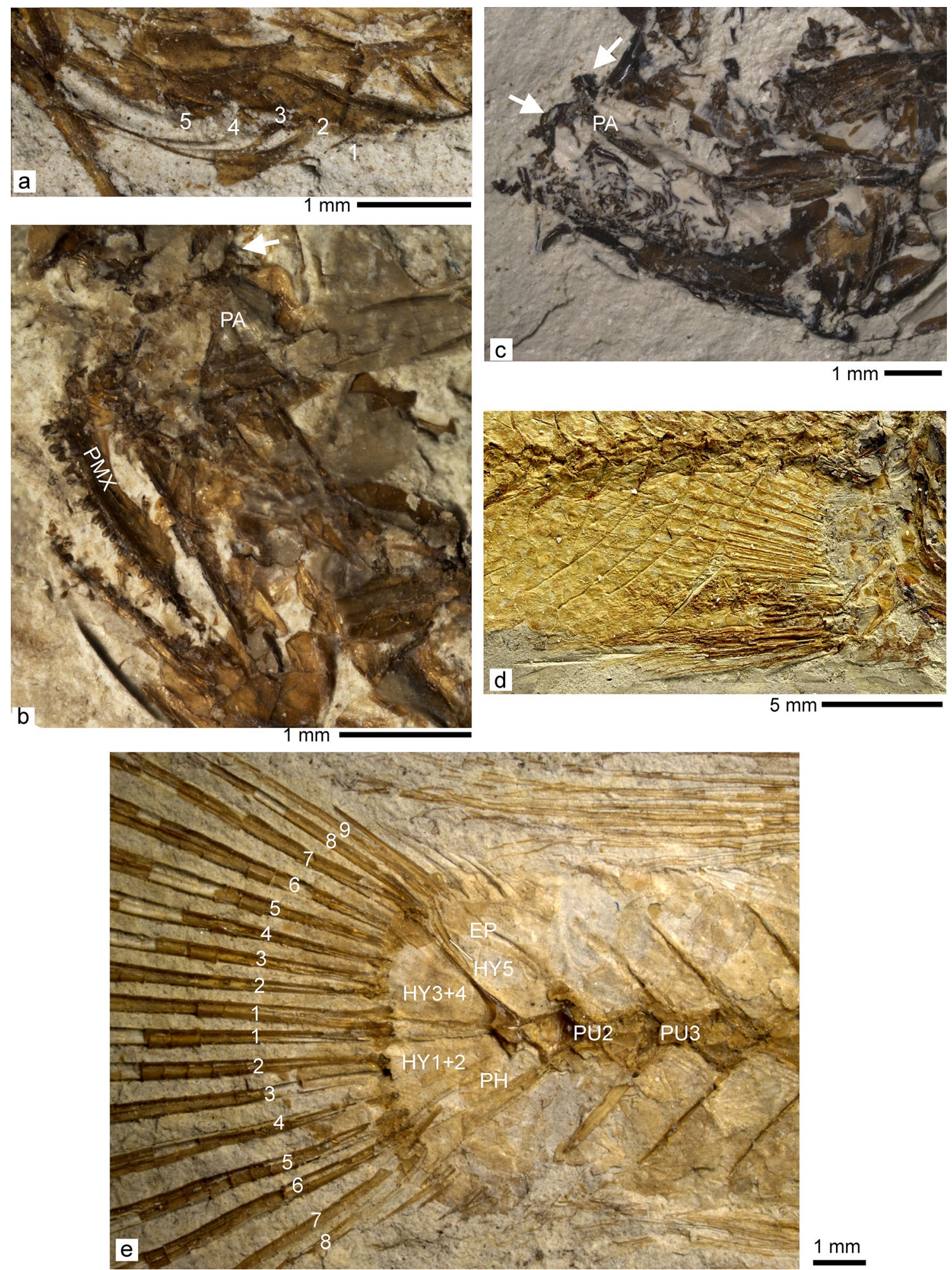

$1 \mathrm{~mm}$

and diversity of the gobiid fishes from the Caspian Basin. Gender masculine.
LSID ZooBank. This new genus is registered under urn:Isid: zoobank.org:act:15083225-AFA5-468D-A90917411888AE4A.

Stratigraphic range. Lower Sarmatian. 
४Fig. 6 a Hyoid bar with five branchiostegal rays of $\dagger$ Katyagobius prikryli gen. et sp. nov. (holotype, PIN 5274/21a). b Jaw bones of Katyagobius sp. (PIN 5274/35a). Note the T-shaped palatine (PA, with ethmoid process indicated by the arrow), the left premaxilla (PMX) with a moderately developed postmaxillary process, and jaw teeth of various sizes. c Jaw bones of $\dagger$ Sarmatigobius ingosus (Schwarzhans, Brzobohatý and Radwańska, 2020) comb. nov. (PIN 5274/38), with T-shaped palatine (PA, arrows indicate maxillary and ethmoid process) and conical jaw teeth of different sizes. d, e †Pseudolesueurigobius manfredi gen. et sp. nov. (holotype, PIN 1306/72a) showing (d) pelvic fins located close to each other and (e) caudal skeleton showing two preural vertebrae (PU2, PU3), two broad hypural plates $(\mathrm{HY} 1+2, \mathrm{HY} 3+4)$, a short, rod-shaped hypural plate 5 , a single, long epural (EP) and a long parhypural ( $\mathrm{PH})$; numbers on caudal rays indicate segmented rays in the upper and lower lobe, respectively

Diagnosis. $\dagger$ Katyagobius gen. nov. is a small gobiid fish; SL between 31 and $36.2 \mathrm{~mm}$. Head moderately large (23.9$25.7 \% \mathrm{SL}$ ); body probably laterally compressed (as preserved in lateral view); body depth 17.7-18.5\% SL at origin of D1; anal fin inserted one to two vertebrae behind D2; caudal peduncle moderately long (20.2-21.0\% SL); caudal fin lanceolate and approximately as long as head (24.9$27.4 \% \mathrm{SL}$ ); length of abdominal part of vertebral column approx. $53 \%$ of that of caudal part. Number of vertebrae $28(10+18)$; D1 with six relatively robust, distally filamentous spines; distance between spines V and VI is $4.5-4.7 \%$ SL; pterygiophore formula 3-22110; D2 with relatively long spine (8.4-9.9\% SL) that tapers to a distal filament, and 15 segmented rays; anal fin with moderately long spine (4.8-6.3\% SL) and 14 segmented rays. Pectoral fin with 10 to 13 rays. Pelvic fin length $16.1-17.1 \% \mathrm{SL}$; pelvic fin with relatively long spine (6.0-6.5\% SL, 57-66\% of adjacent ray) and five rays; end of pelvic rays distant from anal fin origin. Caudal fin with 16-17 segmented rays, nine rays in the upper lobe. Relatively dense cover of ctenoid (in type species) or cycloid scales (in $†$ Katyagobius sp.) on body.

Otoliths-Sagitta slightly trapezoid, rounded; ventral portion of posterior margin bulged; sulcus 'shoe-sole' shaped, moderately inclined $\left(\alpha=9.6-15.7^{\circ}\right)$, with well-developed crista inferior along cauda. Lapillus rectangular-to-ovate in type species, otherwise ovate; relatively thick (LH/LT 2.5$2.7)$; in lateral view with straight to weakly convex ventral side, symmetrically convex dorsal side, and slightly tapering anterior tip.

Differential diagnosis. With respect to the presence of a longish lanceolate caudal fin, large numbers of rays in the D2 and anal fin, and general proportions of head and body, the extant genus Lesueurigobius Whitley, 1950 and the three other new fossil genera described here, i.e., $† P s e u$ dolesueurigobius gen. nov., †Sarmatigobius gen. nov., and $†$ Yarigobius gen. nov. are phenotypically similar to $\dagger$ Katyagobius gen. nov. (see Table 1 for data on the fossils and Appendix Table for data on Lesueurigobius). With regard to the skeletal characters, the relatively robust D1 spines (Fig. 7a) and the comparatively long pelvic-fin spine (6.0-6.5\% SL vs. 3.8-5.2\% SL [no data for $†$ Sarmatigobius gen. nov.]) are characteristic for $\dagger$ Katyagobius gen. nov. Furthermore, the sagitta and lapillus of $\dagger$ Katyagobius gen. nov. are each unique in shape (Figs. $9 \mathrm{a}-\mathrm{d}, 10 \mathrm{a}-\mathrm{c}$ ). Seen in lateral view, the lapillus has a distinctive contour and is relatively thicker than any of the other lapilli studied here (ratio lapillus height/thickness $2.5-2.7$ vs. 3.0-3.3 [no data for Pseudolesueurigobius gen. nov.]). Furthermore, $†$ Katyagobius gen. nov. can be distinguished from both Lesueurigobius and $\dagger$ Pseudolesueurigobius gen. nov. by its total number of vertebrae (28 vs. 27); from both $\dagger$ Pseudolesueurigobius gen. nov. and $\uparrow$ Sarmatigobius gen. nov. by the relatively longer distance between D1-spines V and VI (4.5-4.7\% SL vs. 3.0$3.4 \% \mathrm{SL})$, a slightly longer caudal peduncle (20.2-21.0\% SL vs. 18.0-18.5\% SL), and a relatively shorter caudal fin (24.9-27.4\% SL vs. 32.6-33.8\% SL); from $†$ Sarmatigobius gen. nov. also by the more posterior insertion of the anal fin (one to two vertebrae behind D2 vs. opposite); and from $\dagger$ Yarigobius gen. nov. by a smaller body depth at the origin of D1 (17.7-18.5\% SL vs. 21.4-21.7\% SL), slightly shorter pelvic fins (16.1-17.1\% SL vs. 20.9-22.9\% SL), and a D1 pterygiophore formula starting with $3-2 \ldots$ (vs. 3-1...).

$\dagger$ Katyagobius prikryli gen. et sp. nov. Figures 5a, 6a, 7a, 8a, 9a, 10a; Table 1

Type material. Holotype, PIN 5274/21a, b; 31.0 mm SL; part and counterpart in lateral view; part complete except for the posterior part of caudal peduncle and caudal fin, with left sagitta and right lapillus preserved in situ; counterpart complete except for the pectoral girdle and posterior part of head.

Type locality and age. Karpov Yar, Naslavcea, northern Moldova; lower Sarmatian.

Etymology. In honour of Dr. Tomáš Přikryl (Charles University and Czech Academy of Sciences, Prague, Czech Republic), for his excellent work on Oligocene-Miocene fish species and diversity.

LSID ZooBank. This new species is registered under urn:1sid:zoobank.org:act:E5BE05B1-EC88 -4086-83B1-F020F6BDF28E.

Diagnosis. SL $31 \mathrm{~mm}$; head moderately large (23.9\% SL); caudal peduncle relatively long $(21.0 \% \mathrm{SL})$; caudal fin lanceolate and slightly longer than head $(27.4 \%$ SL); spine I of D1 robust and moderately long (87\% of length of spine II); D2 with relatively long spine $(8.4 \% \mathrm{SL})$ and moderately 
†Katyagobius prikryli gen. et sp. nov.

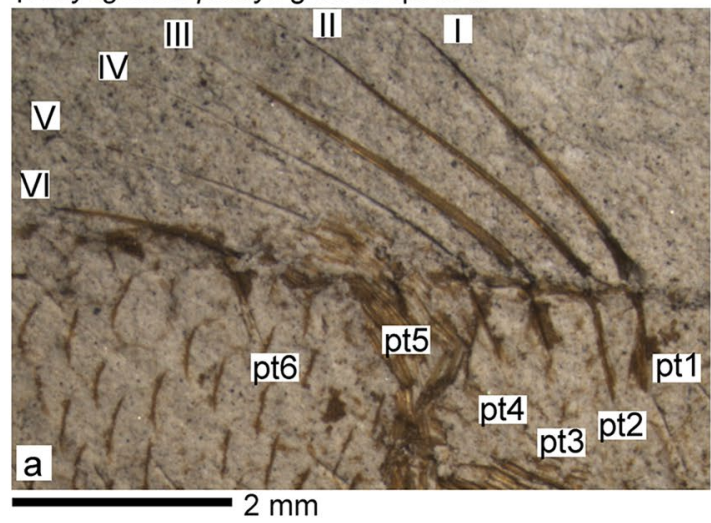

†Pseudolesueurigobius manfredi gen. et sp. nov.

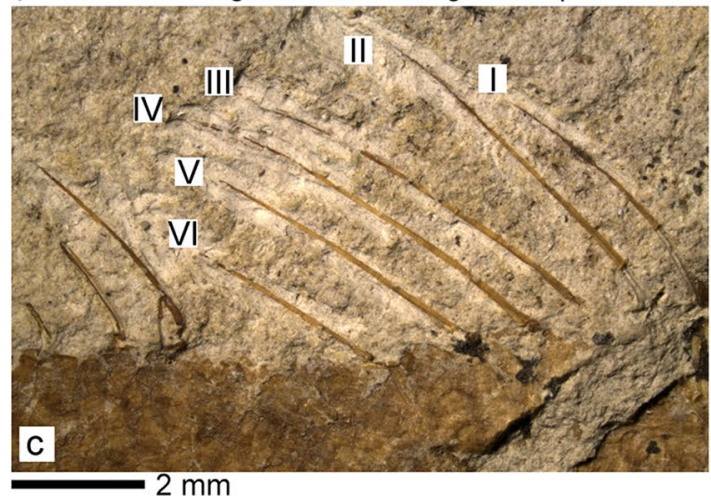

†Sarmatigobius compactus gen. et sp. nov.

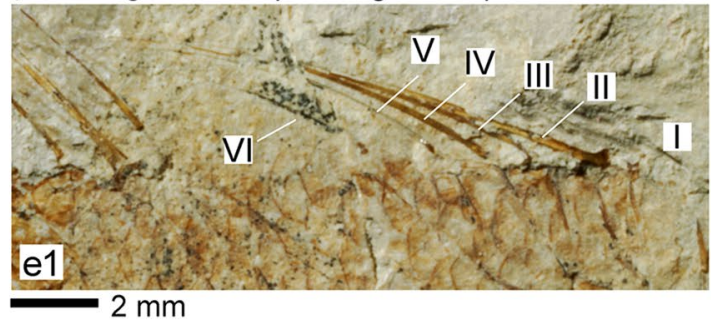

†Yarigobius decoratus gen. et sp. nov.

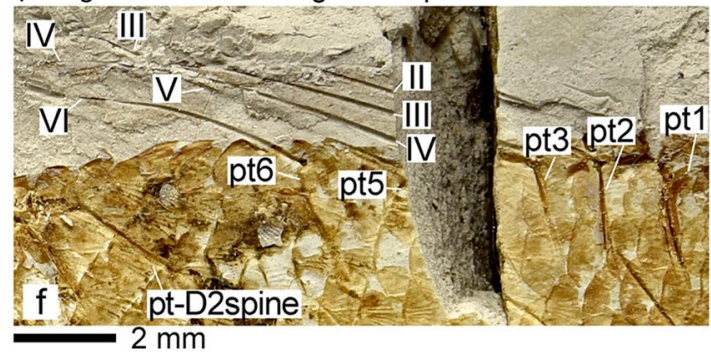

Fig. 7 Configuration of the D1-spines in the goby species from Karpov Yar, near Naslavcea, northern Moldova. a holotype, PIN 5274/21. b PIN 5274/35a. c paratype, PIN 1306/81. d PIN 5274/38. e holotype

long filament; anal-fin spine moderately long (4.8\% SL); pelvic-fin spine robust and relatively long $(6.5 \% \mathrm{SL}, 66 \%$ of adjacent ray); relatively dense cover of ctenoid flank scales with thickened posterior margins; about 32 scales in
†Katyagobius sp.

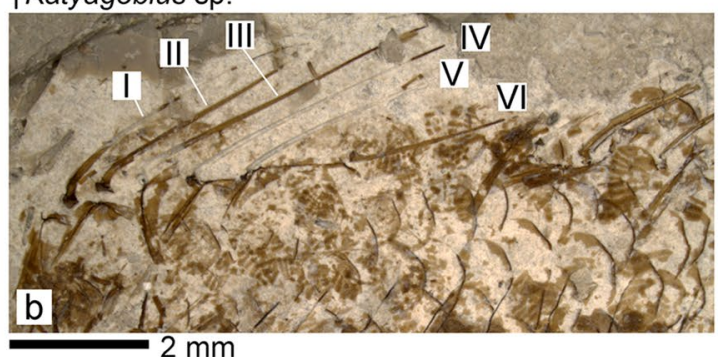

†Sarmatigobius iugosus (Schwarzhans et al., 2020) comb. nov.

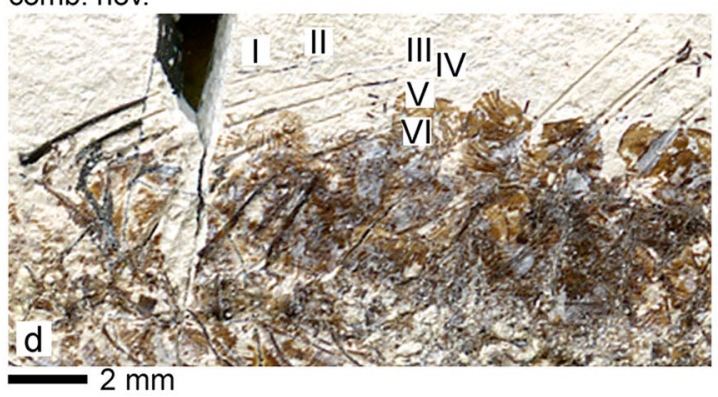

†Sarmatigobius compactus gen. et sp. nov.

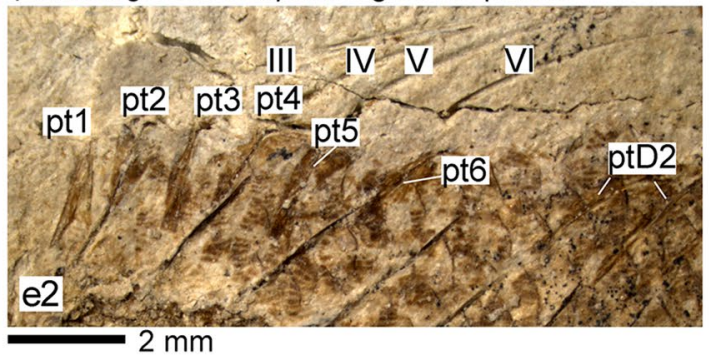

†Yarigobius naslavcensis gen. et sp. nov.

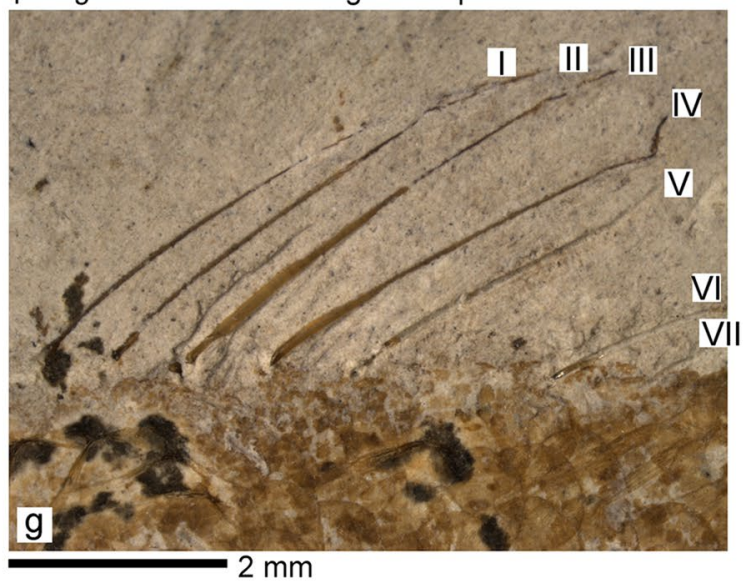

part (e1) and counterpart (e2), PIN 5274/36. f holotype, PIN 5274/76. g holotype, PIN 1306/71. Roman numerals refer to individual spines; pt1, pt2...refer to pterygiophore of respective spine

the longitudinal row. Other characters as described in the generic diagnosis. 


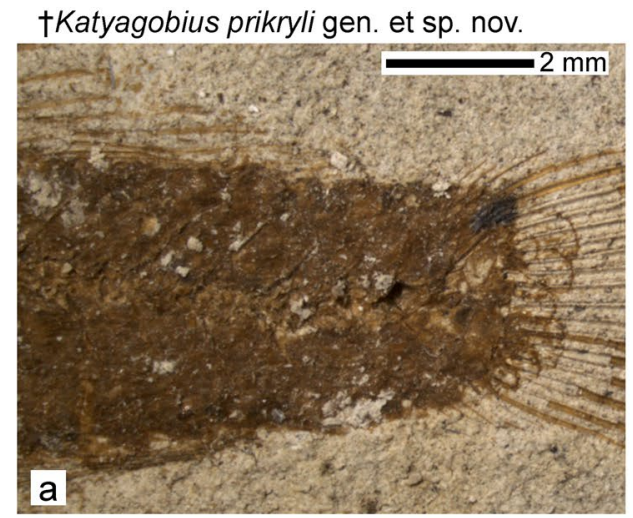

†Sarmatigobius compactus gen. et sp. nov.
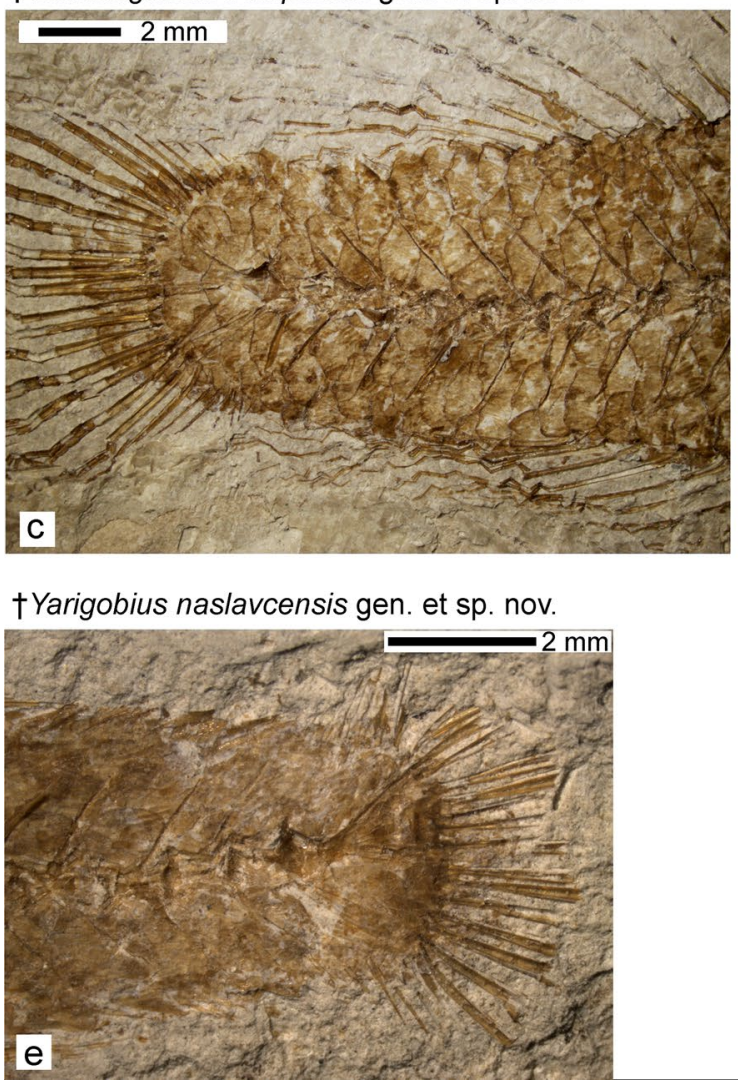

Fig. 8 Caudal peduncle and posterior extension of the second dorsal fin rays and anal fin rays in the studied new goby species from Karpov Yar, near Naslavcea, Moldova (close-ups of holotypes of the

General description. Relatively small gobiid fish of $31 \mathrm{~mm}$ SL (Fig. 5a). Body slender, tapering posteriorly, probably laterally compressed (as preserved in lateral view); head of moderate size (23.9\% SL); D2 slightly in front of insertion of anal fin; relatively long caudal peduncle $(21.0 \% \mathrm{SL})$; caudal fin lanceolate and slightly longer than head (27.4\% SL). For further body proportions and meristic counts, see Table 1 .
†Pseudolesueurigobius manfredi gen. et sp. nov.

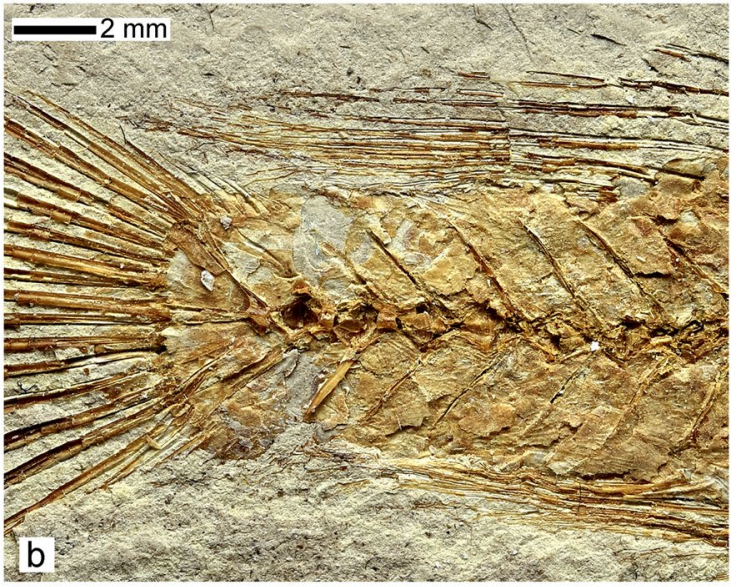

†Yarigobius decoratus gen. et sp. nov.

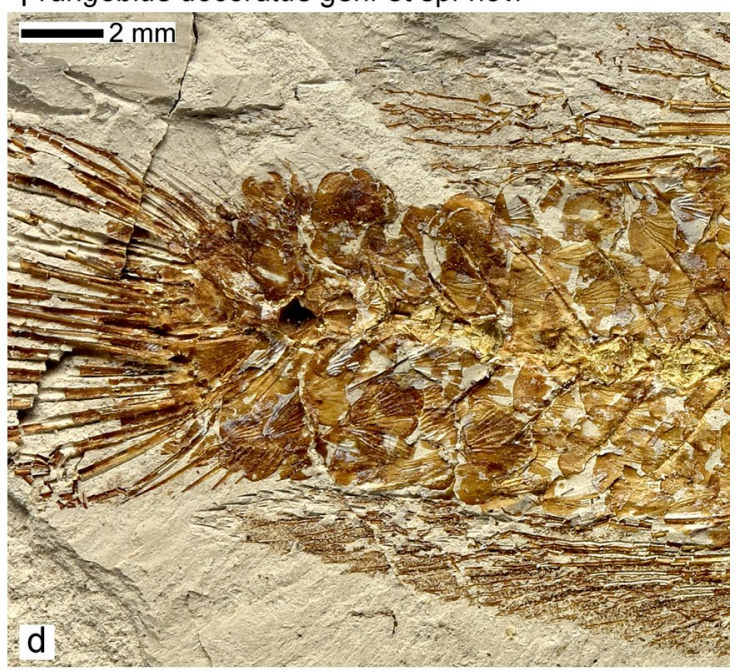

new species shown in Fig. 5). a PIN 5274/21. b PIN 1306/72. c PIN 5274/36. d PIN 5274/76. e PIN 1306/71

Neurocranium-The neurocranium is preserved in lateral view; it is relatively deep, but most of its bones are not well preserved. The eyes are relatively large $(6.8 \% \mathrm{SL})$. The frontal bones are long and oriented obliquely to the body axis over the orbit, narrow between the orbits and broad posteriorly. The parasphenoid is a straight, thin rod with a broad posterior portion; the vomer is recognizable, but its shape is not clear. The ethmoid region is short. Whether scales are present on the head is unclear. 


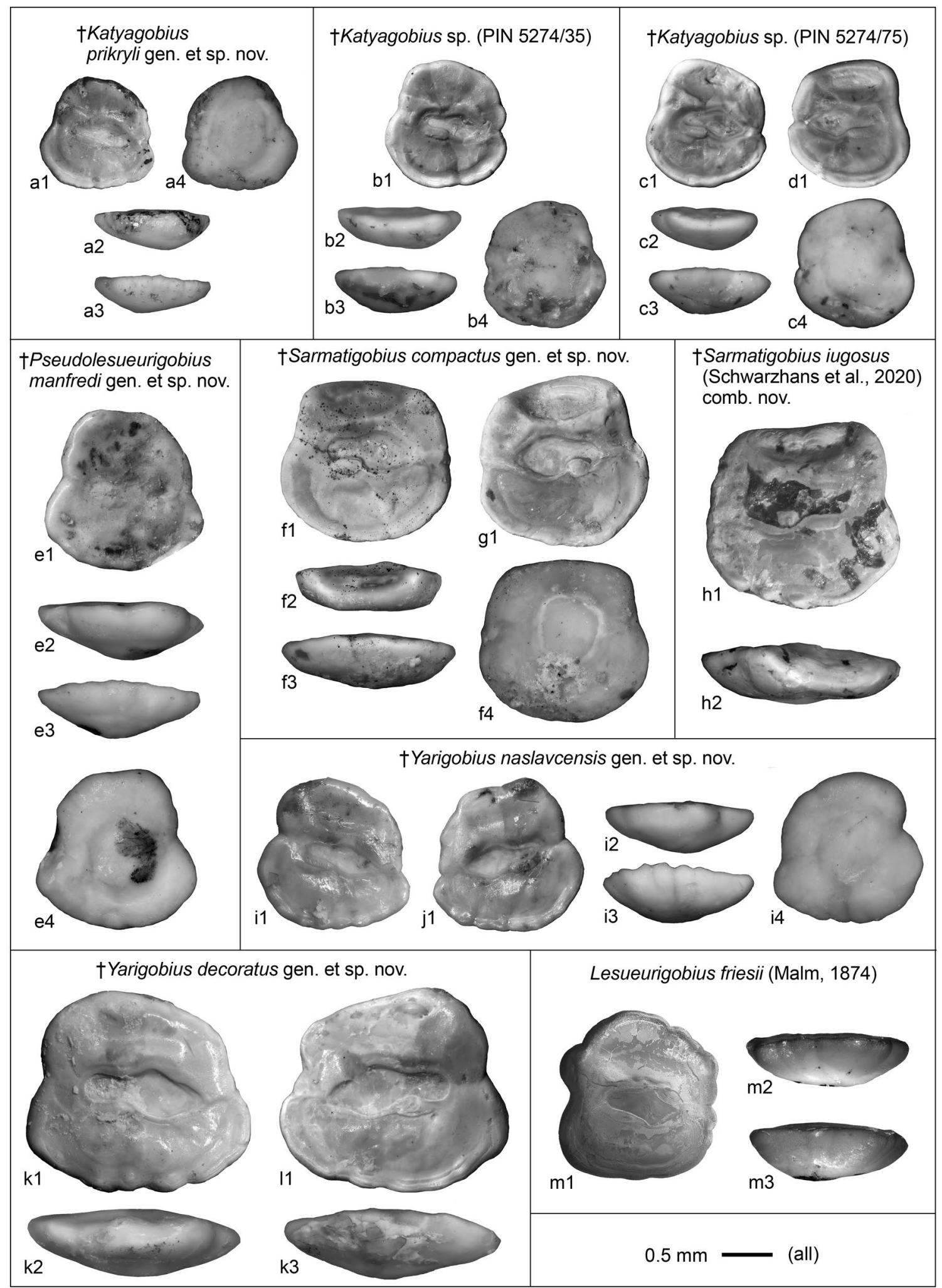

Jaws-The lower jaw is relatively long $(10.6 \% \mathrm{SL})$; the mandibular joint is situated opposite to the middle of the orbit. The dentary is narrow anteriorly and becomes deeper posteriorly; it has a broad coronoid process. A slightly displaced long anguloarticular is also visible. Both the dentary and the premaxilla bear curved and straight, relatively long, 
4Fig. 9 Saccular otoliths (sagittae) of the studied goby species from Karpov Yar, near Naslavcea, northern Moldova (a-l) and sagitta of a relatively small specimen $(35.6 \mathrm{~mm} \mathrm{SL})$ of the extant species Lesueurigobius friesii (Malm, 1874) from Galicia, Spain (m). Sagittae are depicted in inner (=medial) view (label ' 1 '), in dorsal view with outer (=lateral) face down (label ' 2 '), in ventral view with outer face down (label '3') and in outer view (label '4'). a left sagitta, holotype, PIN 5274/21. b left sagitta, PIN 5274/35. c, d left (c) and right sagitta, PIN 5274/75. e left sagitta, paratype, PIN 1306/81. f, g left (f) and right sagitta, holotype, PIN 5274/36. h right sagitta, PIN 5274/38. i, j left (j) and right sagitta, holotype, PIN 1306/71. k, I left (k) and right sagitta, holotype, PIN 5274/76. m, left sagitta, NMP6V 146226 (35.6 mm SL)

slender and pointed teeth of different sizes. The upper jaw bones are badly damaged; the preserved parts of the premaxilla bear a relatively long and slender ascending process and a wide, rounded articular process; the maxilla is not preserved.

Suspensorium, opercular apparatus and hyoid arch-The suspensorium and opercular bones are poorly preserved. Five branchiostegal rays are recognizable in more or less anatomical connection with the hyoid bar (Fig. 6a); the first ray is thin, the last one expanded; the shape of the hyoid bar is not clear.

Branchial arches-Most of the bones of the branchial skeleton are not identifiable. The well preserved and large lower (=ceratobranchial 5, see Kindermann et al. 2007) and upper pharyngeal jaws (= pharyngobranchials 2-4, see Kindermann et al. 2007) bear teeth of different sizes and shapes; most teeth are long, slender and either straight or slightly curved; some teeth are conical, more robust and shorter.

Vertebral column-There are 28 vertebrae, of which 10 are abdominal. The length of the abdominal part of the vertebral column is $52.9 \%$ of the length of the caudal part. The vertebral centra are constricted in the middle, with the centrum length being longer than the centrum height (holds for both abdominal and caudal centra). Only few parapophyses are recognizable. The first caudal vertebra bears a haemal spine that is almost as long as the second haemal spine (Fig. 5a2). Ribs are not easily recognizable (mostly covered by pectoral fin), the last two pairs are relatively short; tiny epineurals are also present. The supraneurals are absent.

Pectoral girdle and fins-The posttemporal is well preserved; its processes are long and slender, the upper process is slightly longer than the lower. The cleithrum is massive, long and only slightly curved. The pectoral radials are broad, but their precise shape is not discernible. The pectoral fin is relatively long (Fig. 5a1); it contains at least 10 (perhaps 12) thin rays.
Pelvic girdle and fins-The length of the pelvic fins is $16.1 \%$ $\mathrm{SL}$; each fin contains five soft rays and a robust, relatively long spine $(6.5 \%$ SL, $66 \%$ of adjacent ray), which is longer than the anal-fin spine. The pelvic-fin rays terminate distant from the origin of the anal fin (Fig. 5a2).

Dorsal fins - The D1 consists of six relatively robust spines (Fig. 7a); spines I-V taper posteriorly into short filaments; spine II longest (12.5\% SL); spine I slightly shorter $(86.6 \%$ of spine II); spines III and IV long (93.8 and $91.5 \%$ of spine II); spines V and VI decreasing in length (71.4\% and $45.9 \%$ of spine II, respectively); distance between spines $\mathrm{V}$ and VI relatively large (twice the distance between spines IV and V). The pterygiophore formula cannot be unambiguously defined, but is most probably 3-22110. The D2 inserts opposite to the origin of the first caudal vertebra (Fig. 5a2); it has a thin, curved, long spine ( $8.4 \% \mathrm{SL})$, narrowing to a filament distally; the number of segmented and branched D2 rays is 15 ; whether they reach the procurrent caudal-fin rays is not clear, because of the poor preservation in this region.

Anal fin-The anal fin inserts opposite to the junction between the second and third caudal vertebrae (roughly two vertebrae behind the origin of D2; Fig. 5a). It comprises a moderately long ( $4.8 \% \mathrm{SL})$, straight, thin spine and 14 segmented and branched rays; it is not clear whether their distal ends reach the caudal fin origin, owing to the poor preservation of the holotype in this region. Several anal-fin pterygiophores are visible; they are unusually short (but it is possible that only their distal parts are preserved); two pterygiophores insert before the haemal spine of the first caudal vertebra (Fig. 5a2).

Caudal endoskeleton and fin-The well-preserved caudal fin of the counterpart is lanceolate in shape (Fig. 5a1). The caudal fin is composed of 17 segmented principal rays, of which the outermost are not branched; 9 rays are found in the upper lobe. The proximal portion of the principal rays is covered by one to two vertical rows of ctenoid scales (Fig. 8a). Four and five procurrent rays are present dorsally and ventrally, respectively. The bones of the caudal endoskeleton are concealed by the dense scale cover.

Otoliths-For measurements of the sagitta and lapillus, see Table 1, for the described characters, see Figs. 9a, 10a.

Sagitta: Inner (= medial) face of sagitta flat; outer (= lateral) face convex, with large central hump covering about 2/3 of outer face; general sagitta shape slightly trapezoid, rounded; dorsal margin rounded, highest posteriorly, slightly indented in the middle; posterior margin slightly concave in the middle, ventral portion with protruding bulge; ventral margin faintly curved, with slight undulations; weak, 


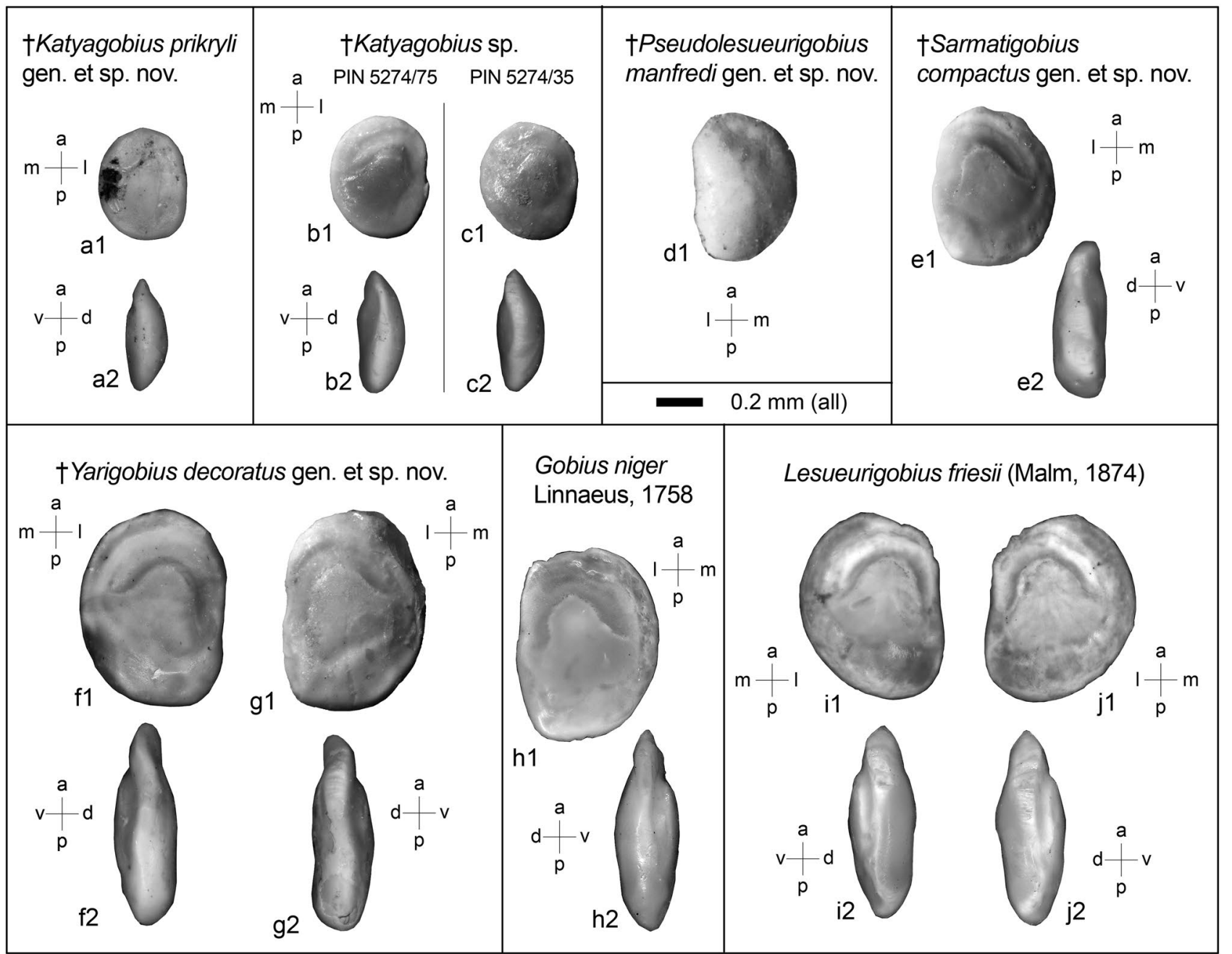

Fig. 10 Utricular otoliths (lapilli) of the new goby genera and species from Karpov Yar, near Naslavcea, northern Moldova $(\mathbf{a}-\mathbf{g})$ and of two extant gobiid species $(\mathbf{h}-\mathbf{j})$. Lapilli are depicted in ventral view (label ' 1 ') and in lateral view (label ' 2 '), anterior margin is at top. a left lapillus, PIN 5274/21. b, c left lapilli, d right lapillus, PIN 1306/81 (lateral view cannot be provided as lapillus disaggregated after

rounded preventral protuberance; anterior margin slightly undulated, with small incision above preventral protuberance, otherwise straight; ventral line relatively broad, ending with some distance from the ostium tip and cauda end; dorsal depression shallow; sulcus of 'shoe-sole' shape and moderately inclined $\left(\alpha=9.6-15.7^{\circ}\right)$; ostium elongate, with shallow upper and lower lobes; cauda narrow and terminally rounded; crista superior weak; crista inferior well developed along cauda and posterior part of ostium.

Lapillus: In ventral view, the lapillus is rectangular-to-ovate and exhibits a relatively long, horse-shoe-shaped cranial suture and well-defined sulculus; a linea basalis is not recognizable, possibly due to the small size of the lapillus; in extraction from the fossil specimen). e right lapillus, PIN 5274/36. f, $\mathbf{g}$ left (f) and right (g) lapillus, PIN 5274/76. h, right lapillus of specimen NMP6V 146077 (59.3 mm SL). i, j left (i) and right (j) lapillus of specimen NMP6V 146223 (45.2 mm SL). a = anterior margin, $d$ $=$ dorsal side, $1=$ lateral margin, $\mathrm{m}=$ medial margin, $\mathrm{p}=$ posterior margin, $\mathrm{v}=$ ventral side

lateral view it has a straight to weakly convex ventral outline, a symmetrically convex dorsal side, and a slightly tapering anterior tip. The lapillus is relatively thick.

Scales-All scales are ctenoid. The flank scales are ovate, relatively large and display relatively thick posterior margins (Fig. 11a); ctenii are short; radii appear to be absent (or may have been thin and were not preserved). Scale number in longitudinal row is about 32 . The predorsal scales are absent; the belly scales are similar to the flank scales, but slightly smaller. Two transverse rows of scales overlie the base of the caudal-fin rays (Fig. 8a). 


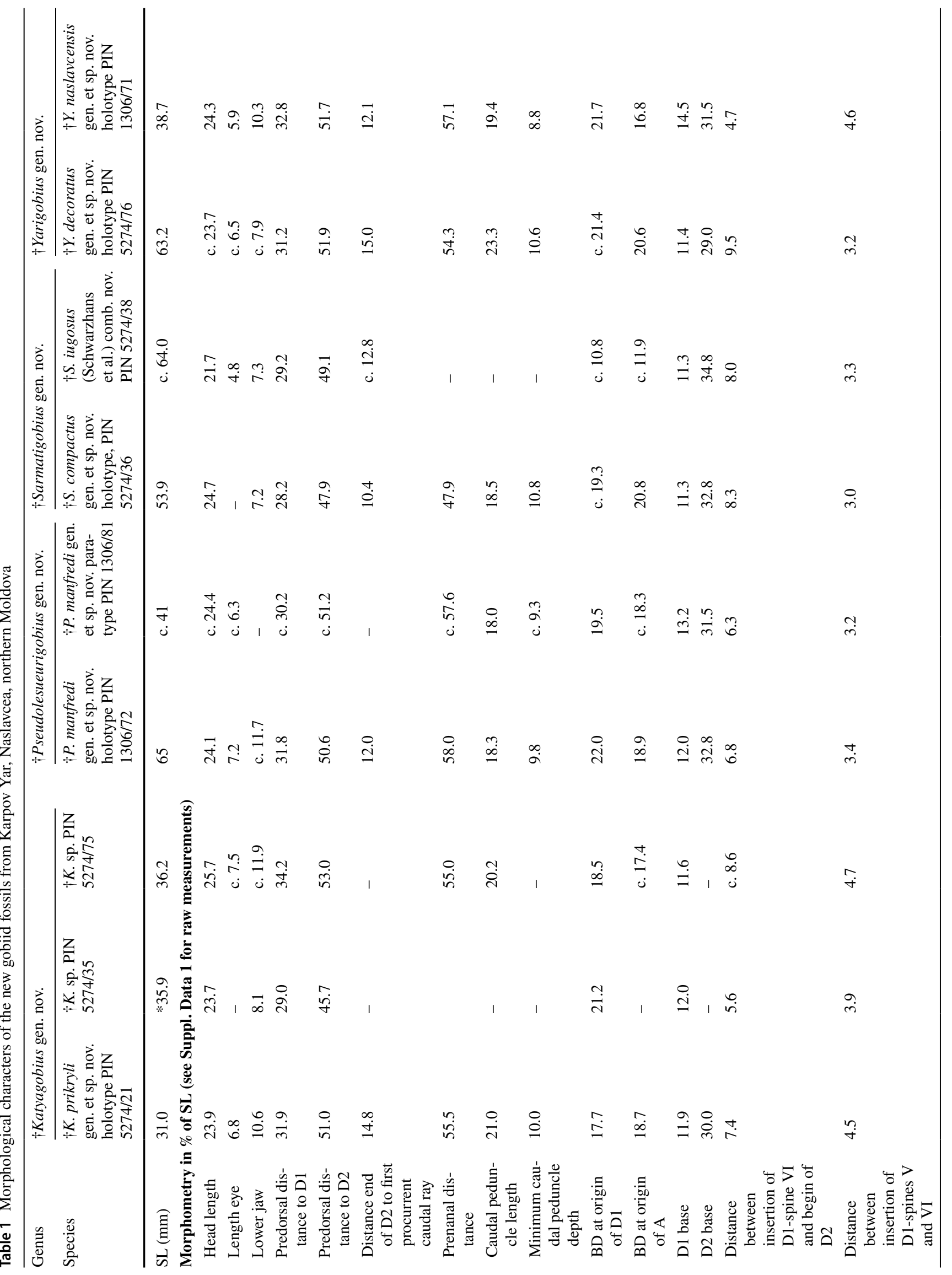




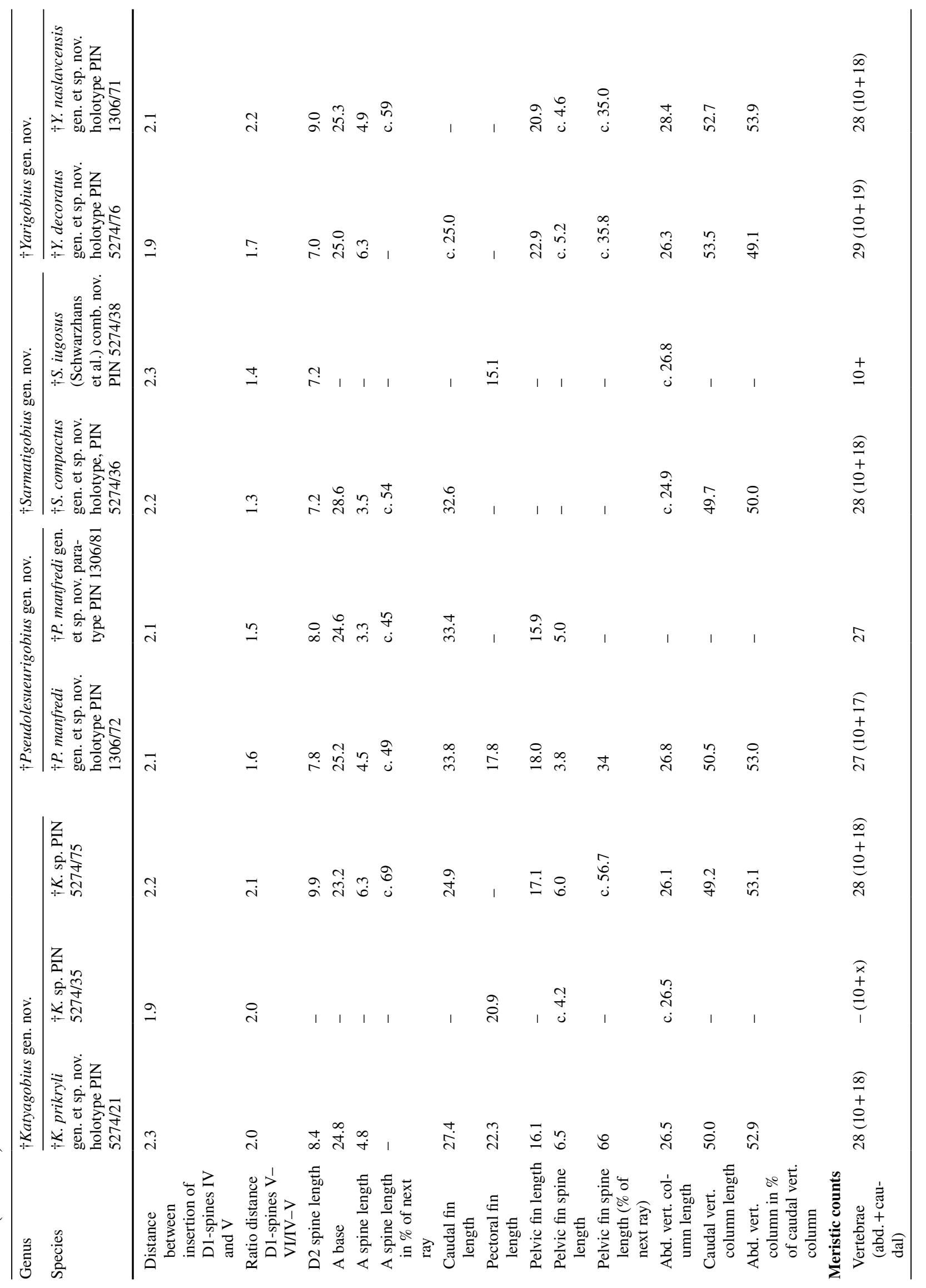




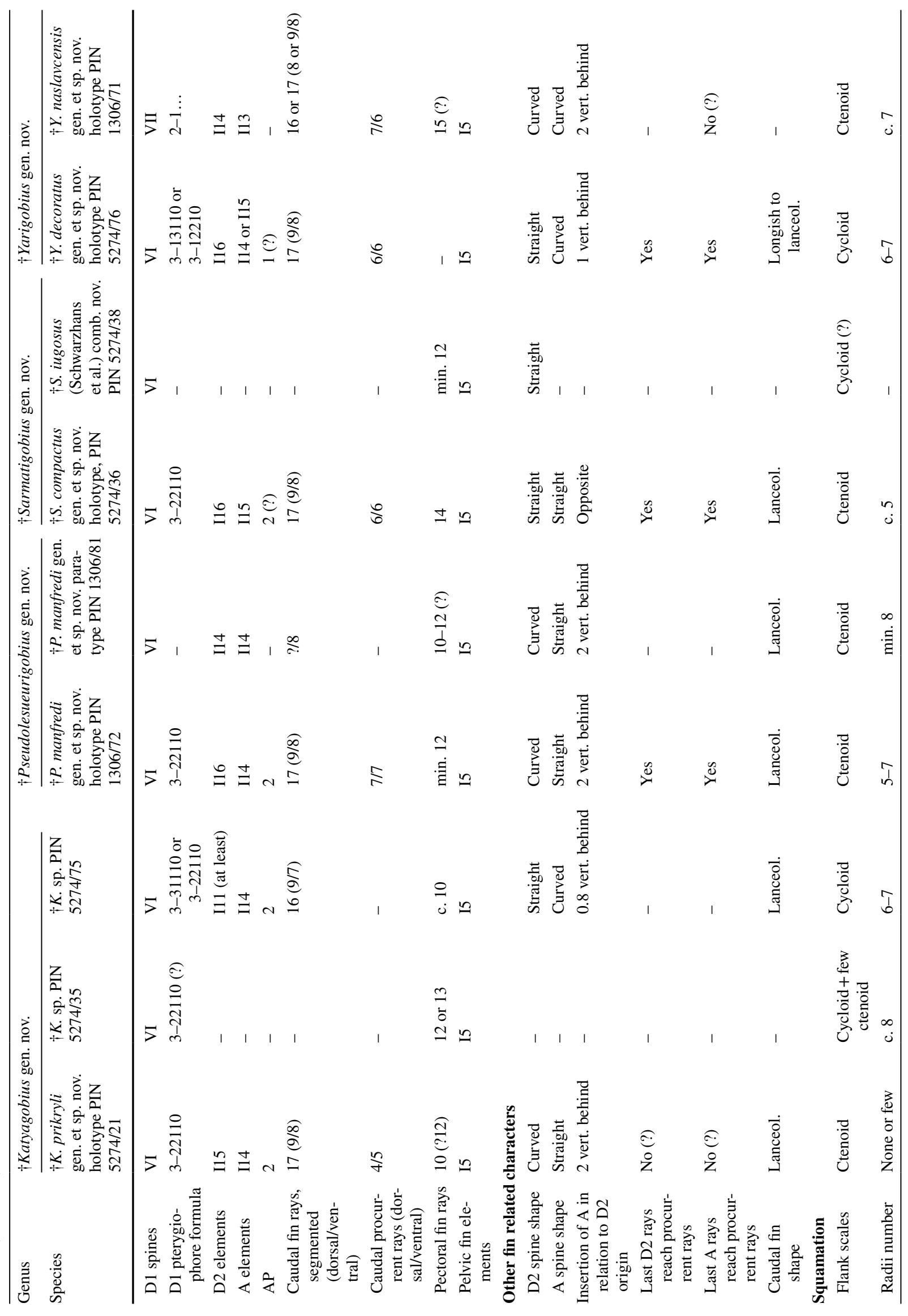




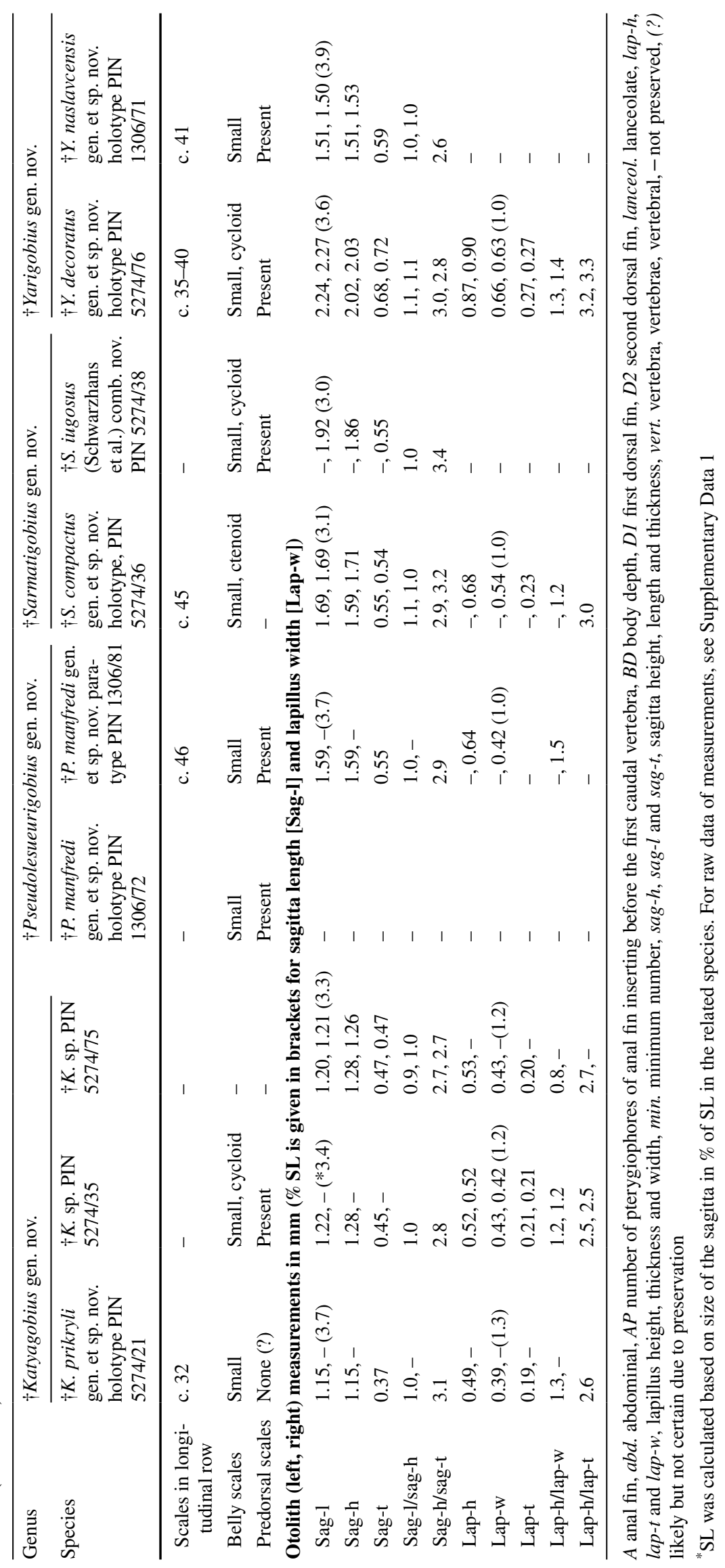


$\dagger$ Katyagobius sp.

Figures 6b, 7b, 9b-d, 10b, c; Table 1; Supplementary Data 3.

Material. Two incomplete specimens. PIN 5274/35a, b; estimated SL based on the sagitta size is $35.9 \mathrm{~mm}$; part and counterpart exhibiting the head and abdominal portion of the body in lateral view; part with left sagitta and both lapilli preserved in situ. Specimen PIN 5274/75a, b; SL 36.2 mm; part and counterpart in lateral view; part with well preserved head with both sagittae and left lapillus preserved in situ, abdominal portion of the body also relatively well preserved but caudal portion incomplete; counterpart almost complete, but poorly preserved.

Locality and age. Karpov Yar, Naslavcea, northern Moldova; lower Sarmatian.

Remarks. For body proportions and meristic counts of the two specimens, see Table 1. They have been assigned to $\dagger$ Katyagobius gen. nov. because they share with the type species, $\dagger K$. prikryli gen. et sp. nov., the configuration of the last three D1-spines, with the distance between spines $\mathrm{V}$ and VI being twice the distance as between spines IV and V. Furthermore, they share with the type species the presence of a relatively long and robust pelvic fin spine, and the shape, relative thickness and contour of the lapilli (Fig. 10b, c). The two specimens differ from $\dagger K$. prikryli gen. et sp. nov. because their flank scales are exclusively (PIN 5274/75) or mostly cycloid (PIN 5274/35) (vs. exclusively ctenoid in $\dagger K$. prikryli gen. et sp. nov.). Their sagittae display a more rounded ventral margin and a slightly thicker dorsal margin as seen in $\dagger K$. prikryli gen. et sp. nov., the latter characteristic is especially well visible in the dorsal views of the sagittae (Fig. 9b2, c2).

Differences between the two specimens include the length of the lower jaw (estimated 8.1\% SL in PIN 5274/35 vs. $11.9 \%$ SL in PIN 5274/75), the predorsal distance to D1 (estimated $29.0 \%$ SL in PIN 5274/35 vs. $34.2 \%$ SL in PIN 5274/75), the predorsal distance to D2 (estimated 45.7\% SL in PIN 5274/35 vs. 53.0\% SL in PIN 5274/75), the number of pectoral fin rays (12 or 13 in PIN $5274 / 35$ vs. c. 10 in PIN 5274/75) and the squamation (cycloid plus a few ctenoid scales in PIN 5274/35 vs. exclusively cycloid in PIN 5274/75). Also, the sagittae of the two specimens differ slightly from each other in the curvature of the dorsal margin (well rounded in PIN 5274/35 vs. flattened in PIN $5274 / 75$, see Fig. $9 b 1$ vs. c1, d1), in the curvature of the inner face (plan in PIN 5274/35 vs. slightly concave in PIN 5274/75, see Fig. 9b2 vs. c2) and also in the curvature of the outer face (moderately thickened in PIN 5274/35 vs. strongly thickened in PIN 5274/75). These differences could indicate the presence of two species, but, as each of the specimens is incomplete, we prefer to leave them in open nomenclature.

Genus $\uparrow$ Pseudolesueurigobius gen. nov.

Type species. $†$ Pseudolesueurigobius manfredi gen. et sp. nov. (Figs. 5b, 6d, e, 7c, 8b, 9e, 10d, 11b).

Other species. None.

Etymology. The generic name refers to the similarity of this fossil genus to the extant gobiid Lesueurigobius Whitley, 1950. Gender masculine.

LSID ZooBank. This new genus is registered under LSID urn:1sid:zoobank.org:act:78B80CDA-2630-45E6-8E12AF21FFAB9AF8.

Stratigraphic range. Lower Sarmatian.

Diagnosis. Medium-sized gobiid fish up to $65 \mathrm{~mm}$ SL. Head moderately large (24.1-24.4\% SL); body probably laterally compressed (being preserved in lateral view); pre-anal distance relatively long (57.6-58\% SL); anal fin inserted two vertebrae behind D2; anal-fin base moderately long (24.6$25.2 \%$ SL); caudal peduncle moderately long (18.0-18.3\% SL); caudal fin lanceolate and longer than head (33.4-33.8\% SL); length of abdominal part of vertebral column approx. $53 \%$ of length of caudal part of vertebral column. Total number of vertebrae $27(10+17)$; D1 with six slender, distally filamentous spines; distance between the D1-spines V and VI relatively short (3.2-3.4\% SL); pterygiophore formula 3-22110; D2 with relatively long spine (7.8-8.0\% SL) tapering to a distal filament and 14-16 segmented rays; anal fin with relatively short spine (3.3-4.5\% SL) and 14 segmented rays. Pectoral fin with about 12 rays. Pelvic fin with moderately long spine (3.8-5.0\% SL, 34\% of adjacent ray) and five rays; end of pelvic rays distant from anal-fin origin. Caudal fin with 17 segmented rays, 9 rays in the upper lobe. Relatively dense cover of ctenoid scales on body.

Otoliths-Sagitta trapezoid-to-rounded in shape, with the ventral portion being distinctively wider than the dorsal part; sulcus 'shoe-sole'-shaped, moderately inclined $\left(\alpha=9.8^{\circ}\right)$, with well-developed crista superior and crista inferior. Lapillus more or less ovate and tapering posteriorly; lateral margin relatively straight; medial margin strongly convex.

Differential diagnosis. With respect to the presence of a lanceolate caudal fin, high number of rays in the D2 and anal fin, and general proportions of head and body, Lesueurigobius Whitley, 1950 and the three other new fossil genera described in this study, i.e., $\dagger$ Katyagobius gen. nov., 
†Katyagobius prikryli gen. et sp. nov.
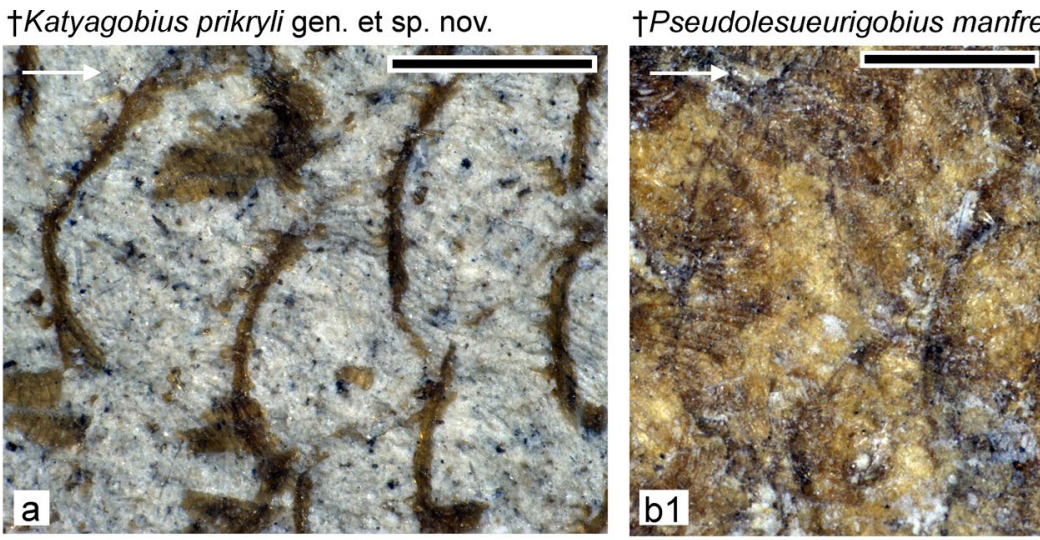

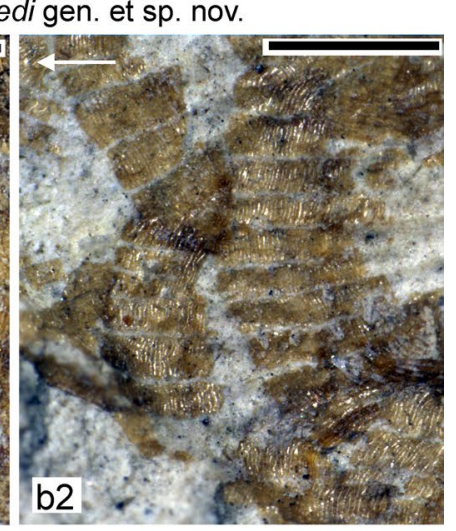

†Sarmatigobius compactus gen. et sp. nov.

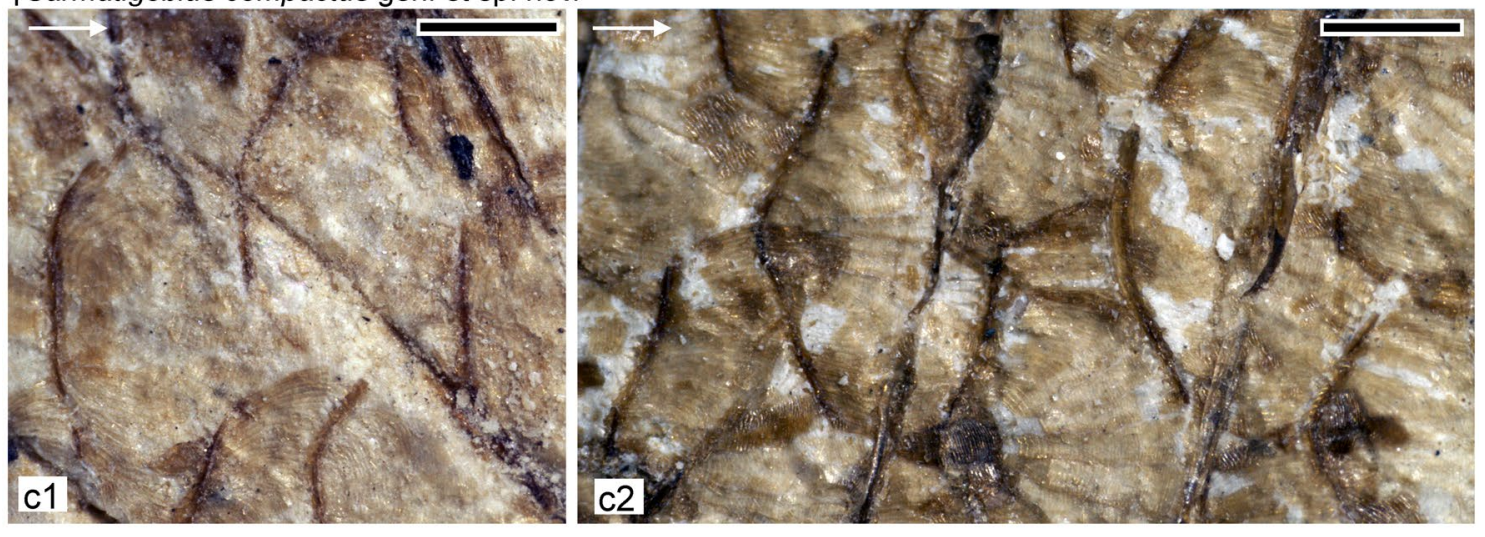

†Yarigobius decoratus gen. et sp. nov.
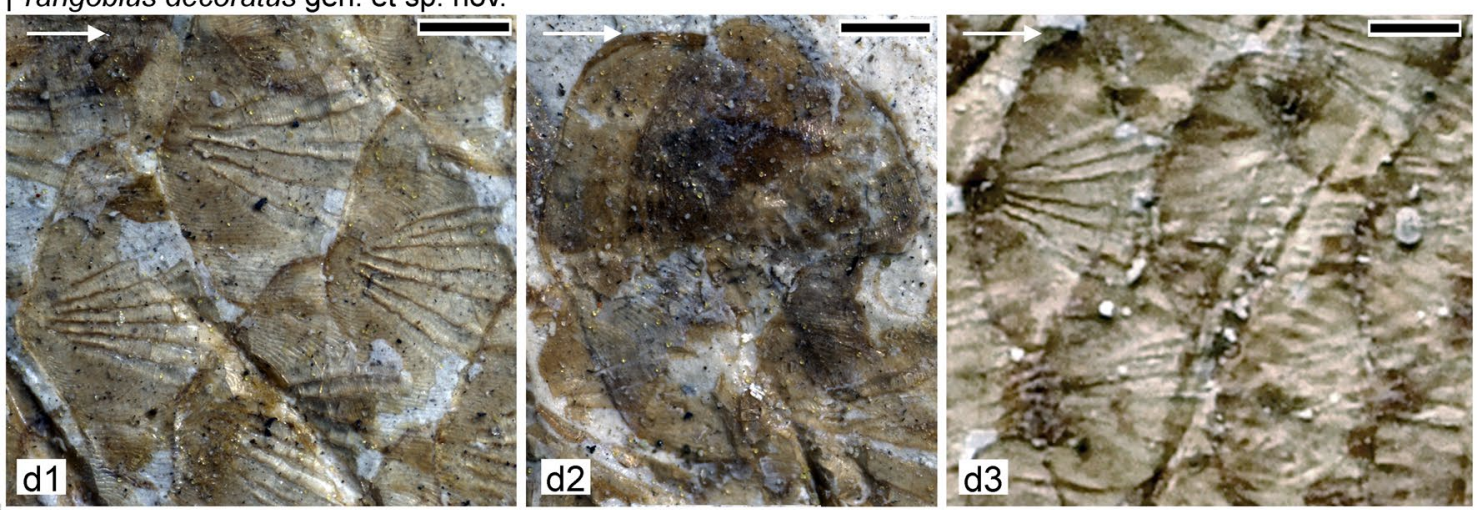

†Yarigobius naslavcensis gen. et sp. nov.
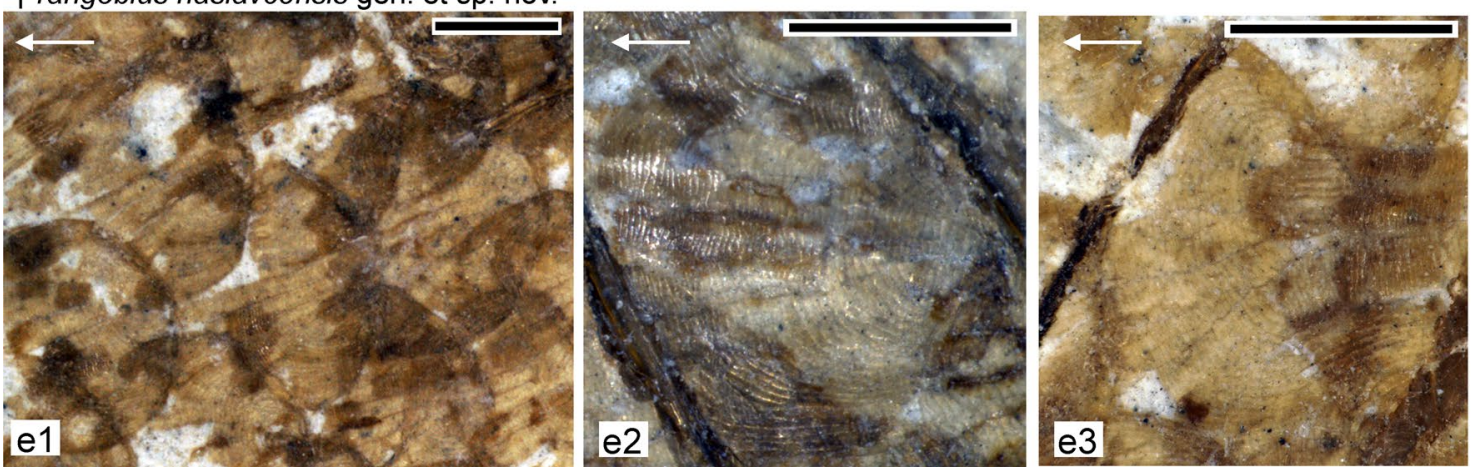
४Fig. 11 Squamation of the studied new goby species from Karpov Yar, near Naslavcea, Moldova. a holotype, PIN 5274/21a, above anal fin, lateral view. b paratype, PIN 1306/81; b1 below second dorsal fin, medial view (part); b2 third scale row below spine of second dorsal fin, lateral view (counterpart). c holotype, PIN 5274/36, medial view; c1 beneath first dorsal fin; c2 above anterior third of anal fin. d holotype, PIN 5274/76, (medial view); d1 beneath end of second dorsal fin (see box in Fig. 5f); d2 large 'decorative' scale on caudal peduncle (see box in Fig. 5f); d3 just before anal fin insertion. e holotype, PIN 1306/71, medial view; e1 beneath anterior third of second dorsal fin; e2 above anal fin; e3 below second dorsal fin. White arrows point anteriorly. All scale bars $0.5 \mathrm{~mm}$

$†$ Sarmatigobius gen. nov., and †Yarigobius gen. nov. are phenotypically similar to $†$ Pseudolesueurigobius gen. nov. (see Table 1 for data on the fossils and Appendix Table for data on Lesueurigobius). The total number of vertebrae (27 vs. 28) differentiates $\uparrow P$ seudolesueurigobius gen. nov. from the three other new fossil genera, but not from Lesueurigobius. The main diagnostic character of $\dagger$ Pseudolesueurigobius gen. nov. is the sagitta shape (trapezoid, wide ventrally and comparatively narrow dorsally; see Fig. 9e1), which is very different from the otoliths of the aforementioned other extinct genera (Fig. 9a1-d1, f1-k1) and from otoliths of Lesueurigobius (Fig. 12). Also the lapillus shape is distinctive when compared to the other extinct genera (Fig. 10d1 vs. Fig. 10a1-c1, e1-g1), whereas it bears some similarity to the lapillus of Lesueurigobius (Fig. 10i1, j1) in its posteriorly tapered shape and the strong curvature of the medial margin.

Apart from the aforementioned characters, $†$ Pseudolesueurigobius gen. nov. can be distinguished from $\dagger$ Katyagobius gen. nov. by the shorter distance between D1-spines V and VI (3.2-3.4\% SL vs. 3.9-4.7\% SL); the slightly shorter caudal peduncle (18.0-18.5\% SL vs. 20.2-21.0\% SL), and the relatively longer caudal fin (32.6-33.8\% SL vs. 24.9$27.4 \%$ SL); from $†$ Sarmatigobius gen. nov. by its relatively longer preanal distance (57.6-58\% SL vs. 47.9\% SL), a slightly shorter anal fin base (24.6-25.2\% SL vs. $28.6 \%$ $\mathrm{SL}$ ), and the more posterior insertion of the anal fin (two vertebrae behind D2 vs. opposite); and from †Yarigobius gen. nov. by the relatively longer caudal fin (33.4-33.8\% SL vs. $25.0 \% \mathrm{SL})$, and a D1 pterygiophore formula starting with $3-2 \ldots$ (vs. 3-1...).

Notably, none of the morphometric or meristic characters of the skeleton differed between Pseudolesueurigobius gen. nov. and Lesueurigobius. The only differences refer to the scale size and the sagitta shape; Lesueurigobius has relatively larger scales (number of scales in the longitudinal row is 26-28 vs. about 46 in $†$ Pseudolesueurigobius) and the sagitta shape in Lesueurigobius is almost rectangular (Figs. 9m1, 12) vs. trapezoid-to-rounded in $†$ Pseudolesueurigobius (Fig. 9e1). $\uparrow$ Pseudolesueurigobius manfredi gen. et sp. nov. Figures 5b, 6d-e, 7c, 8b, 9e, 10d, 11b; Table 1

Type material. Holotype, PIN 1306/72a, b, 65 mm SL; part and counterpart, each incomplete, but well preserved (part: posterior body and caudal fin in lateral view; counterpart: head in dorsolateral view, anterior half of body in lateral view); otoliths not preserved. Paratype, PIN 1306/81a, b, c. $41 \mathrm{~mm} \mathrm{SL}$; part and counterpart, each incomplete and partially damaged, in lateral view; part with left sagitta and right lapillus preserved in situ.

Type locality and age. Karpov Yar, Naslavcea, northern Moldova; lower Sarmatian.

Etymology. The species epithet is in honour of the husband of BR, Manfred Reichenbacher, for his patient and continuous support of our work on the fossil gobies from Naslavcea.

LSID ZooBank. This new species is registered under LSID urn:1sid:zoobank.org:act:1B5C41B5-5D55-43D0-A9BFC4E88D66C994.

Diagnosis. SL up to $65 \mathrm{~mm}$. Head moderately large (24.1$24.4 \%$ SL); preanal distance relatively long (57.6-58.0\% $\mathrm{SL})$; caudal peduncle moderately long (18.0-18.3\% SL); caudal fin lanceolate and longer than head (33.4-33.8\% SL); relatively short first spine of D1 (73\% of length of second spine); spine of D2 relatively long (7.8-8.0\% SL) and tapering to a filament; anal-fin spine and pelvic-fin spine of approximately the same size (3.3-5.0\% SL); pelvic-fin spine length is about $34 \%$ of adjacent pelvic ray; relatively dense cover of ctenoid flank scales with not thickened posterior margins; about 46 scales in the longitudinal row. Other characters as described in the generic diagnosis.

General description. Medium-sized gobiid fish up to $65 \mathrm{~mm}$ SL (Fig. 5b); body cone-shaped and probably laterally compressed (being preserved in lateral view); head of moderate size (24.1-24.4\% SL); anal fin inserting two vertebrae behind D2; caudal peduncle moderately long (18.0-18.3\% $\mathrm{SL})$; caudal fin lanceolate and long (33.2-33.8\% SL). For further body proportions and meristic counts, see Table 1.

Neurocranium - The neurocranium is preserved in lateral view; it is relatively deep, but most of its bones are not well preserved. The eyes are relatively large (6.3-7.2\% SL). The frontal bones are long and oriented obliquely to the body axis over the orbit, narrow between the orbits and broad posteriorly. The parasphenoid is a straight, thin rod with a broad posterior portion; the vomer is recognizable, but its shape cannot be traced. The ethmoid region is short. It is not clear whether scales are present on the head. 

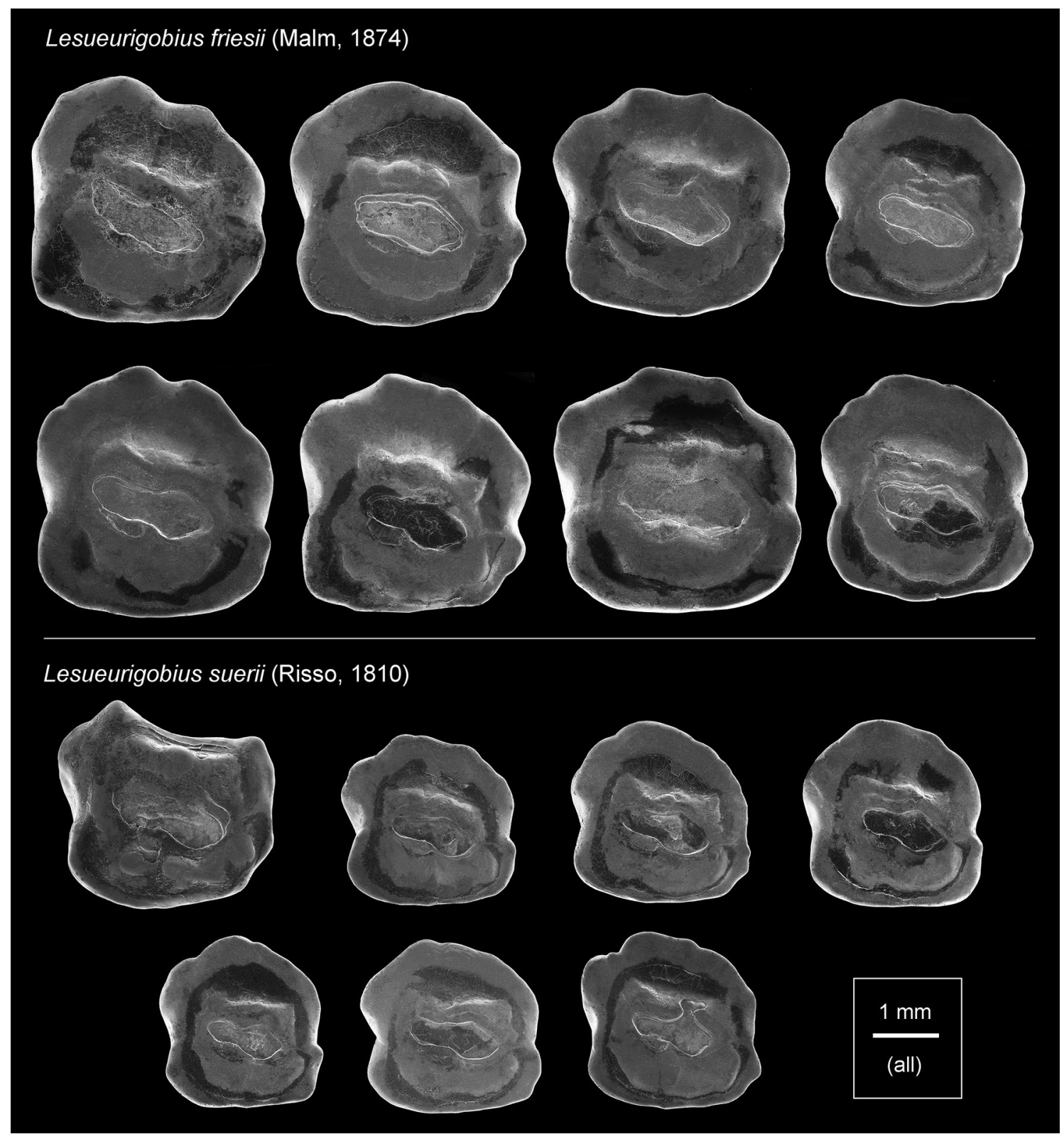

Fig. 12 Sagittae (medial view) of two species of Lesueurigobius (collection IRSNB)

Jaws - The lower jaw is of moderate length (11.7\% SL in the holotype, not measurable in the paratype); the lower jaw articulation is situated opposite to the middle of the orbit. The upper jaw bones are damaged, the maxilla is not recognizable. The premaxilla displays a fragment of the articular process and the beginning of the postmaxillary process, the ascending process is not preserved. The oral jaw dentition is only poorly preserved, but relatively robust, sharp conical teeth can be recognized.
Suspensorium, opercular apparatus and hyoid arch-Most of these bones are poorly preserved. A roughly triangular opercle and a crescent-shaped subopercle are detectable, while only fragments of the preopercle, branchiostegal rays and hyoid bars are present.

Branchial arches-Most of the bones of the branchial skeleton are not identifiable. Pharyngeal jaws are massive; the pharyngeal dentition is represented by relatively big, thick, and blunt teeth as well as by sharp, slender, conical teeth. 
Vertebral column-There are 27 vertebrae, of which 10 are abdominal. The vertebral centra are constricted in the middle, with the centrum length (in both abdominal and caudal centra) being longer than the centrum height. Few parapophyses are recognizable. The length of the abdominal part of the vertebral column is $53 \%$ of the length of the caudal portion. The first caudal vertebra bears a haemal spine that is slightly approached towards the following haemal spine, and seems to be slightly shorter than the following haemal spine (Fig. 5b). At least seven pairs of slender ribs are present; the first five pairs are moderately long, and the last two relatively short; tiny epineurals are also present. The supraneurals are absent.

Pectoral girdle and fins-The posttemporal is incompletely preserved; its processes are long and slender. The cleithrum is robust, long and only slightly curved (Fig. 5b). The pectoral radials are broad, but their shapes are not recognizable. The pectoral fin length is $17.8 \% \mathrm{SL}$; it contains at least 12 thin rays.

Pelvic girdle and fins-The basipterygium is somewhat triangular. The pelvic fins seem to be close to each other (Fig. 6d); their length is $15.9-18.0 \%$ SL. Each pelvic fin contains a moderately long spine $(3.8-5.0 \% \mathrm{SL})$ and five rays that are highly segmented and branched distally; proximally they seem to be unsegmented. The rays terminate distant from the origin of the anal fin.

Dorsal fins - The D1 has six slender spines, all of which taper into short filaments (Fig. 7c); length of first D1-spine approx. 73\% of spine II; spines II to IV of similar lengths, spine IV is the longest (13.7\% SL); spines V and VI decreasing in length (76\% and $53 \%$ of spine II); the distance between spines V and VI is 1.5-1.6 times greater than that between spines IV and V; the pterygiophore formula is 3-22110. D2 inserts opposite to the last abdominal and first caudal vertebrae; it has a slightly bent, distally filamentous spine and 14 (paratype) or 16 (holotype) segmented and branched rays; the rays become progressively longer posteriorly and terminate above the last dorsal procurrent ray of the caudal fin (Fig. 8b).

Anal fin-The anal fin inserts below the third caudal vertebra, i.e., two vertebrae behind the origin of D2 (Fig. 5b). It comprises one moderately long, straight and slender spine (3.3-4.5\% SL) and 14 rays; most of these rays are of similar length, and those farthest posterior terminate opposite to the first two caudal procurrent rays (Fig. 8b). The spine is supernumerary on the first pterygiophore. There are two anal-fin pterygiophores that insert before the haemal spine of the first caudal vertebra (Fig. 5b).
Caudal endoskeleton and fin-The caudal fin is wide, relatively long (33.4-33.8\% SL) and lanceolate in shape (Fig. 5b). It is composed of 17 segmented principal rays, of which the outermost are not branched; 9 principal rays are present in the upper lobe. Six procurrent rays occur both dorsally and ventrally (visible in the holotype); the last two ventral procurrent rays display their forked bases. The caudal skeleton has two large hypural plates $(\mathrm{HY} 1+2$ and HY3 +4 ), of which the upper is fused with the terminal centrum; hypural 5 is slender and short (Fig. 6e). There are imprints of a long, relatively broad parhypural that almost reaches the terminal centrum, and of a long, distally widened epural (Fig. 6e). The second preural vertebra (PU2) has a shortened neural spine, and a long, broad haemal spine, which supports the last ventral procurrent ray and the first two principal rays (Fig. 6e).

Otoliths - For measurements of the sagitta and lapillus, see Table 1, for the described characters, see Figs. 9e, 10d.

Sagitta: Inner (=medial) face flat; outer (= lateral) face convex, with centrally located, clearly delimited hump which takes up about one-third of the outer face; sagitta shape is trapezoid-to-rounded, with the ventral portion being distinctly wider than the dorsal part; dorsal margin relatively short, rounded, with slight concavity in the middle; posterior margin with distinct concavity in the midway, lower half with prominent posteroventral protrusion; ventral margin strongly symmetrically curved; preventral portion less protruding than posteroventral; anterior margin indented in the lower one-third and rounded above; ventral line shallow, anteriorly terminating opposite to the ostium tip, posteriorly ending at the tip of the posteroventral protrusion and distant from the end of the cauda; dorsal depression shallow; sulcus of 'shoe-sole' shape, moderately inclined $\left(\alpha=9.8^{\circ}\right)$; well-developed crista superior and crista inferior; the crista inferior is slightly thickened along the anterior cauda; ostium with triangular dorsal ostial lobe near the transition to the cauda; cauda oblong and terminally rounded.

Lapillus: Shape more or less ovate, tapering posteriorly; lateral margin relatively straight; medial margin strongly convex; cranial suture moderately well defined, sulculus curved and relatively short. Further details cannot be reported as the lapillus unfortunately disintegrated during extraction from the specimen.

Scales - The flank scales are ctenoid, round and ovate and relatively thin, their ctenii are short (Fig. 11b1); 5-8 relatively weak radii are present (Fig. 11b2). Scale number in longitudinal row is about 46 (based on the paratype). The belly and predorsal scales are smaller than the flank scales, 
whether or not they are also ctenoid cannot be decided. Thin scales also cover the bases of the caudal-fin rays (Fig. 8b).

Genus $\uparrow$ Sarmatigobius gen. nov.

Type species. $†$ Sarmatigobius compactus gen. et sp. nov. (Figs. 5c, 7e, 8c, 9f-g, 10e, 11c).

Other species. †Sarmatigobius iugosus (Schwarzhans, Brzobohatý and Radwańska, 2020) comb. nov. (Figs. 5d, $6 \mathrm{c}, 7 \mathrm{~d}, 9 \mathrm{~h}$ ) from the upper Badenian to lower Sarmatian of the Central Paratethys and Moldova.

Etymology. The name refers to the distribution of this taxon (Sarmatian) and its general similarity to members of the Gobiidae. Gender masculine.

LSID ZooBank. This new genus is registered under urn:lsid:zoobank.org:act:076CD640-BCFE-410B-835F59FBD934D5EE.

Stratigraphic range. Upper Badenian to Lower Sarmatian.

Diagnosis. Medium-sized fish of 54-64 mm SL; head moderately large (21.7-24.7\% SL); body probably laterally compressed (being preserved in lateral view); D1 and D2 widely separated; anal fin inserted opposite to D2; relatively short preanal distance $(47.9 \% \mathrm{SL})$; relatively long anal-fin base ( $28.6 \% \mathrm{SL})$; caudal peduncle moderately long $(18.5 \% \mathrm{SL})$; caudal fin lanceolate and longer than head (approx. 32.6\% $\mathrm{SL}$ ); length of abdominal part of vertebral column approx. $50 \%$ of length of caudal part of vertebral column. Number of vertebrae $28(10+18)$; D1 with six spines, first five spines with short distal filaments; D2 with straight, relatively long spine (7.2\% SL) and 16 segmented rays; anal fin with thin, straight, relatively short spine (3.5\% SL) and 15 segmented rays. Pectoral fin with up to 14 rays; pelvic fins with spine and five rays; ends of pelvic rays distant from anal-fin origin. Caudal fin with 17 segmented rays, 9 rays in the upper lobe. Relatively dense cover of ctenoid (in type species) or probably cycloid scales (in $\dagger S$. iugosus) on body.

Otoliths-Sagitta of squarish-to-ventrally rounded shape, with very deep dorsal depression that extends to the dorsal margin; sulcus 'shoe-sole'-shaped and slightly inclined $\left(\alpha=5.0-7.6^{\circ}\right)$, with prominent subcaudal iugum. Lapillus of ovate shape in ventral view; in lateral view wedge-shaped, with the thickest part located posteriorly.

Differential diagnosis. With respect to the presence of a longish caudal fin, high number of rays in the D2 and anal fin, and general proportions of head and body, Lesueurigobius Whitley, 1950 and the three other new fossil genera described in this study, i.e., $†$ Katyagobius gen. nov., $\dagger P$ seudolesueurigobius gen. nov., and †Yarigobius gen. nov. are phenotypically similar to $†$ Sarmatigobius gen. nov. (see Table 1 for data on the fossils and Appendix Table for data on Lesueurigobius). Three skeleton-based characters clearly differentiate $\dagger$ Sarmatigobius gen. nov. from these, namely its relatively shorter preanal distance (47.9\% SL vs. $54.3-58.0 \%$ SL), a longer anal-fin base (28.6\% SL vs. $23.2-25.3 \%$ SL), and the insertion of the anal fin opposite to D2 (vs. 1.5-2 vertebrae behind). Moreover, $†$ Sarmatigobius gen. nov. has a very distinctive sagitta morphology (in terms of overall shape, dorsal depression, shallow sulcus inclination angle; see diagnosis), and also the wedge-shaped lateral view of the lapillus is unique (see diagnosis).

Remarks. The otoliths of a species originally named $\dagger$ Hesperichthys iugosus Schwarzhans, Brzobohatý and Radwańska, 2020 share with the otoliths of $†$ Sarmatigobius nov. gen. a squarish-to-rounded shape, a very deep dorsal depression and a weakly inclined sulcus. No skeleton has been reported for $\dagger H$. iugosus; it was defined on the basis of three otoliths from the upper Badenian to lower Sarmatian of the Central Paratethys (Schwarzhans et al. 2020b). Its assignment to the genus $\dagger$ Hesperichthys Schwarzhans, Ahnelt, Carnevale and Japundžić, 2017 was based on the similarity with otoliths of $\uparrow$ Hesperichthys reductus Schwarzhans, Ahnelt, Carnevale and Japundžić, 2017, of which the skeleton is also known. According to the original description of the skeleton of $\dagger$ Hesperichthys in Schwarzhans et al. (2017a), it is obvious that $\dagger$ Hesperichthys and $\dagger$ Sarmatigobius gen. nov. differ from one another in many characters and cannot represent the same genus. For instance, there are four interneural spaces between the D1 and D2 in $\dagger$ Hesperichthys (vs. one in †Sarmatigobius gen. nov.), the number of abdominal vertebrae is 11 (vs. 10), there are nine soft rays in the D2 (vs. 16), and ten soft rays are present in the anal fin (vs. 15). The otoliths found in situ in the holotype and paratype of $\dagger$ H. reductus clearly differ from those of $\dagger$ Sarmatigobius gen. nov. insofar as the sulcus shows no clear boundary/distinction between ostium and cauda (vs. clear separation), a dorsal depression is lacking (vs. strongly developed) and the outer face is strongly convex (vs. moderately convex) (Schwarzhans et al. 2017a: fig. 11f, g). The superficial similarity between the otoliths of $\dagger H$. reductus and $†$ Sarmatigobius gen. nov. is mainly attributable to the low inclination angle of the sulcus, which is common to both. Schwarzhans et al. (2017a) also assigned some isolated otoliths from the Sarmatian deposits to $\dagger$. reductus. Among them, one displays a clear separation of the ostium from the cauda and a deep dorsal depression that extends to the dorsal margin (see Schwarzhans et al. 2017a: fig. 11h); this single otolith is here tentatively assigned to $\dagger$ Sarmatigobius sp. 
$\dagger$ Sarmatigobius compactus gen. et sp. nov.

Figures 5c, 7e, 8c, 9f, g, 10e, 11c

Type material. Holotype; PIN 5274/36a, b, 53.9 mm SL. Preserved as part and counterpart, with both sagittae and right lapillus in situ; part almost completely preserved, counterpart comprises well preserved head and anteriormost portion of body.

Type locality and age. Karpov Yar, Naslavcea, northern Moldova; lower Sarmatian.

Etymology. The species name refers to the compact body shape of this species.

LSID ZooBank. This new species is registered under urn:1sid:zoobank.org:act:478D15FB-63B2-40E6-B563F062DA145D5B.

Diagnosis. Differentiated from the only other species currently known, $\dagger S$. iugosus (Schwarzhans et al. 2020a, b), by robust oral jaw teeth (vs. very slender), a slightly longer head (24.7\% SL vs. $21.7 \%$ SL), a greater body depth (19.3\% SL vs. $11.9 \%$ SL), a slightly shorter distance between the D1-spines V and VI (3.0\% SL vs. 3.3\% SL), and the presence of ctenoid scales (vs. probably cycloid). There may be further differences between the skeletons of the two species, which are currently not recognizable because the preservation of $\dagger S$. iugosus is only moderate. The differences between the sagittae of the two species include: almost flat or slightly rising dorsal margin in $\dagger S$. compactus gen. et sp. nov. (vs. slightly concave in $\dagger S$. iugosus); no prominent protuberance at the posterior end of the dorsal margin (vs. present); and presence of ovate, very thick subcaudal iugum (vs. longish and less thick).

General description. Medium-sized gobiid fish; SL $53.9 \mathrm{~mm}$ (Fig. 5c). Body preserved in lateral view (Fig. 5c2), head in dorsolateral view (Fig. 5c1). Body slightly cone-shaped; head of moderate size (24.7\% SL); D2 and anal fin inserting opposite to each other; relatively long caudal peduncle $(18.5 \% \mathrm{SL})$; caudal fin lanceolate and longer than head $(32.6 \% \mathrm{SL})$. For further body proportions and meristic counts, see Table 1.

Neurocranium-The neurocranium is preserved in dorsolateral view and seems to be moderately deep, but individual bones of the braincase are barely recognizable. The parasphenoid borders the lower margin of the orbit; it is straight, and relatively narrow, with a broad posterior portion. The vomer is rounded anteriorly. The ethmoid part of the neurocranium is relatively short. Head scales are not present (or not preserved).
Jaws - The mouth gape is moderately wide; the lower jaw articulation is situated slightly anterior to the middle of the orbit. The maxilla is slender and elongate, slightly broader posteriorly and somewhat bent in its anterior portion. The premaxilla has a very thin ascending process and a broad articular process; the posterior part of the premaxilla is poorly preserved. Premaxillary teeth seem to be strong and robust. The dentary is narrow and long; it bears relatively large and robust teeth. Further details of the jaws are not recognizable.

Suspensorium, opercular apparatus and hyoid arch-The suspensorium bones are poorly preserved. The quadrate is a roughly triangular bone with a deep and wide indentation in its posterodorsal portion and a strong, thick and pointed posterior process. Bones of the opercular region are too poorly preserved to be described. The hyoid bar (ceratohyal + epihyal) is relatively straight, the anterior portion of the ceratohyal is slightly broadened; the posterior portion of the ceratohyal is not clearly discernible; the epihyal is triangular. The interhyal is not recognizable. A few branchiostegal rays are visible (Fig. $5 \mathrm{c} 1$ ), but the total complement of branchiostegal rays cannot be specified.

Branchial arches-The individual bones of the branchial skeleton are not identifiable. The pharyngeal teeth are relatively robust; some of the teeth are pointed, others are blunt.

Vertebral column-There are 28 vertebrae, of which 10 are abdominal. Vertebral centra are constricted in the middle; centrum length exceeds the centrum height. The parapophyses are well developed. The length of the abdominal part of the vertebral column corresponds to approx. 50\% of the length of the caudal part. The haemal spine of the first caudal vertebra is somewhat shorter than those behind it; all the haemal spines are more or less equally inclined (Fig. 5c2). Ribs are present from the second to the last abdominal vertebra; they are slender and relatively long. In the region of the ribs, a few slender epineural bones are visible. The supraneurals are absent.

Pectoral girdle and fins-Only the main body of the posttemporal is visible. The supracleithrum is elongate and narrow. The cleithrum is stout, long and only slightly curved; the coracoid is not preserved. Three radial bones, roundishto-square in shape, are preserved. The number of the pectoral-fin rays is 14 , but their full extents cannot be discerned.

Pelvic girdle and fins-The pelvic bone is located slightly anterior to the radials of the pectoral fin. The pelvic fins are not well preserved, but a spine and five soft rays are recognizable. The pelvic-fin rays are relatively thick and distally 
branched; their full lengths cannot be clearly traced, but they terminate at some distance from the anal-fin origin.

Dorsal fins-The D1 has six slender spines that taper into long filaments; the last spine is the shortest and lies quite close to the preceding one (3.0\% SL distance between them); the pterygiophore formula is 3-22110 (Fig. 7e). The D2 inserts distantly from the D1, above the second caudal vertebra (Fig. 5c2). It consists of a slender spine that narrows to a long filament and 16 segmented and branched rays; the posteriormost rays end above the first two procurrent caudalfin rays (Fig. 8c).

Anal fin-The anal fin inserts below the second caudal vertebra. It comprises a thin, straight and short spine (3.5\% SL) and 15 segmented and branched rays; the posteriormost rays terminate opposite to the first two procurrent caudal-fin rays (Fig. 8c). The number of the anal-fin pterygiophores inserting anterior to the haemal spine of the first caudal vertebra is not clear, but seems to be two.

Caudal endoskeleton and fin-The caudal fin is longish (32.6\% SL) and probably lanceolate. It is composed of 17 segmented principal rays; 9 principal rays are present in the upper lobe. Six procurrent rays occur both dorsally and ventrally. The caudal skeleton has two large hypural plates $(\mathrm{HY} 1+2$ and HY3 +4), of which the upper is fused with the terminal centrum; hypural 5 is slender. Due to the dense scale cover, neither the parhypural nor epural are recognizable. The neural spine of PU2 is shorter than the preceding spines and seems to be duplicated. The haemal spine of PU2 is long, plank-like, and oriented obliquely to the caudal fin, where it supports two or three principal caudal-fin rays; an additional (duplicated) shorter haemal spine occurs slightly behind the middle of the PU2 centrum (Fig. 8c).

Otoliths-For measurements of the sagittae and lapillus, see Table 1, for the described characters, see Figs. 9f, g, 10e.

Sagitta: Inner (=medial) face flat to weakly convex; outer (=lateral) face convex, with rounded hump located at and slightly above the centre; general shape squarish-to-ventrally rounded; ventral portion wider than dorsal portion; dorsal margin weakly convex and slightly rising posteriorly; no preventral or posterodorsal (or any) projections; ventral line deep and extending up to the sulcus tip and sulcus end, respectively; deep dorsal depression extending to the dorsal margin; sulcus very slightly inclined, with wide ostium and elongate cauda; cauda shorter than ostium, with roundish and very thick subcaudal iugum.

The right and left sagittae show some asymmetry, the dorsal margin being slightly more ascending in the right than in the left sagitta, while the posteroventral margin is asymmetrically curved in the right, but regularly curved in the left sagitta, and the length/height ratio also differs between the two (0.99 in the right, 1.06 in the left sagitta).

Lapillus: The single preserved right lapillus is rounded to ovate; in ventral view it shows a clear cranial suture, curved sulculus, and a more or less V-shaped linea basalis on the posterior half; in lateral view, it is wedge-shaped, with the thickest part lying posteriorly.

Scales-All scales are ctenoid. Flank scales are relatively large, their shape is mostly ovate, and a slight protuberance can occur in the middle of the posterior margin (Fig. 11c). The scale surface is relatively smooth, apart from the thickened posterior margin; several circuli and five weak radii can be observed. Scales above the anal fin display relatively long ctenii; scales beneath the D2 seem to have shorter ctenii. Scale number in the longitudinal row is about 45. Predorsal and belly scales are round, thin and noticeably smaller than the flank scales. Scales also cover the base of the caudal-fin rays (Fig. 8c).

$\uparrow$ Sarmatigobius iugosus (Schwarzhans, Brzobohatý and Radwańska, 2020) comb. nov.

Figures 5d, 6c, 7d, 9h

* 2020 Hesperichthys iugosus Schwarzhans, Brzobohatý and Radwańska: p. 161, pl. 9, figs. 13-14 [otoliths only].

Material examined. Specimen PIN 5274/38a, b, approx. $64 \mathrm{~mm}$ SL; preserved as part and counterpart; part fragmented and highly incomplete; counterpart (Fig. 5d) with well preserved head exposing a left sagitta in situ (right sagitta has been extracted and is shown in Fig. 9h) and relatively well preserved anterior half of the body.

Locality and age. Karpov Yar, Naslavcea, northern Moldova; lower Sarmatian.

General description. Medium-sized gobiid fish; approx. $64 \mathrm{~mm}$ SL; body and head preserved in lateral view. Body elongate and slender; head of moderate size (21.7\% SL); body depth at origin of anal fin $11.9 \%$ SL; base of D2 relatively long $(34.8 \% \mathrm{SL})$; pectoral fin of moderate length (15.1\% SL). For further body proportions and meristic counts, see Table 1.

Neurocranium-The neurocranium is preserved roughly in lateral view and seems to be moderately deep. The eyes are relatively large; horizontal diameter of the orbit almost equals the snout length. The long frontal bones are oriented almost horizontally to the body axis over the orbit; they are 
relatively narrow between the orbits and become broader posteriorly. The parasphenoid borders the lower margin of the orbit; it is straight, relatively narrow, with a broad posterior portion. The vomer is recognizable, and is rounded anteriorly. The ethmoid part of the neurocranium is relatively short. Head scales are not recognizable.

Jaws - The mouth gape is moderately wide; the lower jaw articulation is situated slightly anterior to the middle of the orbit (Fig. 5d). The maxilla is slender and elongate, slightly broader posteriorly and somewhat bent in its anterior portion. The premaxilla has a very thin ascending process, a broader articular process and a moderately developed postmaxillary process. Premaxillary teeth are slender, small, conical, differ somewhat in size and are multiserial. The dentary is narrow and long, it has a moderately developed coronoid process; the dentary bears both large ('caniniform') and small slender conical teeth (Fig. 6c). The anguloarticular is moderately deep at the retroarticular process.

Suspensorium, opercular apparatus and hyoid arch-Not all of the suspensorium bones are readily recognizable. The symplectic is a robust rod in its lower portion; the remains of the metapterygoid are preserved. The quadrate is a roughly triangular bone with a deep and wide indentation in its posterior portion and a strong, thick and pointed posterior process. The ectopterygoid is a relatively long bone, almost straight and tapered posteriorly. There is no entopterygoid. The palatine is T-shaped, its maxillary process is slightly bigger than its ethmoidal process (Fig. 6c); the palatine shaft is tapered posteriorly and it is not clear whether it reaches the quadrate. The preopercle is strongly curved and crescent-shaped. The opercle is triangular and tapered ventrally; the subopercle is slightly larger than the opercle, whereas the interopercle is not recognizable. The hyoid bar (ceratohyal + epihyal) is relatively straight; the anterior portion of the ceratohyal is slightly broadened, while its posterior portion is not clearly visible; the epihyal is triangular. The interhyal is not recognizable. A few branchiostegal rays are visible (Fig. 5d), but their total number cannot be determined.

Branchial arches-The individual bones of the branchial skeleton are not identifiable. Both thin, cylindrical and sharp, as well as large, cylindrical and somewhat blunt teeth are recognizable in the pharyngeal jaws.

Vertebral column-Ten abdominal vertebrae are present, but the total number of vertebrae is not definable because of the incompleteness of the specimens. The vertebral centra are somewhat elongated and constricted in the middle; the vertebral spines are moderately long and almost straight. Ribs are slender and relatively long; these are strongly inclined posteriorly. Only a few of the slender epineurals are partially preserved.

Pectoral girdle and fins-Only the main body of the posttemporal is visible. The supracleithrum is elongate and narrow. The cleithrum is stout, long and only slightly curved; the coracoid is not preserved. The radial bones are poorly preserved; the number of pectoral-fin rays is at least 12 , and they are moderately long $(15.1 \% \mathrm{SL})$.

Pelvic girdle and fins-The pelvic girdle is not preserved. The pelvic-fin rays are disarticulated, relatively thick and distally branched.

Dorsal fins-The D1 contains six slender spines (Figs. 5d, $7 \mathrm{~d}$ ), of which at least the four anteriormost ones taper distally into filaments; the last spine is shortest and close to the preceding one $(3.3 \% \mathrm{SL})$; the pterygiophore formula is not recognizable. The $\mathrm{D} 2$ is widely separated from the D1 (Figs. 5d, 7d), with a vacant interneural space between them; the D2 has a relatively robust, straight spine, its posterior part is missing because of incomplete preservation, but the number of soft rays is definitely relatively high.

Anal fin-The anal fin is not completely preserved, but the number of its rays seems to be relatively high.

Caudal endoskeleton and fin-Details of the caudal fin are not recognizable, owing to the fragmentary preservation.

Otoliths-For measurements, see Table 1, for the described characters, see Fig. 9h. The species-specific characters of the sagitta include a somewhat depressed dorsal margin that bears a rounded protuberance at its posterior end, and the occurrence of a prominent and relatively long subcaudal iugum. All other characters are as described above for $\dagger S$. compactus gen. et sp. nov.

Scales - The scales appear to be cycloid, but minute spinules are dispersed through the body, and may represent ctenii that were originally loosely connected to the scale margins. The flank scales are relatively large; the belly scales are smaller than the flank scales; scales also overlie the base of the caudal-fin rays. Predorsal scales are smaller than the flank scales, very thin and cycloid.

Remark. See differential diagnosis for $\dagger S$. compactus gen. et sp. nov. for differences between the two species.

Genus $†$ Yarigobius gen. nov.

Type species. †Yarigobius decoratus gen. et sp. nov. (Figs. 5f, 7f, 8d, 9k, 1, 10f,g, 11d). 
Other species. †Yarigobius naslavcensis gen. et sp. nov. (Figs. 5e, 7g, 8e, 9i, j, 11e).

Etymology. The generic name refers to the locality in which this new genus was discovered (Karpov Yar, Moldova) and its general similarity to members of the family Gobiidae. Gender masculine.

LSID ZooBank. This new genus is registered under urn:lsid:zoobank.org:act:DEE7C882-8602-4E54-B9582E5AB7FE631B.

\section{Stratigraphic range. Lower Sarmatian.}

Diagnosis. Relatively small to medium-sized gobiid fish, 38.7 to $63.2 \mathrm{~mm}$ SL; head moderately large (23.7-24.3\% SL); body probably laterally compressed (as preserved in lateral view); body depth at origin of D1 is comparatively large (21.4-21.7\% SL); pre-anal distance relatively long (54.3$58.0 \% \mathrm{SL}$ ); anal fin inserted one to two vertebrae behind insertion of D2; anal-fin base relatively short (23.2-25.3\% SL); pelvic fins relatively long (20.9-22.9\% SL); pelvic-fin spine relatively short (4.6-5.2\% SL and 35-36\% of adjacent ray); relatively long caudal part of vertebral column (52.7$53.5 \%$ SL) and caudal peduncle (19.4-23.3\% SL); caudal fin lanceolate and about as long as head (25.0\% SL). Number of vertebrae 28-29 (10+18-19). Dorsal fins widely separated. D1 with six or seven slender, distally filamentous spines; D1 pterygiophore formula starting with a single first pterygiophore $(3-1 \ldots, 2-1 \ldots)$; D2 with one spine and 14-16 segmented rays; anal fin with one spine and 13-14 segmented rays. Pectoral fin with about 15 rays (not clearly discernible). Pelvic fins with spine and five rays; pelvic rays end some distance from anal-fin origin. Caudal fin with 16 to 17 segmented rays, eight to nine rays in the upper lobe. Scales cycloid (type species) or ctenoid. In addition, the following characters of the saccular otoliths (sagittae) are, in combination, diagnostic for this genus: sagitta shape rounded-to-rectangular, with ventral portion being slightly wider than dorsal portion; weakly pronounced, rounded posterodorsal and preventral projections and slightly protruding posteroventral portion; ventral margin slightly undulated; shallow, clearly delimited dorsal depression; sulcus of 'shoe-sole' shape, moderately to distinctly inclined ( $\left.\alpha=6.5-18.5^{\circ}\right)$; clear separation into elongate ostium and short cauda. Lapillus with almost straight dorsal side and moderately convex ventral side; ovate shape in ventral view; shape in lateral view is elongate anteriorly and rounded-to-rectangular posteriorly.

Differential diagnosis. The most phenotypically similar genera with respect to the presence of a longish caudal fin, high number of rays in the D2 and anal fin, and the general proportions of head and body are Lesueurigobius Whitley, 1950 and the three other new fossil genera described in this study, i.e., †Katyagobius gen. nov., †Pseudolesueurigobius gen. nov., and $†$ Sarmatigobius gen. nov. (see Table 1 for data on the fossils and Appendix Table for data on Lesueurigobius). The presence of a slightly longer caudal part of the vertebral column (52.7-53.5\% SL vs. 49.2-50.5\%\% SL) and a pterygiophore formula starting with a single pterygiophore (vs. two) differentiates $\nmid$ Yarigobius gen. nov. from these genera. A further diagnostic character of $\dagger$ Yarigobius gen. nov. is a rounded-to-rectangular sagitta with slight posterodorsal and preventral projections (vs. no projections in the sagittae of the other fossil genera [see Fig. 9], and vs. a well developed posterodorsal portion or projection in Lesueurigobius [see Fig. 12]). Also the lapillus shape is distinctive, when compared to the other new fossil genera (see Fig. 10). The lapillus shows similarity to the lapillus of Gobius (Fig. 10h) in both ventral and lateral view, but the dorsal side is straight in $†$ Yarigobius gen. nov. (vs. convex in Gobius).

Further characters of $\dagger$ Yarigobius gen. nov. that differentiate it from $\dagger$ Katyagobius gen. nov. include: greater body depth at origin of D1 (21.4-21.7\% SL vs. 17.7-18.5\% SL); slender D1 spines (vs. robust); slightly longer pelvic fins (20.9-22.9\% SL vs. 16.1-17.1\% SL); relatively shorter pelvic-fin spine (4.6-5.2\% SL $+35-36 \%$ of adjacent ray vs. 6.0-6.5\% SL + 56-66\% of adjacent ray). Characteristics of $\dagger$ Yarigobius gen. nov. that separate it from $†$ Pseudolesueurigobius gen. nov. are its 18-19 caudal vertebrae (vs. 17) and a relatively shorter caudal fin (25.0\% SL vs. 33.4-33.8\% SL). Traits that distinguish $†$ Yarigobius gen. nov. from $\dagger$ Sarmatigobius gen. nov. are the relatively longer preanal distance (54.3-58.0\% SL vs. 47.9\% SL); relatively shorter anal-fin base (23.2-25.3\% SL vs. 28.6\% SL); and an anal fin that is inserted 1.5-2 vertebrae behind the insertion of the D2 (vs. opposite).

†Yarigobius decoratus gen. et sp. nov. Figures 5f, 7f, 8d, 9k, 1, 10f, g, 11d

Type material. Holotype, PIN 5274/76a, b, $63.2 \mathrm{~mm}$ SL. Well preserved part and slightly damaged counterpart, with left and right otoliths (sagittae and lapilli) preserved in situ.

Type locality and age. Karpov Yar, Naslavcea, northern Moldova; lower Sarmatian.

Etymology. The species name refers to the presence of some enlarged cycloid scales on the posteriormost portion of the body, which appear to 'decorate' the fish.

LSID ZooBank. This new species is registered under urn:1sid:zoobank.org:act:14ED4CB9-F03D-4122-B2F85DD41EFFD94E. 
Diagnosis. Differentiated from the only other species of this genus currently known, $† Y$. naslavcensis gen. et sp. nov. by a relatively shorter lower jaw (7.9\% SL vs. $10.3 \%$ SL); a longer caudal peduncle (23.3\% SL vs. $19.4 \%$ SL); a greater body depth at the origin of the anal fin $(20.6 \%$ SL vs. $16.8 \%$ SL); a wider separation between D1 and D2 (9.5\% SL vs. 4.7\% SL); six D1 spines (vs. seven); and presence of cycloid scales (vs. ctenoid), some of which are enlarged. The sagitta of $\dagger Y$. decoratus gen. et sp. nov. is longish (vs. slightly higher than long in $\dagger Y$. naslavcensis) and its posteroventral protrusion is slightly angular (vs. rounded).

General description. Medium-sized gobiid fish; $63.2 \mathrm{~mm}$ SL (Fig. 5f). The body is preserved in lateral view and moderately elongate; the head is seen in dorsolateral view and moderately large $(23.7 \% \mathrm{SL})$; the D2 inserts one vertebra before the anal fin; the caudal peduncle is relatively long (23.3\% SL); the caudal fin is longish and about as long as the head $(25.0 \% \mathrm{SL})$. For further body proportions and meristic counts, see Table 1.

Neurocranium-The neurocranium is preserved in dorsolateral view; it is relatively deep, but most of its bones are not sufficiently well preserved to be described. The parasphenoid is straight, relatively narrow, with a broad posterior portion; it borders the lower margin of the apparently relatively large orbit. The vomer is not clearly recognizable. The ethmoid part of the neurocranium is relatively short. Head scales are either not present or not preserved.

Jaws - The lower jaw is of moderate length (7.9\% SL); the lower jaw articulation is situated slightly behind the middle of the orbit. The maxilla seems to be slender and moderately expanded posteriorly. The premaxilla is a robust bone, with a moderately slender ascending process and a wide articular process. The dentition comprises both large and small conical teeth.

Suspensorium, opercular apparatus and hyoid arch-The suspensorial bones are poorly preserved and hardly recognizable. The opercular bones are not completely preserved; the preopercle is rather slender and slightly curved, the opercle is roughly triangular and the subopercle is elongate. The hyoid bars are poorly visible; five branchiostegal rays are recognizable, of which the first is very slender, whereas the others are strong.

Branchial arches-The individual bones of the branchial skeleton are hardly identifiable. The pharyngeal jaws are robust and their dentition is represented by relatively large, stout, and blunt teeth as well as by long, slender, conical, pointed teeth.
Vertebral column-There are 29 vertebrae, of which 10 are abdominal (only 9 abdominal vertebrae are recognizable, but based on the space between the first visible centrum and the basioccipital it can be assumed that the anteriormost vertebra is not preserved). The vertebral centra are constricted in the middle; the centrum length is slightly longer than the centrum height. The parapophyses are clearly recognizable in the posterior abdominal vertebrae. The length of the caudal part of the vertebral column is $53.5 \% \mathrm{SL}$; the length of the abdominal part of the vertebral column is equivalent to $49.1 \%$ of the caudal part. The haemal spine of the first caudal vertebra is slightly shorter than those of the following caudal vertebrae (Fig. 5f); all the haemal spines are equally inclined, apart from the spines of preural vertebrae 2 and 3 , which are more strongly inclined. Ribs are slender and moderately long; ribs extend from the third to the last abdominal vertebra. In the region of the ribs, a few epineural bones are visible. The supraneurals are absent.

Pectoral girdle and fins-The pectoral girdle is slightly disarticulated. The posttemporal has a relatively broad body and long, slender processes. The cleithrum is relatively broad, long and only slightly curved, and a small triangular coracoid is present. The pectoral fin is not preserved.

Pelvic girdle and fins - The basipterygium is somewhat triangular. The pelvic fins seem to be close to each other, their length is about $22.9 \%$ SL. Each pelvic fin contains a relatively short spine (5.2\% SL, 35.8\% of the adjacent ray) and five rays that are highly segmented and branched distally; proximally they seem to be unsegmented. The rays terminate at some distance from the origin of the anal fin (Fig. 5f).

Dorsal fins-The D1 has six slender spines (Figs. 5f, 7f), which taper gradually into especially slender filaments; the last spine is the shortest, lies slightly distant from the preceding one and much further $(9.5 \% \mathrm{SL})$ from the D2 spine. The pterygiophore formula seems to be 3-13110 (visible in the counterpart), but the neural spine of the fifth vertebra is slightly distorted and the formula could also be 3-12210. The D2 inserts above the second caudal vertebra. It consists of a slender spine with a short filament, and 16 segmented and branched rays; the first soft rays have about the same length, the posterior ones become longer and form a slightly pointed lobe; their distal ends terminate above the anterior procurrent caudal-fin rays.

Anal fin-The anal fin inserts below the third caudal vertebra, i.e., one vertebra behind the origin of the D2. It comprises one relatively long $(6.3 \% \mathrm{SL})$, slender, slightly curved spine and 14 rays. Overall, the anal fin is similar in shape and size to the D2 (Fig. 5f); the posteriormost rays of the anal fin also reach the caudal-fin origin; they terminate 
opposite to the first two procurrent caudal rays (Figs. 5f, 7d). The spine is supernumerary on the first pterygiophore. This pterygiophore seems to be the only one that inserts before the haemal spine of the first caudal vertebra.

Caudal endoskeleton and fin-The caudal fin is wide, of moderate length $(25.0 \% \mathrm{SL})$ and longish to lanceolate. It is composed of 17 segmented principal rays, the outermost rays are unbranched; 9 principal rays are found in the upper lobe. Six procurrent rays are present both dorsally and ventrally, and display their forked bases (Fig. 8d). The caudal skeleton comprises two large hypural plates $(\mathrm{HY} 1+2$ and HY3 +4 ), of which the upper is fused with the terminal centrum; hypural 5 is slender. The parhypural is relatively long and does not reach the terminal centrum; the epural seems to be very broad. The neural spine of PU2 is slightly broader and shorter than the preceding spines. The haemal spine of PU2 is long and distally expanded (Fig. 8d).

Otoliths-For measurements of the sagitta and lapillus, see Table 1, for the described characters, see Figs. 9k, 1, 10f, g.

Sagitta: Inner (=medial) face flat; outer (= lateral) face convex, with roundish hump situated in the central and posteroventral region; general shape of sagitta longish-torectangular with rounded, relatively small posterodorsal and preventral projections; ventral portion of sagitta slightly wider than the dorsal; dorsal margin highest in its posterior third, smoothly declining anteriorly; posterior margin indented; ventral margin slightly undulated; ventral line relatively broad and shallow, its anterior portion terminates close to the sulcus tip, its posterior part ends somewhat distant from the sulcus end; dorsal depression shallow and clearly delimited from dorsal margin; sulcus of 'shoe-sole' shape and moderately inclined $\left(\alpha=6.5-8.5^{\circ}\right)$; ostium longer than cauda; ostium with rounded-to-triangular dorsal lobe near the transition to the cauda and weakly curved ventral lobe; cauda relatively short and roundish.

The right and left sagittae (of the holotype) show slight asymmetry: the anterodorsal margin exhibits a small angular projection (right sagitta) or is weakly rounded (left sagitta); the anterior margin is notched (right sagitta) or faintly concave (left sagitta); and the crenulation of the ventral margin is mainly in the anterior half (right sagitta) or in the middle (left sagitta).

Lapillus: Both lapilli are preserved in the holotype. In ventral view their shape is ovate; a cranial suture and a curved sulculus are well developed; a well-defined linea basalis extends across the posterior half of the lapillus; the shape of the linea basalis is V-like, with a longer and slightly undulating medial part and a shorter lateral segment. In lateral view, the lapilli present a slightly sinuous lateral margin and a slender anterior portion; the remaining portion of the dorsal side is straight and that of the ventral side is moderately convex.

Scales-All scales are cycloid. The relatively large flank scales are thickened along their posterior margin and exhibit a rounded angle in the middle of the posterior border; overall their shape is aliform (Fig. 11d3). About 6-7 radii extend from the focus, which is located in the posterior part of the scale, to the anterior scale margin (Fig. 11d1). Above and below the radii the scale is relatively smooth and numerous circuli are visible. The scale number in longitudinal row is about 40. At the dorsal and ventral margins of the posterior caudal peduncle, a few enlarged scales are present (Figs. 5f, $8 \mathrm{~d}, 11 \mathrm{~d} 2$ ); they seem to lack any radii. The predorsal scales are very small; the belly scales are rounded, thin and smaller than the flank scales. Scales also cover the base of the caudal-fin rays (Fig. 8d).

Coloration-The holotype reveals a dense, dark pigmentation in the distal portions of the dorsal, anal and pelvic fins. The most prominent pigmentation is present on the anal fin (Fig. 5f).

$\dagger$ Yarigobius naslavcensis gen. et sp. nov.

Figures 5e, 7g, 8e, 9i, j, 11e

Type material. Holotype, PIN 1306/71, 38.7 mm SL; an almost complete, well-preserved specimen in a single plate, end of caudal fin missing; both sagittae preserved in situ (lapilli not preserved).

Type locality and age. Karpov Yar, Naslavcea, northern Moldova; lower Sarmatian.

Etymology. The species is named after the township Naslavcea, Moldova, in the vicinity of the type locality.

LSID ZooBank. This new species is registered under urn:1sid:zoobank.org:act:35847C32-4BEA-4FC1-A06F686C41869B41.

Diagnosis. As for genus. Differentiated from the only other species currently known, $\dagger Y$. decoratus gen. et sp. nov. by a relatively longer lower jaw (10.3\% SL vs. $7.9 \%$ SL), a shorter caudal peduncle (19.4\% SL vs. $23.3 \%$ SL), a smaller body depth at the origin of the anal fin $(16.8 \%$ SL vs. $20.6 \%$ SL), a shorter distance between D1 and D2 (4.7\% SL vs. 9.5\% SL), seven D1-spines (vs. six) and the presence of ctenoid scales (vs. cycloid), with no enlarged scales. The sagitta of $\dagger Y$. naslavcensis gen. et sp. nov. is slightly higher than long (vs. longish in $\dagger Y$. decoratus) and its posteroventral protrusion is rounded (vs. slightly angular). 
General description. Relatively small gobiid fish of $38.7 \mathrm{~mm}$ SL (Fig. 5e); the body is elongate, only slightly tapering posteriorly; probably laterally compressed (as preserved in lateral view); the head is of moderate size ( $24.3 \% \mathrm{SL})$; the anal fin inserts two vertebrae behind D2; the caudal peduncle is moderately long (19.4\% SL). For further body proportions and meristic counts see Table 1 .

Neurocranium-The neurocranium is deep; the eyes are relatively large $(5.9 \% \mathrm{SL})$, and the ethmoid region very short. The frontal bones are long and oriented obliquely to the body axis over the orbit, narrow between the orbits and broad posteriorly. The parasphenoid is a straight, thin rod with a broad posterior portion; the vomer is recognizable, but its shape is not clear. The ethmoid region is short. Whether scales are present on the head cannot be decided.

Jaws - The lower jaw is relatively long (10.3\% SL); the jaw joint is located opposite the middle of the orbit (Fig. 5e). The dentary is narrow anteriorly and becomes deeper posteriorly; it bears at least two rows of variously sized teeth. The anguloarticular has a relatively strong retroarticular process; the groove in which the Meckelian cartilage lay is traceable. The upper jaw bones are damaged; the preserved parts of the premaxilla bear a postmaxillary process; the maxilla is not preserved. Some slender and conical premaxillary teeth are recognizable.

Suspensorium, opercular apparatus and hyoid arch-The suspensorium and opercular bones are poorly preserved. The symplectic is a robust rod. Five branchiostegal rays are preserved in almost anatomical connection with the hyoid bar; the shape of the hyoid bar is unclear.

Branchial arches-Most of the bones of the branchial skeleton are not identifiable. The large pharyngeal jaws bear slender, pointed teeth of slightly different sizes.

Vertebral column-There are 28 vertebrae, of which 10 are abdominal. The vertebral centra are constricted in the middle; the centrum length is slightly longer than the centrum height. Only a few parapophyses are recognizable. The length of the abdominal part of the vertebral column is $52.7 \%$ that of the caudal part. The first caudal vertebra bears a haemal spine that is slightly inclined towards the following haemal spine, but is as long as the other haemal spines (Fig. 5e); all the haemal spines are more or less equally inclined. At least eight pairs of slender ribs are present; the first six pairs are moderately long, and the last two pairs are relatively short; tiny epineurals are also present. Supraneurals are absent.
Pectoral girdle and fins-The posttemporal is incompletely preserved. The cleithrum is robust, long and only slightly curved. Only the slightly displaced base of the pectoral fin is preserved; the number and length of its rays are unknown.

Pelvic girdle and fins-The length of the pelvic fins is $20.9 \%$ $\mathrm{SL}$; the pelvic-fin spine length is $4.6 \% \mathrm{SL}$; the pelvic-fin rays terminate distant from the anal-fin origin.

Dorsal fins-The D1 contains seven slender spines (Figs. 5e, $7 \mathrm{~g}$ ); spines I-V taper into short filaments; spine II is the longest (13\% SL); spines I and III are slightly shorter (98.4\% of spine II), while the subsequent spines decrease in length posteriorly $(89 \%, 67 \%, 42 \%$ and $17 \%$ of spine II, respectively). The gap between spines $\mathrm{V}$ and VI is relatively long $(4.6 \% \mathrm{SL})$ and 2.2 times greater than that between spines IV and V. The pterygiophores of the D1-spines IV and V are displaced, but the formula clearly begins with $2-1 \ldots$. The D2 inserts opposite to the first caudal vertebra. It consists of a relatively thin, long $(9.0 \% \mathrm{SL})$ and slightly curved spine (whether it tapers into filaments is not clear) and 14 segmented and branched rays. The D2-rays are incomplete posteriorly; perhaps they become progressively longer posteriorly, as some of the posterior rays seem to reach the first procurrent caudal rays.

Anal fin-The anal fin inserts below the third caudal vertebra, i.e., two vertebrae behind the origin of D2. It comprises a moderately long, thin spine (4.9\% SL) and 13 rays; most of the rays have about the same length and it is not clear whether their distal ends extend to the caudal-fin origin. The pterygiophores of the anal-fin spine and anterior rays are not recognizable.

Caudal endoskeleton and fin-Only the proximal portion of the caudal fin is preserved; therefore, its shape cannot be determined. Based on its preservation, it is unclear if the caudal fin contains 17 principal rays (with eight rays in the lower lobe) or 16 principal rays (assuming the uppermost ray split longitudinally post-mortem). Seven and six procurrent rays are present dorsally and ventrally, respectively; some of them display their forked bases. The caudal skeleton comprises two large hypural plates (HY1 +2 and HY $3+4)$, of which the upper is fused with the terminal centrum (Fig. 8e); hypural 5 is about half the length of HY $3+4$ and thin. The epural is slightly curved, elongate and relatively large; the parhypural is relatively long, narrow and closely associated with the widened haemal spine of the second preural vertebra (PU2); the neural spine of PU 2 seems to be short.

Otoliths - The holotype of this species retained both sagittae in situ, but no lapilli. There is a notable asymmetry between the right and left sagittae, as described below. For 
measurements see Table 1, for the described characters see Fig. 9i, j.

Sagitta: Inner (=medial) face flat; outer (= lateral) face convex, with centrally located bulge accounting for about $50 \%$ of the sagitta height; general sagitta shape more or less squarish-to-rounded, with curved, weakly developed posterodorsal bulge (more prominent in the left sagitta) and small preventral projection; ventral portion of sagitta slightly wider than dorsal portion; dorsal margin regularly curved (left sagitta) or highest posteriorly and slightly indented in the middle (right sagitta); below the posterodorsal bulge is a V-shaped incision, followed by the curved ventral portion of the posterior margin; ventral margin slightly crenulated, almost straight in the middle, otherwise weakly curved; anterior margin faintly rounded (left sagitta) or with a few knobs (right sagitta); ventral line well developed; its anterior end almost reaches the ostium tip, its posterior end terminates distant from the cauda end; dorsal depression longish and shallow; sulcus of 'shoe-sole' shape and clearly inclined ( $\alpha=15.5-18.5^{\circ}$ ); ostium smoothly curved; cauda longish and terminally rounded; in the right sagitta the cauda is distinctly narrower than in the left sagitta; a thin crista superior and a thin crista inferior surround both the ostium and cauda; the crista inferior is especially well developed along the cauda.

Scales-Scales are relatively thin; scale cover is dense (Figs. 5e, 11e1). The flank scales are ctenoid and circular or ovate (Fig. 11e2-3); ctenii are short, number of radii appears to be seven. Scale number in longitudinal row is about 41. The predorsal and belly scales are smaller than the flank scales; whether ctenii are present is not clear. Thin scales also cover the base of the caudal-fin rays (Fig. 8e).

\section{Discussion}

\section{Relationships between the new genera and remarks on taxonomy}

With respect to most of their morphometric, meristic and osteological characters, $†$ Katyagobius gen. nov., $† P s e u-$ dolesueurigobius gen. nov., †Sarmatigobius gen. nov. and $\dagger$ Yarigobius gen. nov. are very similar to each other (Table 1). More specifically, they share the following suite of characters: ten abdominal vertebrae, a total vertebrae number that varies from 27 to 29 ; two relatively to strongly widely spaced dorsal fins; distally filamentous spines of the first dorsal fin; a spine and 14-16 soft rays in the D2; a spine and 13-15 soft rays in the anal fin; a longish-to-lanceolate caudal fin; and rounded, trapezoid-to-squarish sagittae without prominent (or any) projections and a ventral part that is slightly wider than the dorsal part. This combination of morphological traits is unique among the Gobioidei (see below). Thus, on the basis of the morphological evidence at hand, it can be assumed that $\dagger$ Katyagobius gen. nov., $\dagger P s e u-$ dolesueurigobius gen. nov., †Sarmatigobius gen. nov. and $\dagger$ Yarigobius gen. nov. form a monophyletic group.

Why then have we chosen to introduce four new genera to accommodate the six species described here, rather than assigning them all to a single genus? The answer is that, despite their superficial similarity, these fossil species differ from each other in several skeletal characters that are usually constant within a gobioid genus (e.g., Miller 1986, 2004; Birdsong et al. 1988; Murdy 1989; Hoese and Gill 1993; Pezold 1993; McKay and Miller 1997; Ahnelt 2003; Ahnelt and Duchkowitsch 2004; Hoese and Larson 2005).

i. While all the new species have 10 abdominal vertebrae, the number of the caudal vertebrae is 17 in $\dagger$ Pseudolesueurigobius gen. nov., 18 in $†$ Katyagobius gen. nov. and $†$ Sarmatigobius gen. nov., and 18-19 in $\dagger$ Yarigobius gen. nov.

ii. Two types of pterygiophore formulae can be distinguished. The type starting with a single pterygiophore in the interneural space $(2-1 \ldots, 3-1 \ldots)$ is shared by the two species of $†$ Yarigobius gen. nov.; the other type, starting with two pterygiophores in the interneural space $(3-2 \ldots)$, is shown by the other genera.

iii. The anal fin inserts opposite to D2 in $†$ Sarmatigobius gen. nov., but one to two vertebrae posterior to that in the other genera (Table 1).

iv. We also interpret the configuration of the D1-fin spines (unique in $†$ Katyagobius gen. nov.) and the length of the pelvic-fin spine (relatively longest in $\dagger$ Katyagobius gen. nov.) as genus-typical characters (Table 1).

In addition, the otoliths preserved in situ yield significant taxonomic information. As a rule, the sagitta of teleost species provides information at both generic and species level (Nolf 1985, 2013). In the Gobioidei, the sagittae of congeneric species are generally similar in overall shape; they share the same sulcus morphology and often show similar degrees of convexity/concavity of the outer and inner faces (e.g., Nolf 2013; Gierl et al. 2018; Gut et al. 2020; Schwarzhans et al. 2020a, b). However, the taxonomic interpretation of sulcus morphology, also in gobioid otoliths, is complicated by the fact that considerable variability can occur not only within a single species (unpublished data of BR, see also Fig. 12) but within the same specimen, as exemplified here by the right and left sagittae of $\dagger$ Yarigobius naslavcensis gen. et sp. nov. (see above and Fig. 9i1, j1). Therefore, we have used a combination of sulcus morphology, overall sagitta shape and the relative curvatures of the inner and outer 
Table 2 Compilation of vertebral counts in the lineages of the Gobiidae according to literature data

\begin{tabular}{|c|c|c|}
\hline Lineage & Genera & Vertebrae \\
\hline Aphia [2] (2) & Aphia, Lesueurigobius & $10+17$ \\
\hline Asterropteryx [5] (5) & Amblyeleotris, Asterropteryx, Ctenogobiops, Gladiogobius, Vanderhorstia & $10+16$ \\
\hline \multirow[t]{2}{*}{ Callogobius [5] (3) } & Barbuligobius & $9+17$ \\
\hline & Callogobius $^{\mathrm{V}+}$, Mangarinus & $10+16$ \\
\hline Cryptocentrus [10] (10) & $\begin{array}{l}\text { Cryptocentroides }^{\mathrm{v}+} \text {, Cryptocentrus, Discordipinna, Flabelligobius, Lotilia, Mahidolia, } \\
\text { Myersina, Psilogobius, Stonogobiops, Tomiyamichthys }\end{array}$ & $10+16$ \\
\hline \multirow[t]{4}{*}{ Glossogobius [4] (4) } & Bathygobius & $10+17$ \\
\hline & Glossogobius & $\begin{array}{l}\mathbf{1 0}+\mathbf{1 7} \\
11+16-17,12+16\end{array}$ \\
\hline & Psammogobius & $\mathbf{1 0}+\mathbf{1 8}, 11+17$ \\
\hline & Grallenia & $10+17-18$ \\
\hline \multirow[t]{2}{*}{ Gobiodon [13] (7) } & Bryaninops, Eviota ${ }^{\mathrm{V}+}$, Gobiodon ${ }^{\mathrm{V}+}$, Luposicya, Paragobiodon, Pleurosicya & $10+16$ \\
\hline & Kelloggella & $11+15$ \\
\hline Gobiopsis [27] (17) & $\begin{array}{l}\text { Acentrogobius }{ }^{\mathrm{V}+} \text {, Aulopareia, Cabillus, Drombus, Exyrias, Favonigobius }{ }^{\mathrm{V} 10+15} \text {, Gobiopsis, } \\
\text { Hazeus, Heteroplopomus, Istigobius, Macrodontogobius, Oplopomops, Opua, Parachaetu- } \\
\text { richthys, Porogobius, Silhouettea, Yongeichthys }\end{array}$ & $10+16$ \\
\hline Gobiosomatini [27] (22) & $\begin{array}{l}\text { Aruma, Barbulifer, Bollmannia, Chriolepis, Elacatinus, Eleotrica, Evermannichthys, Ginsbur- } \\
\text { gellus, Gobiosoma, Gobulus, Gymneleotris, Microgobius, Nes, Ophiogobius, Palatogobius, } \\
\text { Pariah, Parrella, Psilotris, Risor, Tigrigobius, Varicus, Vomerogobius }\end{array}$ & $\begin{array}{l}11+16-17 \\
12+15-17 \\
13+16-19 \\
14+17,15+20\end{array}$ \\
\hline \multirow[t]{7}{*}{ Gobius [27] (11) } & Caffrogobius ${ }^{\mathrm{V} 11+16}$, Coryogalops, Hetereleotris, Sufflogobius & $10+17$ \\
\hline & Gorogobius & $11+16$ \\
\hline & Gobius $^{\mathrm{V} 11+16}$, Mauligobius, Thorogobius, Vanneaugobius & $11+17$ \\
\hline & Benthophilus & $9+18-21,10+19-20$ \\
\hline & Anatirostrum & $9+20$ \\
\hline & Proterorhinus & $12-13+20-21$ \\
\hline & Neogobius & $12-13+21-22$ \\
\hline \multirow[t]{2}{*}{ Gunnellichthys [13] (9) } & Cerdale, Clarkichthys, Gunnellichthys, Microdesmus, Paragunnellichthys & $19-39+20-39$ \\
\hline & Nemateleotris, Oxymetopon, Parioglossus, Ptereleotris & $10-11+15-16$ \\
\hline \multirow[t]{2}{*}{ Kraemeria [3] (3) } & Gobitrichinotus & $14+16-17$ \\
\hline & Kraemeria, Parkraemeria & $10+16$ \\
\hline Lophogobius [5] (4) & Coryphopterus, Cristatogobius, Fusigobius, Lophogobius & $10+16$ \\
\hline Priolepis [10] (5) & Feia, Lythrypnus, Priolepis, Trimma, Trimmatom & $10+16$ \\
\hline Valenciennea [3] (3) & Amblygobius, Signigobius, Valenciennea & $10+16$ \\
\hline
\end{tabular}

Genera were sorted into lineages following Agorreta et al. (2013) and Thacker (2015). Vertebral counts were mainly compiled from Birdsong et al. (1988) and Miller (1986, 2004); additional counts were taken from Ahnelt (2003) [for Anatirostrum, Benthophilus], Ahnelt and Duchkowitsch (2004) [Proterorhinus], Shibukawa and Iwata (2007) [Grallenia], Kovačić and Schliewen (2008) [Gorogobius], and Hoese and Allen (2009) [Glossogobius]. [n], total number of genera included in the respective lineage; (n), number of genera for which vertebral counts were available from the respective lineage. Superscript $V[n+n]$ indicates the reported variation from the indicated count (according to Birdsong et al. 1988); V + indicates that the reported variation includes a count of $10+17$. Boldface refers to the three lineages whose vertebral counts partially or completely match the vertebral counts of the new extinct genera described in this study

faces to corroborate our generic interpretations (see generic diagnoses and descriptions above). On this basis, the sagittae of $\dagger$ Katyagobius gen. nov., $\dagger$ Pseudolesueurigobius gen. nov., $†$ Sarmatigobius gen. nov. and $\dagger$ Yarigobius gen. nov. are very different from each other, which is consistent with the assumption that the corresponding specimens belong to different genera rather than to different species.

The utricular otoliths (=lapilli) also exhibit characters that are phylogenetically informative at family and/or generic level, but—owing to the paucity of such characters-they are seldom suitable for species identification (Assis 2000, 2005; Schulz-Mirbach and Reichenbacher 2006; SchulzMirbach and Plath 2012). Fossil fishes with both sagittae and lapilli in situ, as in the present case, are exceptional finds (Assis 2005). Lapilli were recovered from four of the newly described species as well as from the two specimens of $\dagger$ Katyagobius sp. (Fig. 10). The study of their overall shape, thickness and especially of the curvature in lateral view revealed pronounced differences that provide strong additional support for the new genera described here. 
Thus, the preservation of both the sagittae and the lapilli in situ greatly contributed to the recognition of the taxonomic diversity of the specimens from Karpov Yar. The most striking examples of the relevance of the sagittae are the specimens PIN 1306/72 and 1306/81 (=†Pseudolesueurigobius manfredi gen. et sp. nov.). Without the sagitta preserved in situ, we would certainly have assigned them to the extant genus Lesueurigobius, with which they share a vertebral count of 10 abdominal +17 caudal vertebrae and almost all skeleton-based characters (Table 1; Appendix Table). However, the shapes and curvatures of the sagittae differ strikingly between $† P$. manfredi gen. et sp. nov. (Fig. 9e) and Lesueurigobius species (Figs. 9m, 12), which argues strongly against such a classification.

\section{Affinities of the new genera and species with previously described gobioids}

Most notably among the morphological characters of $\dagger$ Katyagobius gen. nov., †Pseudolesueurigobius gen. nov., $\dagger$ Sarmatigobius gen. nov. and †Yarigobius gen. nov. are the presence of distally filamentous spines in the first dorsal fin, large numbers of soft rays in both the D2 and anal fin, a longish or lanceolate caudal fin comprising 16-17 segmented principal rays, and rounded, trapezoid-to-squarish sagittae with a ventral portion that is slightly wider than the dorsal portion. This combination of characters clearly separates the new fossil genera and species from all previously described fossil skeleton-based gobioids (e.g., Arambourg 1927; Carnevale et al. 2006; Schwarzhans et al. 2012, 2017a; Gierl et al. 2013; Gierl and Reichenbacher 2015, 2017; Bannikov and Carnevale 2016; Reichenbacher et al. 2018, 2020; Bradić-Milinović et al. 2019), and also from all previously described otolith-based fossil gobioids (e.g., Nolf 2013; Agiadi et al. 2013, 2019; Bratishko et al. 2015; Lin et al. 2015, 2017; Schwarzhans et al. 2015,2020a, b; Reichenbacher et al. 2019; van Hinsberg and Helwerda 2019). Their distinctive combination of skeleton-related characters also differentiates the new fossil taxa from the extant members of the Gobioidei (e.g., Miller 1986, 2004; Carpenter et al. 1997; Carpenter and Niem 2001; Larson 2001; Murdy et al. 2002; Ahnelt 2003; Ahnelt and Duchkowitsch 2004; Kovačić 2008; Carpenter and De Angelis 2016), whereas otolith data are not available for every extant species or genus due to the extraordinary species richness of the Gobioidei.

Three fossil skeleton-based species from the marine lower Sarmatian of the Vienna Basin deserve special mention here, as they originate from more or less time-equivalent deposits representative of a similar environment. These species are $†$ Gobius elatus Steindachner, $1860, \dagger G$. oblongus Steindachner, 1860, and $\dagger$ G. viennensis Steindachner, 1860. Their re-examination is part of an ongoing project of BR, of which some results can be presented here. First of all, $\dagger G$. oblongus appears not to be a valid species because its original description is insufficient and the holotype is lost (see Schultz 2013). In contrast, the species named as $\dagger G$. elatus and $\dagger G$. viennensis are more or less well defined. However, low vertebral counts (24-26) clearly indicate that they do not represent the genus Gobius, which is characterized by the presence of 27-29 (mostly 28) vertebrae (Miller 1986; Birdsong et al. 1988; Table 2). Notably, $\dagger$ G. elatus and $\dagger G$. viennensis have similar numbers of soft rays in the D2 (13-14) as our new species. $\dagger G$. elatus also has 14 soft rays in the anal fin; in $\dagger G$. viennensis the anal fin is incomplete and it is only possible to confirm that it has at least 10 rays. However, the low vertebral counts of $\dagger G$. elatus and $\dagger G$. viennensis separate them from the new genera and species from Karpov Yar, which possess 27-29 vertebrae. This is further confirmed by the single sagitta preserved in situ in $\dagger$ G. elatus; its rectangular shape is very different from the sagittae found in the new species described here.

\section{Assignment of the new genera at higher systematic levels}

Extant Gobioidei can be divided into two groups, based on the presence of either five or six branchiostegal rays, namely a (paraphyletic) group whose members have six branchiostegal rays (6brG in the following) and a monophyletic group whose members possess five branchiostegal rays (5brG in the following); the loss of one ray is considered to be a synapomorphy for the latter (Akihito et al. 2000; Wang et al. 2001; Gill and Mooi 2012). The 5brG contain the families Gobiidae and Oxudercidae (nomenclature of Oxudercidae follows Nelson et al. 2016) and represent the most derived clade within the Gobioidei (Thacker 2009; Agorreta et al. 2013; Betancur et al. 2017). Apart from the presence of five branchiostegal rays, Gobiidae and Oxudercidae can usually be distinguished from the 6brG by further morphological characters including a T-shaped palatine bone (vs. L-shaped), absence of entopterygoid (vs. presence) and fused pelvic fins (vs. separated), however, some exceptions exist (Hoese 1984; Hoese and Gill 1993; Akihito et al. 2000; Gill and Mooi 2012).

Among the studied fossil specimens, the holotypes of $\dagger$ Katyagobius prikryli gen. et sp. nov., †Yarigobius decoratus gen. et sp. nov. and $\dagger Y$. naslavcensis gen. et sp. nov. each display a total of five branchiostegal rays, the first of which is very slender (Fig. 6a); in each of these three species the rays are preserved almost in anatomical connection with the hyoid bar. The number of branchiostegal rays could not be discerned in either $\uparrow P$ seudolesueurigobius gen. nov. or $\dagger$ Sarmatigobius gen. nov., but the head of $\dagger S$. iugosus revealed a palatine with an ethmoidal process almost as large as the maxillary process (Fig. 6c); such a shape corresponds to the $\mathrm{T}$-shape of the Gobiidae and Oxudercidae 
(see Reichenbacher et al. 2020: fig. 3). A T-shaped palatine is also preserved in $\dagger$ Katyagobius sp. (PIN 5274/35a) (Fig. 6b). Furthermore, the entopterygoid appears to be absent in each of the fossil specimens. The other derived character of the $5 \mathrm{brG}$ clade, the presence of fused pelvic fins, cannot be directly detected in a fossil because the fusion is produced by a membrane. Nevertheless, in $\dagger$ Pseudolesueurigobius manfredi gen. et sp. nov. and $\dagger$ Katyagobius sp. (PIN 5274/35a), the pelvic fins are close to each other, which may indicate that they were once fused together by a membrane (Fig. 6d). In conclusion, the presence of five branchiostegal rays, a T-shaped palatine, absence of the entopterygoid and possibly fused pelvic fins in the assembly of the four new genera enable them to be confidently assigned to the 5 brG clade (Gobiidae + Oxudercidae).

\section{Members of the Gobiidae or Oxudercidae?}

Among the characters that can be used to identify a fossil species either as a member of the Gobiidae or the Oxudercidae is the configuration of the palatine/ectopterygoid complex (palatopterygoquadrate complex in Harrison 1989; see also Thacker 2013; Reichenbacher et al. 2018). Unfortunately, the poor preservation of these bones in the specimens reported here makes any assignment impossible. Therefore, we inspected some additional characters that have been shown to be useful (often in combination) for the recognition of monophyletic groups within the Gobiidae or Oxudercidae in previous studies (e.g., Miller 1973, 1986, 2004; Rojo 1985; Birdsong et al. 1988; Pezold 1993, 2004; McKay and Miller 1997; Larson 2001; Larson et al. 2001; Murdy et al. 2002; Ahnelt 2003; Ahnelt and Duchkowitsch 2004; Vasil'eva and Bogorodskii 2004; Miller and Šanda 2008; Kramer et al. 2012; Vasil'eva and Vasil'ev 2016; Reichenbacher et al. 2018). Among these are the counts of abdominal, caudal and total vertebrae, the pterygiophore formula of the first dorsal fin, and the presence of one or two epurals in the caudal skeleton. Each of those characters can be evaluated in several of the new fossil species, and their condition is described below. We do not consider here the presence of a postmaxillary process on the premaxilla because this character is highly variable within both the Gobiidae and Oxudercidae (Miller 1973, 2004; McKay and Miller 1997; Vasil'eva and Kuga 2008; Thacker 2013).

1. The total number of vertebrae in the four new fossil genera ranges from 27 to 29 , and ten vertebrae make up the abdominal part of the vertebral column in all cases. $\dagger$ Pesudolesueurigobius gen. nov. has a configuration of $10+17$ vertebrae, $\dagger$ Katyagobius gen. nov. and $\dagger$ Sarmatigobius gen. nov. share a count of $10+18$ and $\dagger$ Yarigobius gen. nov. has $10+18-19$ vertebrae. This condition indicates an assignment to the Gobiidae, as the same vertebra counts are common for many Gobiidae, but only rarely occur in the Oxudercidae, which generally have lower or higher vertebrae counts (Miller 1986; Birdsong et al. 1988).

2. $\dagger$ Pesudolesueurigobius manfredi gen. et sp. nov., $\dagger$ Yarigobius decoratus gen. et sp. nov., and $\dagger Y$. naslavcensis gen. et sp. nov. each display a well-preserved caudal skeleton exhibiting a single epural (Fig. 6e). The presence of a single epural argues in favour of the Gobiidae, because the Oxudercidae usually have two epurals (Birdsong et al. 1988; Murdy 1989).

3. The pterygiophore formula of the D1 can provide useful taxonomic information at the level of family and lineages (Birdsong et al. 1988; Ahnelt and Duchkowitsch 2004; Miller 2004; Gierl et al. 2013). The pterygiophore formula 3-22110 was recognizable in three species, namely in $\dagger K$. prikryli gen. et sp. nov., $\dagger P$. manfredi gen. et sp. nov., and $\dagger S$. compactus gen. et sp. nov. This formula is a common configuration of many gobiid genera; among the Oxudercidae, it has only been reported for the genera Rhinogobius, Tridentiger, and Deltentosteus (Birdsong et al. 1988). But these three oxudercids can be excluded as potential relatives of our fossils because their meristic characters are clearly different: (i) Each has fewer soft rays in the anal fin: up to 9 in Rhinogobius; up to 11 in Deltentosteus; up to 12 in Tridentiger, vs. 13-15 in the studied fossils; (ii) Rhinogobius and Deltentosteus also have smaller numbers of soft rays in the D2: up to $10-11$ vs. $14-16$; (iii) their vertebral counts also differ from those of the fossils: $25-27$ in Rhinogobius; 26 in Tridentiger; 33 in Deltentosteus, vs. 27-29; and (iv) Tridentiger has tricuspid teeth in the oral jaws, vs. conical in the studied fossils (data from Miller 1986; Birdsong et al. 1988; Vasil'eva 2007; Boltachev and Karpova 2010; Froese and Pauly 2021).

In $\dagger$ Yarigobius gen. nov., the pterygiophore formula starts with an interneural space that is occupied by a single pterygiophore $(2-1 \ldots$ in $\dagger Y$. naslavcensis gen. et sp. nov.; $3-1 \ldots$ in $\dagger Y$. decoratus gen. et sp. nov.). The entire pterygiophore arrangement is not identifiable in $\dagger Y$. naslavcensis gen. et sp. nov., due to some post-mortem displacements. Nevertheless, its $2-1 \ldots$ pattern, i.e., the insertion of the first pterygiophore between the spines of the second and third vertebrae, is notable because the same configuration is only known from the Ponto-Caspian brackish water gobiid Proterorhinus marmoratus (Pallas, 1814) (see Ahnelt and Duchkowitsch 2004). But $P$. marmoratus has 12-13 abdominal vertebrae (vs. 10 in $\dagger Y$. naslavcensis gen. et sp. nov.), its total number of vertebrae is $31-33$ (vs. 28) and its common D2 formula is 16-17 (vs. 14) (see Ahnelt and Duchkowitsch 2004; Miller 2004). There are also some morphometric differences between the extant and the fossil species, including a relatively longer 
D2-base of P. marmoratus (36.6-43.1 vs. 31.5) and a slightly greater minimum caudal peduncle depth (10.7-13.2 vs. 8.8) (data from Miller 2004, based on P. marmoratus of similar SL [39.0-58.0 mm] as $\dagger Y$. naslavcensis gen. et sp. nov. [SL 38.7]). Unfortunately, the cranial bones are too poorly preserved in $\dagger Y$. naslavcensis gen. et sp. nov. to identify similarities or differences with the well-known cranial osteology of P. marmoratus (see Vasil'eva 1999; Miller 2004). Nevertheless, based on the aforementioned differences, we exclude a relationship between $P$. marmoratus and $\dagger Y$. naslavcensis gen. et sp. nov.

In $\dagger$ Yarigobius decoratus gen. et sp. nov., the pterygiophore formula of the D1 can be identified as either 3-13110 or 3-12210. Among the Gobiidae similar pterygiophore formulas (3-13100, 3-1221) are known only from the monotypic genus Aphia, i.e., from A. minuta (Risso, 1810) (Birdsong et al. 1988). Among the Oxudercidae, the 3-13110 formula occurs as a rare variant in Rhinogobius (which, as mentioned above, is definitely not related to any of the fossil genera), while the 3-12210 condition is common within both the Mugilogobius lineage (in Eugnathogobius [as Calamiana in Birdsong et al. 1988], Mugilogobius, Pseudogobiopis, Tamanka, Tasmanogobius) and the Stenogobius lineage (in Ctenogobius, Gnatholepis, Gobionellus, Oligolepis, Oxyurichthys, Stenogobius; Gobionellus Group sensu Birdsong et al. 1988: table 13). However, as outlined below, each of the aforementioned genera differs significantly in at least one of its morphological characters from $\dagger$ Yarigobius gen. nov., which makes a relationship unlikely.

i. Their usual vertebral count is $10+16$ (except in Tasmanogobius); a count of $10+18-19$, as in $\dagger$ Yarigobius gen. nov., is unknown among them (Birdsong et al. 1988). The vertebral counts of Tasmanogobius range from 26-32, and the number of abdominal vertebrae is 11-13 (Hoese 1991).

ii. Apart from Tasmanogobius and Gobionellus, none of the genera of interest here has more than 12 soft rays in the D2 (vs. 14-16 in †Yarigobius gen. nov.) (Hoese 1986b; Watson 1991; Larson 2001, 2009; Randall and Greenfield 2001; Pezold 2004; Larson and Buckle 2012; Pezold and Larson 2015).

iii. Two sagittae of Tasmanogobius lasti were available for this study (specimens AMS I.28968); they differ from the sagittae of Yarigobius gen. nov. and the other new genera due to their squarish shape, a flat outer face and a comparatively small sulcus. Thus, both the elevated number of abdominal vertebrae and the sagitta morphology confirm that Tasmanogobius is distinct from the studied fossils.

iv. Gobionellus has the autapomorphy of a "blunt, distally flared fourth neural spine" (Pezold 2004), which is clearly not present in Yarigobius gen. nov. or any of the other new fossil genera. Moreover, based on the sagittae of Gobionellus oceanicus (Pallas 1770) and G. stomatus Starks 1913 shown in Gomes Barboza (2019: fig. 4), the genus Gobionellus is characterized by a rectangular sagitta that is distinctively higher than long and has a small posterodorsal projection. This type of sagitta is very different from the sagittae of Yarigobius gen. nov. and the other new genera, which is consistent with the assumption that Gobionellus is not closely related to the studied fossils.

To conclude, based on the evidence derived from their skeletal characters, $†$ Katyagobius gen. nov., $†$ Pseudolesueurigobius gen. nov., $\uparrow$ Sarmatigobius gen. nov. and $\uparrow$ Yarigobius gen. nov. are assigned here to the family Gobiidae. Their sagittae neither support nor contradict such an assignment, as similar sagittae are unknown in both the Gobiidae and Oxudercidae. But, as otolith data on the numerous species of the Gobiidae is still limited, future work may possibly reveal gobiids with sagittae similar to those described here.

\section{Possible assignment to a gobiid lineage?}

The Gobiidae can be divided into 14 lineages based on molecular data (Agorreta et al. 2013; Thacker 2015). The assignment of the new fossil species to one of these gobiid lineages would require a phylogenetic matrix based on morphology comprising members of all lineages, which is currently not available. Hence, the following considerations are based on literature data (see Table 2), the comparative material (Appendix Table, Supplementary Data 2), and the best-fit approach sensu Penk et al. (2019). The aim is to determine to which of the extant gobiid lineages the new fossil genera are most likely to be related based on the numbers of shared characters.

We compiled the vertebral counts for all lineages based on (i) the available information for a gobiid genus (see Table 2), and (ii) by sorting each genus to its lineage according to the molecular phylogenies presented by Agorreta et al. (2013) and Thacker (2015). The outcome reveals that, on the whole, the vertebral counts are rather constant within lineages (Table 2). The most common count is $10+16$, which occurs in nine lineages, with little variation (Table 2). This count can be interpreted as a plesiomorphic condition among the Gobiidae, because it is shared with the Thalasseleotrididae, to which the Gobiidae + Oxudercidae are sister (Gill and Mooi 2012; Thacker et al. 2015). Correspondingly, the vertebral counts of the new genera $(10+17-19)$ represent a derived character state and can be used to infer their possible phylogenetic relationships.

Most members of the European Gobius lineage, as well as many species of the New World Gobiidae, have 11 abdominal vertebrae (Birdsong et al. 1988; Miller 2004; Hoese 
and Larson 2005). Ten abdominal vertebrae-as in our fossils-are present in many Indo-Pacific as well as in some European gobiids (Birdsong et al. 1988; Hoese and Larson 2005; Table 2). However, a vertebral count of $10+17-18$, as in the fossils described here, seems to be restricted to the Indo-Pacific Glossogobius lineage and to two European lineages (Gobius and Aphia) (Miller 1986; Birdsong et al. 1988; Goren 1996). Furthermore, a count of $10+19$ (as in $\dagger$ Yarigobius decoratus gen. et sp. nov.) is only known for a single species of the tadpole goby Benthophilus (Gobius lineage), namely Benthophilus leobergius Iljin in Berg, 1949 (see Ahnelt 2003, as B. stellatus leobergi). Usually, a number of nine abdominal vertebrae is diagnostic for Benthophilus (Miller 2004). In any case, a relationship between Benthophilus and $\dagger$ Yarigobius gen. nov. can be excluded because Benthophilus is characterized by several derived characters including, amongst others, its tad-pole like body (not present in $†$ Yarigobius gen. nov.), the absence of scales (vs. present in $†$ Yarigobius gen. nov.) and a first dorsal fin with only 2-4 spines (vs. six spines) (see Vasil'eva 1983; Ahnelt 2003; Miller 2004; Boldyrev and Bogutskaya 2007).

We continued the search for the 'best fit' by considering which members of the Glossogobius, Gobius and Aphia lineages share with the newly described fossils a similarly large number of soft rays in the D2 (14-16) and the anal fin (13-15). On this basis, it is unlikely that the fossils are related to the Glossogobius lineage, because each of the four genera included in it (after Thacker 2015) has distinctively fewer soft rays in both the D2 and anal fin: In Bathygobius there are nine (D2) and eight (anal fin) (Miller and Stefanni 2001; Tornabene et al. 2010); in Glossogobius 11 (D2) and up to nine (anal fin) (Hoese and Allen 2009; Hoese et al. 2015); in Grallenia the maxima are 10 (D2) and nine (anal fin) (Shibukawa and Iwata 2007), and in Psammogobius the numbers are up to 10 (D2) and up to 11 (anal fin) (Maugé 1986; Froese and Pauly 2021). A similar result is obtained for the genera of the Gobius lineage that share the vertebral count of $10+17$ with the fossils. Their numbers of soft rays in the anal fin are consistently lower than in the fossils: in Caffrogobius the number is 8-12 (Goren 1996); in Coryogalops it is 8-11 (Kovačić et al. 2014); in Gorogobius it is 9-11 (Kovačić and Schliewen 2008); in Hetereleotris it is up to 11 (Hoese 1986a; Hoese and Larson 2005; Kovačić et al. 2014); and in Sufflogobius it is 12-13 (Hoese 1986b). However, the two genera comprising the Aphia lineage, Lesueurigobius and Aphia, share high counts of soft rays in the D2 and anal fin with the fossils (Miller 1986; La Mesa et al. 2005). But, as mentioned above, the sagittae of Lesueurigobius are almost rectangular, have a dorsal portion that is equal or slightly wider than the ventral portion, and a broad posterodorsal region (in $L$. friesii) or projection (in $L$. suerii) (Fig. 12; see also Nolf 2013: pl. 324; Lombarte et al. 2018: fig. 2b, c; Schwarzhans et al. 2020b: pl. 2, figs. 1-3); they are thus very different from the sagittae of the fossils. Conversely, the lapillus of Lesueurigobius, shown here in Fig. 10i-j, has a similar shape (in ventral view) to that of $\dagger$ Pseudolesueurigobius gen. nov., and its lateral view somewhat resembles the lateral view of the lapillus of $\uparrow$ Yarigobius decoratus gen. et sp. nov. But also the lateral view of the lapillus of the extant Gobius, shown here in Fig. 4c, d and Fig. 10h, is superficially similar to that of $\dagger Y$. decoratus gen. et sp. nov. One should keep in mind that almost nothing is known concerning the diagnostic characters of gobiid lapilli; thus the observed similarities should be treated with caution. The sagitta of Aphia minuta shows a rounded ventral margin (La Mesa 1999), which makes it somewhat similar to the sagittae of the fossils. However, A. minuta is characterized by the persistence of several larval traits in adulthood ( $\mathrm{La}$ Mesa et al. 2005). It is possible that its sagitta shape is one of these, because a rounded sagitta is typical for larval and very juvenile teleosts (Nolf 1985; Vahed et al. 2018, 2019). The lapillus of A. minuta is illustrated in Assis (2000). Its lateral view is similar to that of the lapillus of $†$ Katyagobius gen. nov., but, as stated above, the database concerning gobiid lapilli is too limited for a secure conclusion to be drawn.

In conclusion, the fossil gobiids reported here were probably not members of the Aphia lineage, but can be interpreted as a stem lineage of this clade. This would be consistent with the fossil record, because the Aphia lineage appears to be an ancient clade. The oldest otoliths similar to those of Lesueurigobius were reported from the marine upper Oligocene Eger Formation (27.3-23.04 Ma) of the Central Paratethys (Nolf and Brzobohatý 1994, as "genus aff. Lesueurigobius" sp.).

\section{The fossil record of Lesueurigobius}

There is a rich otolith-based fossil record of Lesueurigobius, but no skeleton-based fossil has yet been recovered. In the early Miocene (early Aquitanian, c. 23-22 Ma), Lesueurigobius was abundantly present in the western Mediterranean Sea, where it comprised up to $90 \%$ of the ancient gobiid assemblage (Reichenbacher and Cappetta 1999). Until the end of the early Miocene (Karpatian), the only recognized species of the genus is $\dagger L$. vicinalis (Koken 1891) (Reichenbacher 1998; Schultz 2013). In the middle Miocene (Badenian) of the Central Paratethys, three species occur, i.e., $\dagger L$. bicornutus (Lin et al., 2015), $† L$. magnijugis Schwarzhans, 2017 and $\dagger L$. vicinalis (Koken, 1891) (Schultz 2013; Schwarzhans et al. 2020b). Given the substantial variability of the otoliths identified as $\dagger L$. vicinalis, and considering that the otoliths of the extant $L$. friesii and $L$. suerii species are virtually indistinguishable from each other (Fig. 12), the otoliths of $\dagger L$. vicinalis may actually represent several species. Likewise, fossil otoliths identified as $L$. aff. vicinalis, or resembling Lesueurigobius but left in open nomenclature 
(e.g., Steurbaut 1984; Radwańska 1992; Brzobohatý 1994; Brzobohatý et al. 2007; Caputo et al. 2009), could indicate a hidden diversity of the genus Lesueurigobius during the Miocene.

\section{Concluding remarks}

The present study is the first part of a project on the fossil gobioid fishes from the lower Volhynian (lower Sarmatian s.1.) strata exposed at Karpov Yar, Naslavcea, northern Moldova, which formed part of the western region of the Eastern Paratethys at that time. We focused exclusively on those fossil specimens that resembled the extant genus Lesueurigobius Whitley, 1950 in possessing a longish or lanceolate caudal fin and large numbers of soft rays in the D2 and anal fin. In most of these specimens, the otoliths were preserved in situ. There are several additional gobiid species from Karpov Yar which are unrelated to the specimens studied here; they will be documented in subsequent reports. Here, four new genera comprising six species, of which five are new, are described. As all species share a unique combination of characters, they are interpreted as a monophyletic group. Their skeleton data imply a close relationship with Lesueurigobius, but the otoliths preserved in situ do not support such a classification. A number of six species of Lesueurigobius look-alikes from a single site seems surprisingly high at first sight. However, the fossil record of otoliths attributed to Lesueurigobius by previous authors also suggests that the true Lesueurigobius may have been much more diverse in the Miocene than is currently recognized.

Among the new fossil species described in this study, only $†$ Sarmatigobius iugosus comb. nov. has previously been reported, based on three isolated otoliths from marine and lagoonal deposits of the Badenian and upper Badenian-lower Sarmatian of the Central Paratethys (Schwarzhans et al. 2020b, as †Hesperichthys iugosus). The presence of a gobiid species in the lower Volhynian of northern Moldova that was previously known only from the Central Paratethys could argue in favour of a marine or euryhaline gateway between the Central and Eastern Paratethys, as proposed by Popov et al. (2004). However, the sparse finds of $\dagger S$. iugosus otoliths in the marine Badenian, which is generally rich in gobiid otoliths, imply that it was a rare species. Hence, it could be argued that $\uparrow S$. iugosus has not previously been found in the time-equivalent (Konkian) otolith assemblages of the Eastern Paratethys (see Bratishko et al. 2015) because it was rare; thus we cannot be sure that it was restricted to the Central Paratethys.

The discovery of four new gobiid genera that most likely formed a monophyletic group in the lower Volhynian of northern Moldova indicates that the overall character of European gobiid diversity about $12 \mathrm{Ma}$ was clearly different from that seen today. On the basis of the best-fit approach sensu Penk et al. (2019), the new fossils were classified as a possible stem lineage of the European Aphia lineage, which is represented today by $A$. minuta and five species of Lesueurigobius. Given the long stratigraphic range of Lesueurigobius, for which otoliths are known from as far back as the late Oligocene, the presence of a stem lineage of its clade (the Aphia lineage) is not unexpected. It also implies that the phenotype of Lesueurigobius, and its 'lookalikes', was successful over the long evolutionary history of the Gobiidae, although few of the extant gobiid species have retained the large numbers of rays in the D2 and anal fin that are - together with other traits-characteristic for the group.

\section{Appendix Table: Morphological characters of Lesueurigobius friesii (Malm, 1874) and Lesueurigobius sanzi (de Buen, 1918)}

\begin{tabular}{|c|c|c|c|}
\hline & $\begin{array}{l}\text { L. friesii ( } 7 \text { specimens, NMP6V } \\
\text { 146223-146225, 146227- } \\
\text { 146230) }\end{array}$ & $\begin{array}{l}\text { L. sanzi (2 specimens, ZSM } \\
\text { 035529_1,_4) }\end{array}$ & Combined \\
\hline SL (mm) & $44.8-50.3$; up to $100^{\mathrm{Mi}}$ & $61.2-64.1$; at least $95^{\mathrm{Mi}}$ & \\
\hline \multicolumn{4}{|c|}{ Morphometry in \% of SL (see Suppl. Data 2 for raw measurements) } \\
\hline Head length & $21.8-24.2(22.9 \pm 0.7)$ & $\begin{array}{l}22.9-25.5(24.2 \pm 1.8)^{(\mathrm{Bu})} \\
26-28^{\mathrm{Ol}}, \text { in juv. } 30^{\mathrm{Ol}}\end{array}$ & $21.8-25.5(23.2 \pm 1.1)$ \\
\hline Lower jaw & $11.1-12.6(11.9 \pm 0.6)$ & $13.1-13.6(13.3 \pm 0.3)$ & $11.1-13.6(12.2 \pm 0.8)$ \\
\hline Predorsal distance to $\mathrm{D} 1$ & $32.2-34.2(33.5 \pm 0.7)$ & $31.7-33.8(32.7 \pm 1.5)$ & $31.7-34.2(33.3 \pm 0.9)$ \\
\hline Predorsal distance to $\mathrm{D} 2$ & $51.1-53.3(52.5 \pm 0.8)$ & $53.5-54.6(54.0 \pm 0.8)$ & $51.1-54.6(52.8 \pm 1.0)$ \\
\hline $\begin{array}{l}\text { Distance end of D2 to first } \\
\text { procurrent caudal ray }\end{array}$ & $11.7-14.2(12.8 \pm 1.0)$ & $9.0-10.6(9.8 \pm 1.1)$ & $9.0-14.2(12.1 \pm 1.6)$ \\
\hline Prenanal distance & $56.9-59.9\{57.7 \pm 0.8)$ & $57.4-58.2(57.8 \pm 0.5)$ & $56.9-59.0(57.7 \pm 0.7)$ \\
\hline Caudal peduncle length & $18-20.1(19.0 \pm 0.8)$ & $13.4-14.2(13.8 \pm 0.6)$ & $13.4-20.1(17.9 \pm 2.4)$ \\
\hline
\end{tabular}




\begin{tabular}{|c|c|c|c|}
\hline & $\begin{array}{l}\text { L. friesii ( } 7 \text { specimens, NMP6V } \\
\text { 146223-146225, 146227- } \\
\text { 146230) }\end{array}$ & $\begin{array}{l}\text { L. sanzi (2 specimens, ZSM } \\
\left.035529 \_1, \_4\right)\end{array}$ & Combined \\
\hline $\begin{array}{l}\text { Minimum caudal peduncle } \\
\text { depth }\end{array}$ & $7.7-8.9(8.4 \pm 0.4)$ & $9.2-9.8(9.5 \pm 0.4)$ & $7.7-9.8(8.6 \pm 0.6)$ \\
\hline $\mathrm{BD}$ at origin of $\mathrm{D} 1$ & $17.1-20.0(18.3 \pm 1.1)$ & $22.2-23.4(22.8 \pm 0.8)$ & $17.1-23.4(19.3 \pm 2.2)$ \\
\hline $\mathrm{BD}$ at origin of $\mathrm{A}$ & $14.2-16.1(15.3 \pm 0.7)$ & $19.8-20.0(19.9 \pm 0.1)$ & $14.2-20.0(16.3 \pm 2.1)$ \\
\hline D1 base & $10.9-12.6(11.6 \pm 0.6)$ & $12.9(12.9 \pm 0)$ & $10.9-12.9(11.9 \pm 0.8)$ \\
\hline D2 base & $29.0-32.3(30.7 \pm 1.1)$ & $31.2-31.7(31.5 \pm 0.4)$ & $29.0-32.3(30.9 \pm 1.0)$ \\
\hline $\begin{array}{l}\text { Distance between insertion of } \\
\text { D1-spine VI and begin of D2 }\end{array}$ & $6.7-8.6(7.6 \pm 0.8)$ & $7.8-9.0(8.4 \pm 0.9)$ & $6.7-9.0(7.8 \pm 0.8)$ \\
\hline $\begin{array}{l}\text { Distance between insertion of } \\
\text { D1-spines V and VI }\end{array}$ & $3.4-4.2(3.8 \pm 0.3)$ & $4.7-4.9(4.8 \pm 0.2)$ & $3.4-4.9(4.0 \pm 0.5)$ \\
\hline $\begin{array}{l}\text { Distance between insertion of } \\
\text { D1-spines IV and V }\end{array}$ & $2.1-2.4(2.2 \pm 0.1)$ & $2.0-2.5(2.2 \pm 0.3)$ & $2.0-2.5(2.2 \pm 0.2)$ \\
\hline $\begin{array}{l}\text { Ratio of distance D1-spines V- } \\
\text { VI / IV-V }\end{array}$ & $1.6-1.9(1.7 \pm 0.1)$ & $2.0-2.3(2.2 \pm 0.2)$ & $1.6-2.3(1.8 \pm 0.2)$ \\
\hline D2 spine length & $8.3-9.3(8.8 \pm 0.5)$ & $8.5-9.2(8.9 \pm 0.5)$ & $8.3-9.3(8.8 \pm 0.4)$ \\
\hline A base & $23.7-24.3(24.0 \pm 0.3)$ & $28.7-29.4(29.1 \pm 0.5)$ & $23.7-29.4(25.3 \pm 2.4)$ \\
\hline A spine length & $4.2-6.0(5.0 \pm 0.9)$ & 5.2 (single measurement) & $4.2-6.0(5.0 \pm 0.7)$ \\
\hline A spine length in $\%$ of next ray & $68.0-80.0(74.7 \pm 6.1)$ & - & as for $L$. friesii \\
\hline Caudal fin length & $25.8-30.3(27.1 \pm 2.1)$ & $23.5-27.1(25.3 \pm 2.6)$ & $23.5-30.3(26.5 \pm 2.2)$ \\
\hline Pectoral fin length & $16.2-20.5(18.9 \pm 1.8)$ & $18.8-20.9(19.8 \pm 1.5)$ & $16.2-20.9(19.2 \pm 1.7)$ \\
\hline Pelvic fin length & $18.3-21.6(19.6 \pm 1.3)$ & $22.2-22.8(22.5 \pm 0.4)$ & $18.3-22.8(20.3 \pm 1.7)$ \\
\hline Pelvic fin spine length & $5.0-5.5(5.2 \pm 0.2)$ & - & as for $L$. friesii \\
\hline $\begin{array}{l}\text { Pelvic fin spine length (\% of } \\
\text { next ray) }\end{array}$ & $83.0-92.6(89.3 \pm 5.5)$ & - & as for $L$. friesii \\
\hline Abd. vertebral column length & $28.6-29.5(29.0 \pm 0.4)$ & $27.1-28.1(27.6 \pm 0.7)$ & $27.1-29.5(28.7 \pm 0.8)$ \\
\hline Caudal vertebral column length & $47.4-49.2(48.5 \pm 0.7)$ & $48.9-49.5(49.2 \pm 0.4)$ & $47.4-49.5(48.7 \pm 0.7)$ \\
\hline $\begin{array}{l}\text { Abd. vertebral column in } \% \text { of } \\
\text { caudal vertebral column }\end{array}$ & $58.4-61.9(59.9 \pm 1.3)$ & $55.5-56.8(56.2 \pm 0.9)$ & $55.5-61.9(59.0 \pm 2.0)$ \\
\hline \multicolumn{4}{|c|}{ Meristics (see Suppl. Data 2 for individual data) } \\
\hline Vertebrae (abd. + caudal) & $27(10+17)$ & $27(10+17)$ & $27(10+17)$ \\
\hline D1 spines & VI & $\mathrm{VI}+$ long filaments & VI \\
\hline D1 pterygiophore formula & $3-22110$ & $3-22110$ & $3-22110$ \\
\hline D2 elements & $\begin{array}{l}\text { I14, I with filament } \\
\text { I14-16 }\end{array}$ & $\mathrm{I} 15-16^{(\mathrm{Bu})}$ & $14-16(14.3 \pm 0.7)$ \\
\hline A elements & $\begin{array}{l}\mathrm{I} 13, \mathrm{I} 12-15^{\mathrm{Ma}, \mathrm{Mi}} \\
\mathrm{I} 13-15^{\mathrm{Bu}}\end{array}$ & $\begin{array}{l}\mathrm{I} 16, \mathrm{I} 16-17^{\mathrm{Ma}, \mathrm{Mi}} \\
\mathrm{I} 16-18^{\mathrm{Bu}}\end{array}$ & $13-16(13.8 \pm 1.4)$ \\
\hline $\mathrm{AP}$ & 2 & 2 & 2 \\
\hline $\begin{array}{l}\text { Caudal fin rays, segmented } \\
\text { (dorsal/ventral) }\end{array}$ & $15(8 / 7)$ & $16(8 / 8)$ & $15-16(8 / 7-8)$ \\
\hline $\begin{array}{l}\text { Caudal procurrent rays (dorsal/ } \\
\text { ventral) }\end{array}$ & $8-9 / 8-9$ & $9-11 / 7-10$ & $8-11 / 7-9$ \\
\hline Pectoral fin rays & $18-19^{(\mathrm{Bu}, \mathrm{Ma}, \mathrm{Mi})}$ & $22^{(\mathrm{Bu}, \mathrm{Ma}, \mathrm{Mi})}$ & $18-22(19.1 \pm 1.3)$ \\
\hline Pelvic fin elements & $\mathrm{I}, 5$ & $\mathrm{I}, 5$ & $\mathrm{I}, 5$ \\
\hline \multicolumn{4}{|c|}{ Other fin related characters (see Suppl. Data 2 for individual data) } \\
\hline D2 spine shape & slightly curved or curved & very slightly curved & slightly curved or curved \\
\hline A spine shape & straight or curved & curved & straight or curved \\
\hline $\begin{array}{l}\text { Insertion of } \mathrm{A} \text { in relation to } \mathrm{D} 2 \\
\text { origin }\end{array}$ & $1.5-2$ vertebrae behind & 1.5 vertebrae behind & $1.5-2$ vertebrae behind \\
\hline $\begin{array}{l}\text { last } \mathrm{D} 2 \text { rays reach procurrent } \\
\text { rays }\end{array}$ & variable, mostly yes & yes & variable, mostly yes \\
\hline
\end{tabular}




\begin{tabular}{llll}
\hline & $\begin{array}{l}\text { L. friesii (7 specimens, NMP6V } \\
\text { 146223-146225, 146227- } \\
146230)\end{array}$ & $\begin{array}{l}\text { L. sanzi (2 specimens, ZSM } \\
\text { 035529__,_4) }\end{array}$ & Combined \\
\hline $\begin{array}{l}\text { last A rays reach procurrent } \\
\text { rays }\end{array}$ & no & yes & no or yes \\
$\begin{array}{l}\text { Caudal fin shape } \\
\text { Squamation }\end{array}$ & lanceolate & lanceolate & lanceolate \\
$\begin{array}{l}\text { Flank scales } \\
\text { Scales in longitudinal row }\end{array}$ & ctenoid & & ctenoid \\
Predorsal scales & $28-29^{\mathrm{Bu}, \mathrm{Mi}}$ & ctenoid & $25-28$ \\
\hline
\end{tabular}

Values indicate ranges; mean values \pm standard deviation are given in brackets; morphometric values refer to $\%$ of standard lengths. Superscripts indicate the literature source, superscripts in brackets refer to literature data consistent with our new data (Bu, de Buen 1931; Mi, Miller 1986; Ma, Maul 1971; Ol, Olivar 1989). Other abbreviations: A, anal fin; abd., abdominal; AP, number of pterygiophores of anal fin inserting before the first caudal vertebra; BD, body depth; D1, first dorsal fin; D2, second dorsal fin; juv., juveniles; -, could not be determined. For individual measurements and counts of the specimens, see Supplementary Data 2.

\section{Supplementary information}

Supplementary Data 1 Raw data of measurements (mm) of the new gobiid fossils from Karpov Yar, Naslavcea, northern Moldova.

Supplementary Data 2 Individual measurements (in $\mathrm{mm}$ ) and counts of the studied specimens of Lesueurigobius friesii (Malm, 1874) and Lesueurigobius sanzi (de Buen, 1918).

Supplementary data $3 \dagger$ Katyagobius sp. from Karpov Yar, Naslavcea, northern Moldova.

Acknowledgements We thank Radek Šanda (National Museum Praha, Czech Republic), Jasna Vukić (Charles University, Praha, Czech Republic), Ulrich Schliewen (SNSB-Bavarian State Collection of Zoology, Munich, Germany) and Moritz Sonnewald (Senckenberg Forschungsinstitut und Naturmuseum, Frankfurt, Germany) for access to extant comparative material of the genus Lesueurigobius. We acknowledge Dirk Nolf and Kristiaan Hoedemakers (both Royal Institute of Natural Sciences Belgium, Brussels) for providing the SEM images of Lesueurigobius friesii and L. suerii otoliths used here in Figure 12 from the collection in their care. We thank Kerryn Parkinson and Amanda Hay (both Australian Museum, Sydney, Australia) as well as Werner Schwarzhans (Hamburg, Germany) for providing access to X-rays and otoliths of Tasmanogobius lasti. The photographs of Fig. 5b-d, f and of the Supplementary Data 3 are courtesy of Mr. Sergey V. Bagirov (PIN, Moscow, Russia), and the photograph of Fig. 5e is courtesy of Mrs. Manuela Schellenberger (SNSB-Bavarian State Collection of Palaeontology and Geology). We are grateful to Ulrich Schliewen for constructive comments on character distribution and variability in gobies, and for providing literature. We also thank Ronald Fricke (Stuttgart, Germany) and Helen Larson (Darwin, Australia) for helping with literature that was difficult to find, and Mathias Harzhauser and Oleg Mandic (both Natural History Museum, Vienna, Austria) for their help with the actual taxonomic names of the molluscs from the lower Volhynian of Karpov Yar. Finally, we thank Paul Hardy (Düsseldorf, Germany) for critical reading of the manuscript, the two reviewers for their constructive comments, and the chief editor of PalZ, Mike Reich (SNSB-Bavarian State Collection of Palaeontology and Geology, Munich, Germany), for helpful advice.

Funding Open Access funding enabled and organized by Projekt DEAL.

Open Access This article is licensed under a Creative Commons Attribution 4.0 International License, which permits use, sharing, adaptation, distribution and reproduction in any medium or format, as long as you give appropriate credit to the original author(s) and the source, provide a link to the Creative Commons licence, and indicate if changes were made. The images or other third party material in this article are included in the article's Creative Commons licence, unless indicated otherwise in a credit line to the material. If material is not included in the article's Creative Commons licence and your intended use is not permitted by statutory regulation or exceeds the permitted use, you will need to obtain permission directly from the copyright holder. To view a copy of this licence, visit http://creativecommons.org/licenses/by/4.0/.

\section{References}

Agiadi, K., E. Koskeridou, M. Triantaphyllou, A. Girone, and V. Karakitsios. 2013. Fish otoliths from the Pliocene Heraklion Basin (Crete Island, Eastern Mediterranean). Geobios 46(6): 461-472. https://doi.org/10.1016/j.geobios.2013.07.004.

Agiadi, K., G. Vasileiou, E. Koskeridou, P. Moisette, and J.-J. Cornée. 2019. Coastal fish otoliths from the early Pleistocene of Rhodes (eastern Mediterranean). Geobios 55: 1-15. https://doi.org/10. 1016/j.geobios.2019.06.006.

Agorreta, A., D. San Mauro, U. Schliewen, J.L. van Tassell, M. Kovačić, R. Zardoya, and L. Rüber. 2013. Molecular phylogenetics of Gobioidei and phylogenetic placement of European gobies. Molecular Phylogenetics and Evolution 69(3): 619-633. https:// doi.org/10.1016/j.ympev.2013.07.017.

Ahnelt, H. 2003. The postcranial skeleton of the benthophiline gobiids Anatirostrum and Benthophilus (Teleostei: Gobiidae). Folia Zoologica 52(2): 213-221.

Ahnelt, H., and M. Duchkowitsch. 2004. The postcranial skeleton of Proterorhinus marmoratus with remarks on the relationships of the genus Proterorhinus (Teleostei: Gobiidae). Journal of 
Natural History 38(7): 913-924. https://doi.org/10.1080/00222 93021000047873.

Akihito, A., T. Iwata, K. Kobayashi, T. Ikeo, H. Imanishi, Y. Umehara. Ono, et al. 2000. Evolutionary aspects of gobioid fishes based upon a phylogenetic analysis of mitochondrial cytochrome $b$ genes. Gene 259(1-2): 5-15. https://doi.org/10.1016/S03781119(00)00488-1.

Arambourg, C. 1927. Les poissons fossiles d'Oran. Matériaux pour la Carte géologique d'Algerie (1re Serie: Paleontologie) 6: 1-291.

Arratia, G. 1999. The monophyly of Teleostei and stem-group teleosts. Consensus and disagreements. In Mesozoic Fishes 2 - Systematics and Fossil Record, eds. G. Arratia, and H-P. Schultze, 265334. München: F. Pfeil

Assis, C.A. 2000. Estudo morfológico dos otólitos Sagitta, Asteriscus e Lapillus de teleósteos (Actinopterygii, teleostei) de Portugal Continental. Dissertation, Universidade de Lisboa, Lisboa

Assis, C.A. 2005. The utricular otoliths, lapilli, of teleosts: their morphology and relevance for species identification and systematics studies. Scientia Marina 69(2): 259-273.

Bachmayer, F. 1980. Eine fossile Schlangennadel (Syngnathidae) aus dem Leithakalk (Badenien) von St. Margarethen, Burgenland (Österreich). Annalen des Naturhistorischen Museums in Wien 83: 29-33.

Bannikov, A.F. 1986. The first discovery of fossil wrasses (Teleostei) in the Sarmatian Deposits of Moldavia. Paleontological Journal 20(1): 57-62.

Bannikov, A.F. 1989a. The first discovery of scale-bearing blennies (Teleostei) in the Sarmatian of Moldavia. Paleontological Journal 23(2): 59-65.

Bannikov, A.F. 1989b. Neogene dactylopterans (Teleostei, Polynemidae) of the USSR. Paleontological Journal 23(4): 124-129.

Bannikov, A.F. 1990. A new smarid fish (Perciformes, Centracanthidae) from the Sarmatian of Moldavia. Paleontological Journal 24(2): 99-103.

Bannikov, A.F. 1992. The discovery of centropomid fishes (Perciformes) in the Lower Sarmatian of Moldova. Paleontological Journal 26(3): 83-91.

Bannikov, A.F. 1993. A new species of bass (Teleostei, Moronidae) from the Sarmatian of Moldova. Paleontological Journal 27(1): $54-62$.

Bannikov, A.F. 1998. New blennioid fishes of the families Blenniidae and Clinidae (Perciformes) from the Miocene of the Caucasus and Moldova. Paleontological Journal 32(4): 385-389.

Bannikov, A.F. 2006. On the Miocene Centracanthidae (Teleostei, Perciformes) from the Eastern Paratethys. Paleontological Journal 40(1): 100-102. https://doi.org/10.1134/s0031030106010114.

Bannikov, A.F. 2009. On early Sarmatian fishes from the Eastern Paratethys. Paleontological Journal 43(5): 569-573. https://doi.org/ 10.1134/s003103010905013x.

Bannikov, A.F. 2010. Fossil vertebrates of Russia and adjacent countries. Fossil acanthopterygians fishes (Teleostei, Acanthopterygii). Moscow: GEOS

Bannikov, A.F. 2017. New data on the distribution of the fossil gobiiform fishes in the Miocene of the Eastern Paratethys. In The 10th Indo-Pacific Fish Conference, Tahiti 2-6 October 2017, p. 138.

Bannikov, A.F. 2018. New data on the distribution of the gobiiform fishes (Gobioidei) in the Eastern Paratethys [Novye dannye o rasprostranenii bychkovidnykh ryb (Gobioidei) v Vostochnom Paratetise]. In Basic and Applied Paleontology. Materials of LXIV session of the Paleontological Society, 175-176. St. Petersburg: VSEGEI

Bannikov, A.F. 2019. Early Sarmatian (Volhynian) bony fishes of the Eastern Paratethys [Rannesarmatskiye (volynskiye) kostistye ryby Vostochnogo Paratetisa]. In Morphological Evolution and Stratigraphic Problems. Materials of LXIV session of the Paleontological Society, 207-209. St. Petersburg: VSEGEI.
Bannikov, A.F., and G. Carnevale. 2016. $†$ Carlomonnius quasigobius gen. et sp. nov.: the first gobioid fish from the Eocene of Monte Bolca, Italy. Bulletin of Geosciences 91(1): 13-22. https://doi. org/10.3140/bull.geosci.1577.

Bannikov, A.F., G. Carnevale, and A.N. Kotlyar. 2016. A new halfbeak species (Beloniformes, Hemiramphidae) from the Lower Sarmatian of the Krasnodar Region. Paleontological Journal 50(6): 616-622.

Baykina, E.M. 2013. A revision of Clupea doljeana Kramberger and Sarmatella vukotinovici (Kramberger) (Pisces, Clupeidae) from the Sarmatian of Croatia. Paleontological Journal 47(5): 523-532.

Baykina, E.M., and W.W. Schwarzhans. 2017. Review of "Clupea humilis" from the Sarmatian of Moldova and description of Moldavichthys switshenskae gen. et sp. nov. Swiss Journal of Palaeontology 136(1): 141-149. https://doi.org/10.1007/ s13358-016-0121-6.

Berg, L.S. 1949. Freshwater Fishes of the USSR and Adjacent Countries, 4th ed., vol. 3, 927-1382. Moscow: Izdatel'stvo Akademii Nauk SSSR.

Betancur-R, R., E.O. Wiley, G. Arratia, A. Acero, N. Bailly, M. Miya, G. Lecointre, and G. Ortí. 2017. Phylogenetic classification of bony fishes. BMC Evolutionary Biology 17(162): 1-40. https:// doi.org/10.1186/s12862-017-0958-3.

Birdsong, R.S., E.O. Murdy, and F.L. Pezold. 1988. A study of the vertebral column and median fin osteology in gobioid fishes with comments on gobioid relationships. Bulletin of Marine Science 42(2): 174-214.

Bogatshev, V.V. 1955. Amvrosievskiye nizhnesarmatskiye ryby. Doklady Akademii Nauk SSSR 105: 570-572.

Boldyrev, V.S., and N.G. Bogutskaya. 2007. Revision of the tadpolegobies of the genus Benthophilus (Teleostei: Gobiidae). Ichthyological Exploration of Freshwaters 18(1): 31-96.

Boltachev, A.R., and E.P. Karpova. 2010. Naturalization of the Pacific Chameleon Goby Tridentiger trigonocephalus (Perciformes, Gobiidae) in the Black Sea (Crimea, Sevastopol Gulf). Journal of Ichthyology 50(2): 188-196.

Bradić-Milinović, K., H. Ahnelt, L. Rundić, and W. Schwarzhans. 2019. The lost freshwater goby fish fauna (Teleostei, Gobiidae) from the early Miocene of Klinci (Serbia). Swiss Journal of Palaeontology 138(2): 285-315. https://doi.org/10.1007/ s13358-019-00194-4.

Bratishko, A., W. Schwarzhans, B. Reichenbacher, Y. Vernyhorova, and S. Ćorić. 2015. Fish otoliths from the Konkian (Miocene, early Serravallian) of Mangyshlak (Kazakhstan): Testimony to an early endemic evolution in the Eastern Paratethys. Paläontologische Zeitschrift 89(4): 839-889. https://doi.org/10.1007/ s12542-015-0274-4.

Brzobohatý, R. 1994. Die Fischotolithen des Badenien von Gainfarn, Niederösterreich (Mittelmiozän, Wiener Becken). Annalen des Naturhistorischen Museums in Wien (A: Mineralogie und Petrographie, Geologie und Paläontologie, Archäozoologie, Anthropologie und Prähistorie) 96: 67-93.

Brzobohatý, R., and J. Stancu. 1974. Die Fischfauna des Sarmatien s. str. In Chronostratigraphie und Neostratotypen, Miozän der zentralen Paratethys, eds. Papp, A., Marinescu, F. and Seneš, J. 492-515. Bratislava: Veda.

Brzobohatý, R., D. Nolf, and O. Kroupa. 2007. Fish otoliths from the Middle Miocene of Kienberg at Mikulov, Czech Republic, Vienna Basin: their paleoenvironmental and paleogeographic significance. Bulletin de l'institut Royal des Sciences Naturelles de Belgique, Sciences de la Terre 77: 167-196.

Buen, F. de. 1918. Los Góbidos de la Península Ibérica y Baleares. Nota II. Catálogo sistemático y ensayo de distríbución geográfica. Boletin de Pescas 26: 291-337. 
Buen, F. de. 1931. Notas a la familia Gobiidae. Observaciones sobre algunos géneros y sinopsis de las especies ibéricas. Notas y Resúmenes, Instituto Español de Oceanografia 1931: 1-76.

Caputo, D., G. Carnevale, and W. Landini. 2009. Fish otoliths from the Messinian of Strada degli Archi (Tuscany, Italy) — Taxonomy and palaeoecology. Annalen des Naturhistorischen Museums in Wien (A: Mineralogie und Petrographie, Geologie und Paläontologie, Archäozoologie, Anthropologie und Prähistorie) 111: 257-280.

Carnevale, G., A.F. Bannikov, W. Landini, and C. Sorbini. 2006. Volhynian (early Sarmatian sensu lato) fishes from Tsurevsky, North Caucasus, Russia. Journal of Paleontology 80(4): 684-699. https://doi.org/10.1666/0022-3360(2006)80.

Carpenter, K.E., and N. De Angelis. 2016. The living marine resources of the Eastern Central Atlantic. Volume 4: Bony fishes part 2 (Perciformes to Tetradontiformes) and Sea turtles. In FAO Species Identification Guide for Fishery Purposes. Rome: Food and Agriculture Organization of the United Nations (FAO).

Carpenter, K.E., and V.H. Niem. 2001. The living marine resources of the Western Central Pacific. Volume 5. Bony fishes part 3 (Menidae to Pomacentridae). In FAO Species Identification Guide for Fishery Purposes. Rome: Food and Agriculture Organization of the United Nations (FAO).

Carpenter, K.E., F. Krupp, D.A. Jones, and U. Zajonz. 1997. The living marine resources of Kuwait, Eastern Saudi Arabia, Bahrain, Qatar, and the United Arab Emirates. In FAO Species Identification Field Guide for Fishery Purposes. Rome: Food and Agriculture Organization of the United Nations (FAO).

Cuvier, G. 1816. Le Règne Animal distribué d'après son organisation pour servir de base à l'histoire naturelle des animaux et d'introduction à l'anatomie comparée. Tome II, Les reptiles, les poissons, les mollusques et les annélides. Paris: A. Belin.

Defrance, J.L.M. 1823. Lucine (foss.). In Dictionnaire des Sciences Naturelles, Tome 27, ed. F.G. Levrault. Strasbourg, Paris: Le Normant.

Djafarova, J.D. 2006. Otolity neogena Azerbaidjana (Neogene otoliths of Azerbaijan). Baku: Nafta.

Eichwald, E. von. 1830. Naturhistorische Skizze von Lithauen, Volhynien und Podolien in geognostisch-mineralogischer, botanischer und zoologischer Hinsicht. Wilna: Voss.

Eichwald, E. von. 1853. Lethaea Rossica ou Paléontologie de la Russie. Troisième volume. Dernière période. Stuttgart: Schweizerbart.

Filipescu, S., A. Miclea, M. Gross, M. Harzhauser, K. Zágoršek, and C. Jipa. 2014. Early Sarmatian paleoenvironments in the easternmost Pannonian Basin (Borod Depression, Romania) revealed by the micropaleontological data. Geologica Carpathica 65(1): 67-81. https://doi.org/10.2478/geoca-2014-0005.

Froese, R., and D. Pauly. 2021. FishBase. World Wide Web electronic publication. www.fishbase.org, version (12/2020).

Gierl, C., and B. Reichenbacher. 2015. A new fossil genus of Gobiiformes from the Miocene characterized by a mosaic set of characters. Copeia 103(4): 792-805. https://doi.org/10.1643/ ci-14-146.

Gierl, C., and B. Reichenbacher. 2017. Revision of so-called Pomatoschistus (Gobiiformes Palaeontologia Electronica Teleostei) from the late Eocene and early Oligocene. Palaeontologia Electronica 20.2.33A: 1-17. https://doi.org/10.26879/721.

Gierl, C., B. Reichenbacher, J. Gaudant, D. Erpenbeck, and A. Pharisat. 2013. An extraordinary gobioid fish fossil from southern France. PLOS ONE 8(5): e64117. https://doi.org/10.1371/journal.pone. 0064117.

Gierl, C., D. Liebl, R. Šanda, J. Vukić, H.R. Esmaeili, and B. Reichenbacher. 2018. What can goby otolith morphology tell us? Cybium 42(4): 349-363. https://doi.org/10.26028/cybium/2018-424-006.

Gill, A.C., and R.D. Mooi. 2012. Thalasseleotrididae, new family of marine gobioid fishes from New Zealand and temperate Australia, with a revised definition of its sister taxon, the Gobiidae
(Teleostei: Acanthomorpha). Zootaxa 3266(1): 41-52. https:// doi.org/10.11646/zootaxa.3266.1.3.

Gomes Barboza, M. 2019. Índices de formas de otólitos de 10 espécies capturadas no litoral de Pernambuco (pe) e Paraíba (pb). Recife: Universidade Federal Rural de Pernambuco.

Goren, M. 1996. A review of the southern African gobiid fish genus Caffrogobius Smitt, 1900. The J.L.B Smith Institute of Ichthyology Special Publication 57: 1-28.

Gorjanovic-Kramberger, D. 1882. Die jungtertiäre Fischfauna Croatiens. Beiträge zur Paläontologie Österreich-Ungarns und des Orients 2(3): 86-135.

Günther, A.C.L.G. 1880. An Introduction to the Study of Fishes. Edinburgh: Adam and Charles Black.

Gut, C., J. Vukić, R. Šanda, T. Moritz, and B. Reichenbacher. 2020. Identification of past and present gobies: distinguishing Gobius and Pomatoschistus (Teleostei: Gobioidei) species using characters of otoliths, meristics and body morphometry. Contributions to Zoology 89: 282-323. https://doi.org/10.1163/18759866-bja10 002.

Harrison, I.J. 1989. Specialization of the gobioid palatopterygoquadrate complex and its relevance to gobioid systematics. Journal of Natural History 23(2): 325-353. https://doi.org/10.1080/00222 938900770211.

Harzhauser, M., and W.E. Piller. 2007. Benchmark data of a changing sea - Palaeogeography, palaeobiogeography and events in the Central Paratethys during the Miocene. Palaeogeography, Palaeoclimatology, Palaeoecology 253(1-2): 8-31. https://doi. org/10.1016/j.palaeo.2007.03.031.

Hinsbergh, V.W.M. van, and R.A. Helwerda. 2019. Fish Otoliths from the Cabarruyan Piacenzian-Gelasian fauna found in the Philippines. Zootaxa 4563(3): 401-443. https://doi.org/10.11646/zoota xa.4563.3.1.

Hoernes, M. 1856. Die fossilen Mollusken des Tertiaer-Beckens von Wien. Wien: K. K. Hof- und Staatsdruckerei.

Hoese, D.F. 1984. Gobioidei: relationships. In Ontogeny and systematics of fishes, eds. H.G. Moser, W.J. Richards, D.M. Cohen, M.P. Fahay, A.W. Kendall Jr., and S.L. Richardson, 588-591. Gainesville: American Society of Ichthyologists and Herpetologists.

Hoese, D.F. 1986a. Descriptions of two new species of Hetereleotris (Pisces: Gobiidae) from the western Indian Ocean, with discussion of related species. The J.L.B Smith Institute of Ichthyology Special Publication 41: 1-25.

Hoese, D.F. 1986b. Family No. 240: Gobiidae. In Smiths' Sea Fishes, eds. M.M. Smith and P.C. Heemstra, 774-807. Johannesburg: Macmillan South Africa.

Hoese, D.F. 1991. A revision of the temperate Australian gobiid (Gobioidei) fish genus Tasmanogobius with a comment on the genus Kimberleyeleotris. Memoirs of the Museum of Victoria 52(2): 361-376.

Hoese, D.F., and G.R. Allen. 2009. Description of three new species of Glossogobius from Australia and New Guinea. Zootaxa 1981: $1-14$.

Hoese, D.F., and A.C. Gill. 1993. Phylogenetic relationships of eleotridid fishes (Perciformes, Gobioidei). Bulletin of Marine Science 52(1): 415-440.

Hoese, D.F., and H.K. Larson. 2005. Description of two new species of Hetereleotris (Gobiidae) from the south Pacific, with a revised key to species and synonymization of the genus Pascua with Hetereleotris. Zootaxa 1096: 1-16.

Hoese, D.F., R.K. Hadiaty, and F. Herder. 2015. Review of the dwarf Glossogobius lacking head pores from the Malili lakes, Sulawesi, with a discussion of the definition of the genus. Raffles Bulletin of Zoology 63: 14-26.

Iglésias, S.P., J. Vukić, D.Y. Sellos, T. Soukupová, and R. Šanda. 2021. Gobius xoriguer, a new offshore Mediterranean goby (Gobiidae), and phylogenetic relationships within the genus Gobius. 
Ichthyological Research 68: 445-459. https://doi.org/10.1007/ s10228-020-00797-9.

Ionko, V.I. 1954. O nakhodke iskopayemykh ryb v nizhnesarmatskikh otlozheniyakh MSSR. Trudy Odesskogo Universiteta. Sbornik Geologo-Geograficheskogo Fakul'teta 2: 109-119.

Jordan, D.S., and B.W. Evermann. 1896. The fishes of North and Middle America: a descriptive catalogue of the species of fish-like vertebrates found in the waters of North America, North of the Isthmus of Panama Part I. Bulletin of the United States National Museum 47: 1-1240.

Kindermann, G., N. Miljković, H. Ahnelt, and D.E. Stevenson. 2007. The osteology of Eucyclogobius newberryi and Quietula guaymasiae (Teleostei: Gobiidae), two closely related Gobionellines from the East Pacific. Annalen des Naturhistorischen Museums in Wien (B: Botanik und Zoologie) 108: 13-56.

Koken, E. 1891. Neue Untersuchungen an tertiären Fisch-Otolithen II. Zeitschrift der deutschen geologischen Gesellschaft 43: 77-170.

Kováč, M., N. Hudáčková, E. Halásová, M. Kováčová, K. Holcová, M. Oszczypko-Clowes, K. Báldi, G. Less, A. Nagymarosy, A. Ruman, T. Klučiar, and M. Jamrich. 2017. The Central Paratethys palaeoceanography: a water circulation model based on microfossil proxies, climate, and changes of depositional environment. Acta Geologica Slovaca 9(2): 75-114.

Kovačić, M. 2008. The key for identification of Gobiidae (Pisces: Perciformes) in the Adriatic Sea. Acta Adriatica 49(3): 245-254.

Kovačić, M., and U.K. Schliewen. 2008. A new species of Gorogobius (Perciformes: Gobiidae) from São Tomé Islands. Zootaxa 1686: 29-36.

Kovačić, M., S.V. Bogorodskii, and A.O. Mal. 2014. Two new species of Coryogalops (Perciformes: Gobiidae) from the Red Sea. Zootaxa 3881(6): 513-531. https://doi.org/10.11646/zootaxa. 3881.6.2.

Kramer, A., M. Kovačić, and R.A. Patzner. 2012. Dentition of eight species of Mediterranean Sea Gobiidae: Do dentition characters of gobies reflect phylogenetic relationships? Journal of Fish Biology 80(1): 29-48. https://doi.org/10.1111/j.1095-8649.2011. 03137.x.

La Mesa, M. 1999. Age and growth of Aphia minuta (Pisces, Gobiidae) from the central Adriatic Sea. Scientia Marina 63(2): 147-155. https://doi.org/10.3989/scimar.1999.63n2147.

La Mesa, M., E. Arneri, V. Caputo, and M. Iglesias. 2005. The transparent goby, Aphia minuta: review of biology and fisheries of a paedomorphic European fish. Reviews in Fish Biology and Fisheries 15(1-2): 89-109. https://doi.org/10.1007/s11160-005-1613-4.

Landau, B.M., M. Harzhauser, Y. İslamoğlu, and C. Marques da Silva. 2013. Systematics and palaeobiogeography of the gastropods of the middle Miocene (Serravallian) Karaman Basin of Turkey. Cainozoic Research 11-13: 3-576.

Larson, H.K. 2001. A revision of the gobiid fish genus Mugilogobius (Teleostei: Gobioidei), and its systematic placement. Records of the Western Australian Museum Supplement 62: 1-233. https:// doi.org/10.18195/issn.0313-122x.62.2001.001-233.

Larson, H.K. 2009. Review of the gobiid fish genera Eugnathogobius and Pseudogobiopsis (Gobioidei: Gobiidae: Gobionellinae), with descriptions of three new species. Raffles Bulletin of Zoology 57(1): 127-181.

Larson, H.K., and D.J. Buckle. 2012. A revision of the goby genus Gnatholepis Bleeker (Teleostei, Gobiidae, Gobionellinae), with description of a new species. Zootaxa 3529(1): 1-69.

Larson, H.K., E.O. Murdy, and A.C. Gill. 2001. Suborder Gobioidei. In The living marine resources of the Western Central Pacific. Volume 6. Bony fishes part 4 (Labridae to Latimeriidae), estuarine crocodiles, sea turtles, sea snakes and marine mammals, eds. K.E. Carpenter and V.H. Niem, 3574-3609. Rome: Food and Agriculture Organization of the United Nations (FAO).
Lin, C.-H., A. Girone, and D. Nolf. 2015. Tortonian fish otoliths from turbiditic deposits in Northern Italy: taxonomic and stratigraphic significance. Geobios 48(3): 249-261. https://doi.org/10.1016/j. geobios.2015.03.003.

Lin, C.-H., R. Brzobohatý, D. Nolf, and A. Girone. 2017. Tortonian teleost otoliths from northern Italy: taxonomic synthesis and stratigraphic significance. European Journal of Taxonomy 322: 1-44. https://doi.org/10.5852/ejt.2017.322.

Liu, H.T.H., H. Ahnelt, G.A.C. Balma, and G.B. Delmastro. 2009. First record of Gobius roulei (Gobiidae) in the Ligurian Sea. Cybium 33(3): 253-254.

Lombarte, A., M. Miletić, M. Kovačić, J.L. Otero-Ferrer, and V.M. Tuset. 2018. Identifying sagittal otoliths of Mediterranean Sea gobies: variability among phylogenetic lineages. Journal of Fish Biology 92(6): 1768-1787. https://doi.org/10.1111/jfb.13615.

Malm, A.W. 1874. Om de Svenske gobiider. Förhandlingar Vid De Skandinaviske Naturforskarnes 11: 380-386.

Maugé, L.A. 1986. Gobiidae. In Check-list of the freshwater fishes of Africa Volume II, eds. J. Daget, J.-P. Gosse, and D.F.E. Thys van den Audenaerde, 358-388. Bruxelles: ISNB, Tervuren: MRAC, and Paris: ORSTOM.

Maul, G.E. 1971. On a new goby of the genus Lesueurigobius from off the Atlantic coast of Morocco and Madeira (Percomorphi, Gobioidea, Gobiidae). Bocagiana 29: 1-7.

McKay, S.I., and P.J. Miller. 1997. The affinities of European sand gobies (Teleostei: Gobiidae). Journal of Natural History 31(10): 1457-1482. https://doi.org/10.1080/00222939700770791.

Miller, P.J. 1973. The osteology and adaptive features of Rhyacichthys aspro (Teleostei: Gobioidei) and the classification of gobioid fishes. Journal of Zoology 171(3): 397-434. https://doi.org/10. 1111/j.1469-7998.1973.tb05347.x.

Miller, P.J. 1986. Gobiidae. In Fishes of the north-eastern Atlantic and the Mediterranean (FNAM), eds. P.J.P. Whitehead, M.-L. Bauchot, J.-C. Hureau, J. Nielsen, and E. Tortonese, 1019-1085. Paris: UNESCO.

Miller, P.J. 2004. The freshwater fishes of Europe. Vol. 8/II. Gobiidae 2. Wiebelsheim: AULA

Miller, P.J., and R. Šanda. 2008. A new West Balkanian sand-goby (Teleostei: Gobiidae). Journal of Fish Biology 72(1): 259-270. https://doi.org/10.1111/j.1095-8649.2007.01709.x.

Miller, P.J., and S. Stefanni. 2001. The Eastern Pacific species of Bathygobius (Perciformes: Gobiidae). Revista de Biología Tropical 49: $141-156$

Müller, J. 1845. Über den Bau und die Grenzen der Ganoiden, und über das natürliche System der Fische. Physikalisch-Mathematische Abhandlungen der königlichen Akademie der Wissenschaften zu Berlin 1845: 117-216.

Murdy, E.O. 1989. A taxonomic revision and cladistic analysis of the oxudercine gobies (Gobiidae: Oxudercinae). Records of the Australian Museum, Supplement 11: 1-93. https://doi.org/10.3853/j. 0812-7387.11.1989.93.

Murdy, E.O., D.F. Hoese, and C.E. Thacker. 2002. Suborder Gobioidei. In The living marine resources of the Western Central Atlantic. Volume 3: Bony fishes part 2 (Opistognathidae to Molidae), sea turtles and marine mammals, ed. K.E. Carpenter, 1778-1798. FAO Species Identification Guide for Fishery Purposes and American Society of Ichthyologists and Herpetologists Special Publication No. 5. Rome: Food and Agriculture Organization of the United Nations.

Nelson, J.S., T.C. Grande, and M.V.H. Wilson. 2016. Fishes of the world, 5th ed. Hoboken: Wiley.

Nolf, D. 1985. Handbook of paleoichthyology, Volume 10, Otolithi piscium. In Handbook of Paleoichthyology, ed. H.-P. Schultze. München: F. Pfeil.

Nolf, D. 2013. The diversity of fish otoliths, past and present. Brussels: Royal Belgian Institute of Natural Sciences. 
Nolf, D., and R. Brzobohatý. 1994. Fish otoliths from the Late Oligocene (Eger and Kiscell Formations) in the Eger area (northeastern Hungary). Bulletin de l'institut Royal des Sciences Naturelles de Belgique, Sciences de la Terre 64: 225-252.

Olivar, M.P. 1989. Spawning and development of Lesueurigobius sanzoi off northern Namibia. African Zoology 24(2): 132-138.

Paghida, N. 1962. Otolitele din Buglovianul Podişului Moldovenesc. Analele Universităţii Bucureşti (Seria ştiinţele naturii) 8: 13-20.

Paghida-Trelea, N., T. Simionescu, and L. Olaru. 1967. Contributii la studiul micropaleontologie al Sarmatianului din imprejurimile Harlaului. Analele Universităţii Bucureşti (Seria ştiinţele naturii: Geologie - geografie) 13: 83-99.

Pallas, P.S. 1770. Spicilegia Zoologica quibus novae imprimis et obscurae animalium species iconibus, descriptionibus atque commentariis illustrantur. Volume 8. Berolini (=Berlin): G.A. Lange.

Pallas, P.S. 1814. Zoographia Rosso-Asiatica, sistens omnium animalium in extenso Imperio Rossico et adjacentibus maribus observatorum recensionem, domicilia, mores et descriptiones anatomen atque icones plurimorum, vol. 3. Sankt Petersburg: Academia Scientiarum.

Penk, S.B.R., M. Altner, A.F. Cerwenka, U.K. Schliewen, and B. Reichenbacher. 2019. New fossil cichlid from the middle Miocene of East Africa revealed as oldest known member of the Oreochromini. Scientific Reports 9: 10198. https://doi.org/10. 1038/s41598-019-46392-5.

Pezold, F. 1993. Evidence for a monophyletic Gobiinae. Copeia 1993(3): 634-643. https://doi.org/10.2307/1447224.

Pezold, F. 2004. Phylogenetic analysis of the genus Gobionellus (Teleostei: Gobiidae). Copeia 2004(2): 260-280. https://doi.org/10. 1643/CI-02-218R3.

Pezold, F.L., and H.K. Larson. 2015. A revision of the fish genus Oxyurichthys (Gobioidei: Gobiidae) with descriptions of four new species. Zootaxa 3988(1): 1-95. https://doi.org/10.11646/ zootaxa.3988.1.1.

Piller, W.E., and M. Harzhauser. 2005. The myth of the brackish Sarmatian Sea. Terra Nova 17(5): 450-455. https://doi.org/10. 1111/j.1365-3121.2005.00632.x.

Pisera, A. 1996. Miocene Reefs of the Paratethys: A Review. In Models for Carbonate Stratigraphy from Miocene Reef Complexes of Mediterranean Region. SEPM concepts in Sedimentology and Paleontology 5: 97-104.

Pobedina, V.M. 1954. Iskopayemye otolity ryb miotsenovykh otlozheniy Azerbaydzhana i ikh stratigraficheskoye znacheniye. Izvestiya Akademii Nauk Azerbaydzhanskoy SSR 10: 23-37.

Pobedina, V.M., A.G. Voroshilova, O.I. Rybina, and Z.V. Kuznetsova. 1956. Spravochnik po mikrofaune sredne- $i$ verkhnemiocenovykh otlozhenii Azerbaidjana (Handbook about microfauna Middle and Upper Miocene deposits of Azerbaijan). Baku: Azerbaidjanskoe gosudarstvennoe izdatelstvo neftyanoi nauchno-tekhnicheskoy literatury.

Popov, Y.A. 2017. First Record of the Pipefish Nerophis zapfei Bachmayer (Syngnathidae, Gasterosteiformes) from the Middle Miocene of Northern Moldova. Paleontological Journal 51(5): 533-541.

Popov, S.V., F. Rögl, A.Y. Rozanov, F.F. Steininger, I.G. Shcherba, and M. Kováč. 2004. Lithological-palaeogeographic maps of Paratethys. 10 Maps Late Eocene to Pliocene. Courier Forschungsinstitut Senckenberg 250: 1-46.

Přikryl, T., R. Brzobohatý, and R. Gregorová. 2016. Diversity and distribution of fossil codlets (Teleostei, Gadiformes, Bregmacerotidae): Review and commentary. Palaeobiodiversity and Palaeoenvironments 96(1): 13-39. https://doi.org/10.1007/ s12549-015-0222-z.

Rado, G. 1968. Étude des otolithes sarmatiens de Copăcel-Chijic (Bassin du Crișul Repede). Travaux du Muséum National d'Histoire Naturelle "Grigore Antipa" 8(3): 581-585.
Radwańska, U. 1992. Fish otoliths in the Middle Miocene (Badenian) deposits of southern Poland. Acta Geologica Polonica 42(3-4): 141-328.

Raffi, I., B.S. Wade, and H. Pälike. 2020. The Neogene Period. In Geologic time scale 2020, vol. 2, eds. F.M. Gradstein, J.G. Ogg, M.D. Schmitz, and G.M. Ogg, 1141-1215. Amsterdam: Elsevier.

Randall, J.E., and D.W. Greenfield. 2001. A preliminary review of the Indo-Pacific gobiid fishes of the genus Gnatholepis. Ichthyological Bulletin of the J.L.B Smith Institute of Ichthyology 69: 1-17.

Reichenbacher, B. 1998. Fisch-Otolithen aus dem Karpat des Korneuburger Beckens. Beiträge zur Paläontologie Österreichs 23: 325-345.

Reichenbacher, B., and H. Cappetta. 1999. First evidence of an early Miocene marine teleostean fish fauna (otoliths) from La Paillade (Montpellier, France). Palaeovertebrata 28(1): 1-46.

Reichenbacher, B., R. Gregorová, K. Holcová, R. Šanda, J. Vukić, and T. Přikryl. 2018. Discovery of the oldest Gobius (Teleostei, Gobiiformes) from a marine ecosystem of Early Miocene age. Journal of Systematic Palaeontology 16(6): 493-513. https://doi. org/10.1080/14772019.2017.1313323.

Reichenbacher, B., S. Filipescu, and A. Miclea. 2019. A unique middle Miocene (Sarmatian) fish fauna from coastal deposits in the eastern Pannonian Basin (Romania). Palaeobiodiversity and Palaeoenvironments 99(2): 177-194. https://doi.org/10.1007/ s12549-018-0334-3.

Reichenbacher, B., T. Přikryl, A.F. Cerwenka, P. Keith, C. Gierl, and M. Dohrmann. 2020. Freshwater gobies 30 million years ago: new insights into character evolution and phylogenetic relationships of $†$ Pirskeniidae (Gobioidei, Teleostei). PLoS ONE 15(8): e0237366. https://doi.org/10.1371/journal.pone.0237366.

Risso, A. 1810. Ichthyologie de Nice, ou histoire naturelle des poissons du Département des Alpes Maritimes. Paris: F. Schoell.

Rojo, A.L. 1985. Osteología del chanquete, Aphya minuta (Risso, 1810) (Pisces: Gobiidae). Boletín del Instituto Español de Oceanografía 2(1): 165-179.

Roşca, V.H. 2008. The modern interpretation of the Sarmatian basin history and its significance for stratigraphy. In Biostratigraphic fundamentals of creating the stratigraphic schemes of the Phanerozoic of Ukraine, ed. P.F. Gozhik. Proceedings of the Institute of Geological Sciences of the NAS of Ukraine, 420-423. Kyiv.

Schneider, C.A., W.S. Rasband, and K.W. Eliceiri. 2012. NIH image to ImageJ: 25 years of image analysis. Nature Methods 9(7): 671-675. https://doi.org/10.1038/nmeth.2089.

Schultz, O. 2013. Catalogus Fossilium Austriae, vol. 3: Pisces. Wien: Österreichische Akademie der Wissenschaften.

Schulz-Mirbach, T., and M. Plath. 2012. All good things come in threes-species delimitation through shape analysis of saccular, lagenar and utricular otoliths. Marine and Freshwater Research 63(10): 934-940. https://doi.org/10.1071/mf12132.

Schulz-Mirbach, T., and B. Reichenbacher. 2006. Reconstruction of Oligocene and Neogene freshwater fish faunas-an actualistic study on cypriniform otoliths. Acta Palaeontologica Polonica 51(2): 283-304.

Schwarzhans, W. 2014. Otoliths from the middle Miocene (Serravallian) of the Karaman Basin, Turkey. Cainozoic Research 14(1): 35-69.

Schwarzhans, W. 2017. A review of otoliths collected by W. Weiler from the Badenian of Romania and by B. Strashimirov from Badenian equivalents of Bulgaria. Cainozoic Research 17(2): 167-191.

Schwarzhans, W., R.P. Scofield, A.J.D. Tennyson, J.P. Worthy, and T.H. Worthy. 2012. Fish remains, mostly otoliths, from the nonmarine early Miocene of Otago, New Zealand. Acta Palaeontologica Polonica 57(2): 319-350. https://doi.org/10.4202/app. 2010.0127 
Schwarzhans, W., K. Bradić, and L. Rundić. 2015. Fish-otoliths from the marine-brackish water transition from the Middle Miocene of the Belgrade area, Serbia. Paläontologische Zeitschrift 89(4): 815-837. https://doi.org/10.1007/s12542-015-0272-6.

Schwarzhans, W., H. Ahnelt, G. Carnevale, S. Japundžić, K. Bradić, and A. Bratishko. 2017a. Otoliths in situ from Sarmatian (Middle Miocene) fishes of the Paratethys. Part III: tales from the cradle of the Ponto-Caspian gobies. Swiss Journal of Palaeontology 136(1): 45-92. https://doi.org/10.1007/s13358-016-0120-7.

Schwarzhans, W., G. Carnevale, A.F. Bannikov, S. Japundžić, and K. Bradić. 2017b. Otoliths in situ from Sarmatian (Middle Miocene) fishes of the Paratethys. Part I: Atherina suchovi Switchenska, 1973. Swiss Journal of Palaeontology 136(1): 7-17. https://doi. org/10.1007/s13358-015-0111-0.

Schwarzhans, W., G. Carnevale, A. Bratishko, S. Japundžić, and K. Bradić. 2017c. Otoliths in situ from Sarmatian (Middle Miocene) fishes of the Paratethys. Part II: Gadidae and Lotidae. Swiss Journal of Palaeontology 136(1): 19-43. https://doi.org/10.1007/ s13358-016-0114-5.

Schwarzhans, W., G. Carnevale, S. Japundzic, and K. Bradic-Milinovic. 2017d. Otoliths in situ from Sarmatian (Middle Miocene) fishes of the Paratethys. Part IV: Scorpaenidae, Labridae, and Gobiesocidae. Swiss Journal of Palaeontology 136(1): 93-108. https:// doi.org/10.1007/s13358-017-0124-y.

Schwarzhans, W., G. Carnevale, S. Japundžić, and K. Bradić-Milinović. 2017e. Otoliths in situ from Sarmatian (Middle Miocene) fishes of the Paratethys. Part V: Bothidae and Soleidae. Swiss Journal of Palaeontology 136(1): 109-127. https://doi.org/10.1007/ s13358-017-0128-7.

Schwarzhans, W., K. Agiadi, and G. Carnevale. 2020a. Late MioceneEarly Pliocene evolution of Mediterranean gobies and their environmental and biogeographic significance. Rivista Italiana di Paleontologia e Stratigrafia 126(3): 657-724.

Schwarzhans, W., R. Brzobohatý, and U. Radwanska. 2020b. Goby otoliths from the Badenian (middle Miocene) of the Central Paratethys from the Czech Republic, Slovakia and Poland: A baseline for the evolution of the European Gobiidae (Gobiiformes; Teleostei). Bollettino della Società Paleontologica Italiana 59(2): 125-173. https://doi.org/10.4435/bspi.2020.10.

Shibukawa, K., and A. Iwata. 2007. Grallenia, a new goby genus from the western Pacific, with descriptions of two new species (Perciformes: Gobiidae: Gobiinae). Bulletin of the National Museum of Nature and Science (Series A), Supplement 1: 123-136.

Skutschas, P.P., and A.F. Bannikov. 2009. The first find of a spadefoot toad (Anura, Pelobatidae) in the Miocene of Moldova. Paleontological Journal 43(4): 433-437. https://doi.org/10.1134/s0031 030109040121.

Starks, E.C. 1913. The fishes of the Stanford expedition to Brazil. Leland Stanford Jr. University Publications, University Series. Stanford: Stanford University.

Steindachner, F. 1860. Beiträge zur Kenntniss der fossilen Fischfauna Österreichs. (Dritte Folge.). Sitzungsberichte der Kaiserlichen Akademie der Wissenschaften in Wien. Mathematisch-naturwissenschaftliche Classe 40(12): 555-572.

Steurbaut, E. 1984. Teleostean otoliths from the Oligo-Miocene from Aquitaine Southwestern France. Palaeontographica (A: Paläozoologie, Stratigraphie) 186(1-6): 1-162.

Strashimirov, B. 1984. Otolity ot dolnia sarmat na Severnaia Bulgaria. Palaeontology, Stratigraphy and Lithology 20(15): 15-41.

Strashimirov, B. 1985a. Otolity ot gornia sarmat na Severozapadna Bulgaria. Annual of the Highest Institute of Mining and Geology Sofia 31: 21-36.

Strashimirov, B. 1985b. Otolity ot srednia sarmat na Severnaia Bulgaria. Annual of the Highest Institute of Mining and Geology Sofia 31: 7-20.
Studencka, B. 1986. Bivalves from the Badenian (Middle Miocene) marine sandy facies of southern Poland. Palaeontologia Polonica 47: $1-128$.

Switchenska, A.A. 1959a. Iskopaemij predstavitelj semejstva Mullidae. Materialy k "osnovam Paleontologii" 3: 117-118. (in Russian).

Switchenska, A.A. 1959b. Mullet from the Sarmatian of Moldavia. Paleontologicheskii Zhurnal 1959(1):: 98-99. (in Russian).

Switchenska, A.A. 1973. Fossil mugiliforms of the USSR. Trudy Paleontologiceskogo Instituta Akademii Nauk SSSR 138: 1-64. (in Russian).

Thacker, C.E. 2009. Phylogeny of Gobioidei and placement within Acanthomorpha, with a new classification and investigation of diversification and character evolution. Copeia 2009(1): 93-104. https://doi.org/10.1643/Ci-08-004.

Thacker, C.E. 2013. Phylogenetic placement of the European sand gobies in Gobionellidae and characterization of gobionellid lineages (Gobiiformes: Gobioidei). Zootaxa 3619(3): 369-382.

Thacker, C.E. 2015. Biogeography of goby lineages (Gobiiformes: Gobioidei): origin, invasions and extinction throughout the Cenozoic. Journal of Biogeography 4(9): 1615-1625. https://doi.org/ 10.1111/jbi.12545.

Thacker, C.E., T.P. Satoh, E. Katayama, R.C. Harrington, R.I. Eytan, and T.J. Near. 2015. Molecular phylogeny of Percomorpha resolves Trichonotus as the sister lineage to Gobioidei (Teleostei: Gobiiformes) and confirms the polyphyly of Trachinoidei. Molecular Phylogenetics and Evolution 93: 172-179. https://doi. org/10.1016/j.ympev.2015.08.001.

Tornabene, L., C.C. Baldwin, L.A. Weigt, and F.L. Pezold. 2010. Exploring the diversity of western Atlantic Bathygobius (Teleostei: Gobiidae) with cytochrome c oxidase-I, with descriptions of two new species. Aqua. International Journal of Ichthyology 16(4): 141-170.

Vahed, N.S., H.R. Esmaeili, M. Masoudi, and B. Reichenbacher. 2018. Early otolith development in the critically endangered tooth-carp, Aphanius farsicus (Teleostei: Cyprinodontidae). Environmental Biology of Fishes 101(9): 1309-1317. https://doi.org/10.1007/ s10641-018-0778-3.

Vahed, N.S., H.R. Esmaeili, M. Masoudi, and B. Reichenbacher. 2019. Ontogenetic Otolith Development in an Endemic Tooth-Carp, Aphanius vladykovi (Teleostei: Aphaniidae). Journal of Ichthyology 59(3): 336-343. https://doi.org/10.1134/s00329452190301 72.

Vasil'eva, E.D. 1983. Osteological analysis of some Caspian gobies in connection with the taxonomy of the genus Benthophilus (Gobiidae). Voprosy Ikhtiologii 23(4): 544-556.

Vasil'eva, E.D. 1999. Taxonomic status of the tube-nose goby Gobius marmoratus Pallas (Gobiidae) based on its skull morphology. Journal of Ichthyology 39(2): 139-148.

Vasil'eva, E.D. 2007. Gobies of the Genus Rhinogobius (Gobiidae) from Primor'e and Water Bodies of Central Asia and Kazakhstan: I. Morphological Characteristic and Taxonomic Status. Journal of Ichthyology 47(9): 691-700. https://doi.org/10.1134/ S0032945208010037.

Vasil'eva, E.D., and S.V. Bogorodskii. 2004. Two new species of gobies (Gobiidae) in the ichthyofauna of the Black Sea. Journal of Ichthyology 44(8): 555-562.

Vasil'eva, E.D., and T.I. Kuga. 2008. Gobies of the genus Rhinogobius (Gobiidae) of primorye and the water bodies of Central Asia and Kazakhstan: II Comparative craniological analysis of gobies introduced to Central Asia. Journal of Ichthyology 48(1): 29-36. https://doi.org/10.1134/S0032945208010037.

Vasil'eva, E.D., and V.P. Vasil'ev. 2016. Morphological variability, chromosome polymorphism, and problems of identifying individual species of gobies of the group Ponticola (Gobiidae) and assessing taxonomic relations of local populations. Journal of 
Ichthyology 56(5): 644-655. https://doi.org/10.1134/s003294521 6050143.

Wang, H.-Y., M.-P. Tsai, J. Dean, and S.-C. Lee. 2001. Molecular phylogeny of gobioid fishes (Perciformes: Gobioidei) based on mitochondrial $12 \mathrm{~S}$ rRNA sequences. Molecular Phylogenetics and Evolution 20(3): 390-408. https://doi.org/10.1006/mpev. 2001.0957.

Watson, R.E. 1991. A provisional review of the genus Stenogobius with descriptions of a new subgenus and thirteen new species. (Pisces: Teleostei: Gobiidae). Records of the Western Australian Museum 15: 571-654.

Weiler, W. 1943. Die Otolithen aus dem Jungtertiär Süd-Rumäniens. 1. Buglow und Sarmat. Senckenbergiana 26(1/3): 87-115.
Weiler, W. 1949. Die Otolithen aus dem Jung-Tertiär Süd-Rumäniens. 1b. Ergänzende Tafeln zu den Otolithen des Buglow und Sarmat. Senckenbergiana 30(4/6): 291-293.

Whitley, G.P. 1950. New fish names. Proceedings of the Royal Society of New South Wales 1948-49: 44.

Yakubovskaya, T.A. 1955. The Sarmatian Flora of the Moldavian SSR. In Flora and systematics of higher plants, ed. B.K. Shishkin. Transactions of the Botanical Institute (Series 1) 11: 7-109.

Zachos, J., M. Pagani, L. Sloan, E. Thomas, and K. Billups. 2001. Trends, rhythms, and aberrations in global climate $65 \mathrm{Ma}$ to present. Science 292(5517): 686-693. https://doi.org/10.1126/ science.1059412. 